\title{
Chemical Biodiversity and Bioactivities of Saponins in Echinodermata with an Emphasis on Sea Cucumbers (Holothuroidea)
}

\author{
Elham Kamyab, Matthias Y. Kellermann, \\ Andreas Kunzmann, and Peter J. Schupp
}

\begin{abstract}
Echinoderms are a source of a broad range of secondary metabolites with a large variety of bioactive properties. Although pigment and lipid derivatives are the major groups of bioactive compounds found in crinoids and ophiuroids, saponins represent the most abundant and diverse marine natural products (MNPs) in the phylum Echinodermata. This review is for researchers that are interested in MNPs derived from echinoderms, but with a particular focus on the structural diversity and biological function of saponins. Among the echinoderms, these steroidal compounds are mostly known for and structurally most diverse within sea cucumbers. Through compilation of extensive tables, this review provides a reference book, summarizing not only the major chemical classes of well-known secondary metabolites in the phylum Echinodermata but also further focusing on the presence of bioactive saponins in echinoderms in general and within different sea cucumber species in particular. The final compilation aims to correlate the vast structural diversity of saponins with known biological functions. The here presented data revealed that holothurians, holotoxins, cucumariosides, and echinosids are not only the most abundant saponin compounds in various genera of sea cucumbers but that these saponins can also be used as potential chemotaxonomic markers for different sea cucumber
\end{abstract}

E. Kamyab $(\varangle) \cdot$ M. Y. Kellermann

Institute of Chemistry and Biology of the Marine Environment, University of Oldenburg, Oldenburg, Germany

e-mail: elham.kamyab@uni-oldenburg.de

A. Kunzmann

Leibniz Centre for Tropical Marine Research (ZMT) GmbH,

Bremen, Germany

Faculty 02, University of Bremen, Bremen, Germany

P. J. Schupp ( $\square)$

Institute of Chemistry and Biology of the Marine Environment, University of Oldenburg, Oldenburg, Germany

Helmholtz Institute for Functional Marine Biodiversity at the University of Oldenburg (HIFMB), Oldenburg, Germany species. By studying the structure-function relationships of triterpene glycosides in echinoderms in general, or in particular within holothurians, the vast structural diversity, taxonomic distribution, and bioactivity of the molecules can be deciphered, which provides an opportunity to focus future research efforts on target species that contain MNPs with novel pharmacological activities.

\section{Keywords}

Secondary metabolites Chemical diversity $\cdot$ Taxonomic markers $\cdot$ Structure-function analysis $\cdot$ Saponins ·

Echinoderms $\cdot$ Sea cucumber

\subsection{Marine Natural Products (MNPs)}

Compared to synthesized organic compounds, natural products (NPs) have long been used as efficient and often less harmful sources of drug molecules (Molinski et al. 2009). NPs refer to both primary and secondary metabolites; however, in the past, research on secondary metabolites mostly described ecological interactions of organisms with their environment, the pronounced biological and pharmacological activities, their great chemical diversity, and their higher tendency to interact with other biologically relevant molecules (Croteau et al. 2000).

The marine environment came into the focus of NPs right after technologies for studying marine ecosystems improved. Since the early 1900s, the idea of utilizing marine ecosystems as the potentially largest source for marine natural products (hereafter MNPs) was shaped. Although research on MNPs dates back more than 50 years and more than 32,000 studies related to MNPs have been published (MarineLit; http://pubs. rsc.org/marinlit/), only a few marine-derived compounds resulted in clinical trials (Mayer et al. 2017). That is, from 52 marine invertebrate-derived compounds that reached clinical trials, only seven compounds, isolated from sponges, mollusks, tunicates, and their associated bacteria, have so far 
been approved. Unfortunately, 45 of the total 52 MNPs have been discontinued from clinical trials (Fig. 7.1) due to low production yields and/or high costs.

In this review, we provide an overview on the MNPs reported from echinoderms with an emphasis on MNPs (i.e., particularly triterpene glycosides) reported from shallow water sea cucumbers. While there is extensive literature on the chemistry of MNPs from sessile marine organisms such as sponges, ascidians, and corals, MNP data on slow-moving invertebrates such as echinoderms are much more limited. Up to now, more than 7,000 living echinoderms species, divided into three subphyla and five different classes, have been described (Fig. 7.2). The evolutionary divergence of echinoderms with chordates rather than invertebrates makes their biochemistry and physiology rather similar with vertebrates. They can synthesize vertebrate-type steroids, which regulate their reproductive, growth, and developmental processes (Schoenmakers 1979). Therefore, it can be hypothesized that echinoderms can be promising substitution candidates of the synthetic compounds for producing efficient secondary metabolites helpful for human health. Although several defense mechanisms such as presence of spine, cuvierian tubules (CTs), evisceration, toxic secretion, and unpalatability are generally described for echinoderms and particularly for holothurians, they do not have a significant escape behavior and therefore likely depend on chemical defense strategies, such as triterpene glycosides, to protect themselves against predators (Iyengar and Harvell 2001; Bahrami et al. 2016). Saponins represent a diverse group of triterpene glycosides that have been mainly described from plants and are also one of the major secondary metabolite classes in Echinodermata including holothurians. Saponins are promising MNPs with the capacity to influence physiological and immunological processes and thus have been implicated as bioactive compounds in many ecological studies (Kalinin et al. 1996; Francis et al. 2002). In the following sections, we will discuss in more detail the role of saponins and other bioactive compounds in echinoderms in general, however, with a major focus on sea cucumbers.

\subsection{MNPs in Echinoderms}

From 28,609 MNPs that have been reported until 2016, more than $35 \%$ of the total compounds were isolated from echinoderms. However, the reported chemical diversity of MNPs from echinoderms, compared to other phyla, was not high (Blunt et al. 2018).

Typical reported MNPs derived from echinoderms are sulfated compounds that can be largely classified into two major groups: aromatics and saponins. Among the five classes of echinoderms (Fig. 7.2), aromatic sulfated compounds have only been reported in crinoids and ophiuroids as pigments derived from anthraquinones or naphthoquinones, whereas most of the saponins have been isolated from asteroids, echinoids, and holothuroids (Kornprobst et al. 1998) (Tables 7.1 and 7.2). Among various types of secondary metabolites that have been isolated a: 1950s-2010

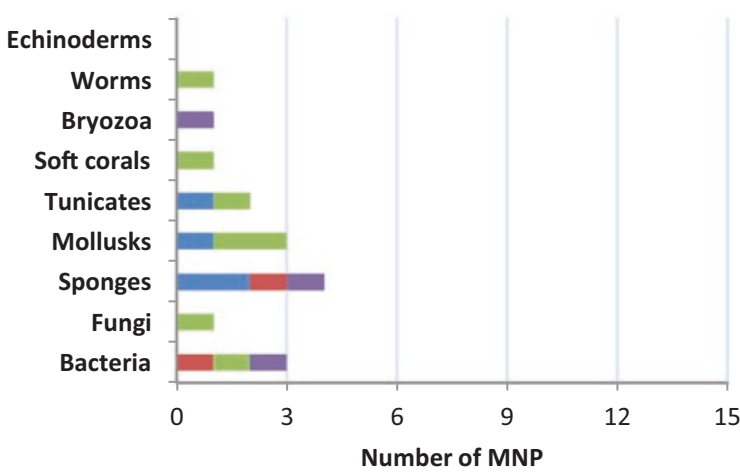

b: $2010-2018$

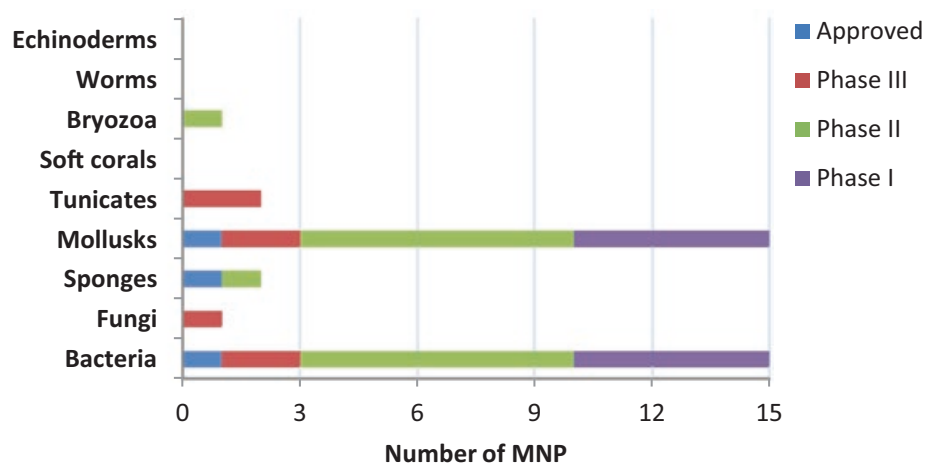

Fig. 7.1 Overview of marine organisms from which MNPs entered the pharmaceutical pipeline (a) from 1950s to 2010 and (b) from 2010 to 2018 . (Compiled with data from Mayer and Hamann 2002; Mayer et al. 2017; http://marinepharmacology.midwestern.edu)

Fig. 7.2 Phylogenetic tree for the phylum Echinodermata (modified after Telford et al. 2014)

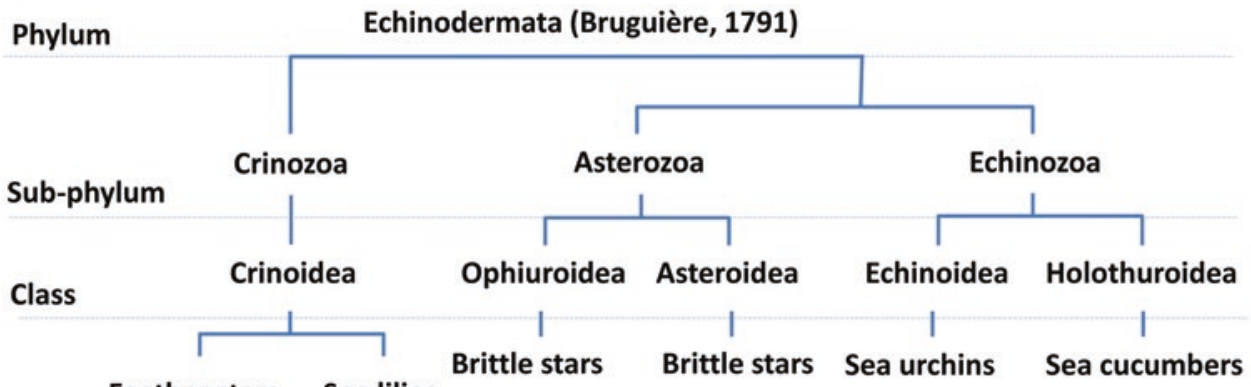

Feather stars Sea lilies 
Table 7.1 Classes of echinoderms, major classes of secondary metabolites, examples of compounds, their bioactivity, and example species for which the compounds have been reported

\begin{tabular}{|c|c|c|c|c|c|}
\hline & $\begin{array}{l}\text { Major classes of } \\
\text { secondary metabolites }\end{array}$ & $\begin{array}{l}\text { Examples of bioactive } \\
\text { compounds }\end{array}$ & Biological activity & Example of organisms & References \\
\hline \multirow[t]{4}{*}{$\begin{array}{l}\text { Crinoids: Lipids, } \\
\text { pigments, polyketides }\end{array}$} & Polyketides & $\begin{array}{l}\text { Rhodoptilometrin, } \\
\text { crinemodin }\end{array}$ & Antipredatory & *Comanthus bennetti & $\begin{array}{l}\text { Rideout et al. } \\
\text { (1979) }\end{array}$ \\
\hline & Lipids & $\begin{array}{l}\text { Ganglioside, } \\
\text { cerebrosides }\end{array}$ & n.d. & $\begin{array}{l}\text { *Comanthina } \\
\text { schlegelii }\end{array}$ & $\begin{array}{l}\text { Inagaki et al. } \\
(2007)\end{array}$ \\
\hline & Naphthopyrones & $\begin{array}{l}\text { Naphthopyrones } \\
\text { comaparvin }\end{array}$ & Anti-inflammatory & $\begin{array}{l}\text { Comanthus } \\
\text { parvicirrus }\end{array}$ & $\begin{array}{l}\text { Karin et al. } \\
\text { (2004), Folmer } \\
\text { et al. (2009), } \\
\text { Chovolou et al. } \\
\text { (2011), and Chen } \\
\text { et al. (2014) }\end{array}$ \\
\hline & $\begin{array}{l}\text { Anthraquinoid } \\
\text { pigments }\end{array}$ & Gymnochrome D & Antiviral & $\begin{array}{l}\text { *Gymnocrinus } \\
\text { richeri }\end{array}$ & $\begin{array}{l}\text { Laille et al. } \\
\text { (1998) }\end{array}$ \\
\hline \multirow{6}{*}{$\begin{array}{l}\text { Asteroids: Steroidal } \\
\text { derivatives of } \\
\text { cholesterol, fatty } \\
\text { acids, ceramides, and } \\
\text { few alkaloids and } \\
\text { proteins }\end{array}$} & Lipids & Hexadecanoic acid & Antifouling & Linckia laevigata & $\begin{array}{l}\text { Guenther et al. } \\
(2009)\end{array}$ \\
\hline & Lipids & Sphingolipids & n.d. & $\begin{array}{l}\text { Ophidiaster } \\
\text { ophidianus }\end{array}$ & Jin et al. (1994) \\
\hline & Asterosaponins & Thornasteroside A & Antitumor & Asteropsis carinifera & $\begin{array}{l}\text { Malyarenko et al. } \\
\text { (2012) }\end{array}$ \\
\hline & Fatty acids & Eicosanoic acid & n.d. & $\begin{array}{l}\text { Culcita } \\
\text { novaeguineae }\end{array}$ & $\begin{array}{l}\text { Bruno et al. } \\
(1992) \text { and } \\
\text { Inagaki (2008) }\end{array}$ \\
\hline & Protein & Ciguatoxins & n.d. & $\begin{array}{l}\text { Marthasterias } \\
\text { glacialis }\end{array}$ & Silva et al. (2015) \\
\hline & Polyhydroxysteroids & Laeviusculosides & $\begin{array}{l}\text { Hemolytic, cytotoxic } \\
\text { activity }\end{array}$ & Henricia leviuscula & $\begin{array}{l}\text { Ivanchina et al. } \\
(2006) \text { and } \\
\text { Fedorov et al. } \\
(2008)\end{array}$ \\
\hline \multirow{4}{*}{$\begin{array}{l}\text { Ophiuroids: } \\
\text { Carotenoids, } \\
\text { gangliosides, } \\
\text { brominated indoles, } \\
\text { phenyl propanoids, } \\
\text { terpenes, steroids }\end{array}$} & Steroidal glycosides & Steroidal glycosides & Antiviral & $\begin{array}{l}\text { Ophiarachna } \\
\text { incrassata }\end{array}$ & $\begin{array}{l}\text { D'Auria et al. } \\
\text { (1993) }\end{array}$ \\
\hline & Steroidal compound & Polyhydroxysterols & Antiviral & Astrotoma agassizii & $\begin{array}{l}\text { Comin et al. } \\
(1999)\end{array}$ \\
\hline & Terpene & $\begin{array}{l}\text { 2,3-Dimethyl } \\
\text { butenolide }\end{array}$ & Antitumor & Ophiomastix mixta & Lee et al. (2007) \\
\hline & Carotenoid & Ophioxanthin & Antioxidant & $\begin{array}{l}\text { Ophioderma } \\
\text { longicauda }\end{array}$ & $\begin{array}{l}\text { D'Auria et al. } \\
\text { (1985) }\end{array}$ \\
\hline \multirow[t]{6}{*}{$\begin{array}{l}\text { Echinoids: Protein, } \\
\text { polysaccharides, lipid, } \\
\text { pigments }\end{array}$} & $\begin{array}{l}\text { Naphthoquinoid } \\
\text { pigment }\end{array}$ & Echinochrome A & $\begin{array}{l}\text { Antioxidant, } \\
\text { antimicrobial, } \\
\text { anti-inflammatory, } \\
\text { antitoxic agents }\end{array}$ & $\begin{array}{l}\text { *Anthocidaris } \\
\text { crassispina }\end{array}$ & $\begin{array}{l}\text { Berdyshev et al. } \\
\text { (2007) and Jeong } \\
\text { et al. (2014) }\end{array}$ \\
\hline & \multirow[t]{2}{*}{ Peptides } & Strongylostatin & Anticancer & $\begin{array}{l}\text { Strongylocentrotus } \\
\text { droebachiensis }\end{array}$ & Pettit et al. (1981) \\
\hline & & Strongylocins & Antimicrobial & $\begin{array}{l}\text { Strongylocentrotus } \\
\text { droebachiensis }\end{array}$ & Li et al. (2008) \\
\hline & Polysaccharide & Sulfated fucan & Anticoagulant & $\begin{array}{l}\text { Lytechinus } \\
\text { variegatus }\end{array}$ & $\begin{array}{l}\text { Pereira et al. } \\
(1999)\end{array}$ \\
\hline & Steroidal compounds & n.d. & Anticancer & Diadema savignyi & $\begin{array}{l}\text { Thao et al. } \\
(2015 a)\end{array}$ \\
\hline & Ganglioside & DSG-A & Neuritogenic & Diadema setosum & $\begin{array}{l}\text { Yamada et al. } \\
(2008)\end{array}$ \\
\hline
\end{tabular}


Table 7.1 (continued)

\begin{tabular}{|c|c|c|c|c|c|}
\hline & $\begin{array}{l}\text { Major classes of } \\
\text { secondary metabolites }\end{array}$ & $\begin{array}{l}\text { Examples of bioactive } \\
\text { compounds }\end{array}$ & Biological activity & Example of organisms & References \\
\hline \multirow[t]{17}{*}{$\begin{array}{l}\text { Holothuroids: } \\
\text { Triterpene glycosides, } \\
\text { peptides, } \\
\text { polysaccharides, } \\
\text { lipids }\end{array}$} & Triterpene glycoside & Holothurins (A-B) & $\begin{array}{l}\text { Antifungal, anticancer, } \\
\text { ichthyotoxic }\end{array}$ & $\begin{array}{l}\text { Holothuria atra, } \\
\text { Holothuria } \\
\text { fuscocinerea }\end{array}$ & $\begin{array}{l}\text { Yamanouchi } \\
\text { (1955), } \\
\text { Kobayashi et al. } \\
\text { (1991), Popov } \\
\text { et al. (1994), and } \\
\text { Zhang et al. } \\
\text { (2006d) }\end{array}$ \\
\hline & Triterpene glycoside & Echinoside A & Antifungal & Actinopyga echinites & $\begin{array}{l}\text { Kitagawa et al. } \\
\text { (1985) }\end{array}$ \\
\hline & Triterpene glycoside & Holotoxin A-F & $\begin{array}{l}\text { Anticancer, antifungal, } \\
\text { antiprotozoa }\end{array}$ & $\begin{array}{l}\text { Apostichopus } \\
\text { japonicus }\end{array}$ & $\begin{array}{l}\text { Kitagawa et al. } \\
\text { (1976), Anisimov } \\
\text { et al. (1983), } \\
\text { Maltsev et al. } \\
\text { (1985), and Wang } \\
\text { et al. (2012) }\end{array}$ \\
\hline & Triterpene glycosides & Holotoxin & Antifungal & S. japonicus & Yano et al. (2013) \\
\hline & Polysaccharides & $\begin{array}{l}\text { Glucosamine, } \\
\text { Galactosamine }\end{array}$ & $\begin{array}{l}\text { Antihyperlipidemic, } \\
\text { antioxidant }\end{array}$ & A. japonicus & Liu et al. (2012) \\
\hline & $\begin{array}{l}\text { Sulfated } \\
\text { polysaccharides }\end{array}$ & FucCS, GAGs & $\begin{array}{l}\text { Anticoagulant, } \\
\text { antithrombin, } \\
\text { antiparasitic }\end{array}$ & $\begin{array}{l}\text { Ludwigothurea } \\
\text { grisea }\end{array}$ & $\begin{array}{l}\text { Mourão et al. } \\
\text { (1998), Borsig } \\
\text { et al. (2007), and } \\
\text { Marques et al. } \\
\text { (2016) }\end{array}$ \\
\hline & $\begin{array}{l}\text { Sulfated } \\
\text { polysaccharides }\end{array}$ & FucCS & $\begin{array}{l}\text { Anticoagulant, } \\
\text { antithrombin, } \\
\text { antihyperglycemic, } \\
\text { antiviral, } \\
\text { insulin-sensitizing }\end{array}$ & $\begin{array}{l}\text { Thelenota ananas, } \\
\text { Cucumaria frondosa }\end{array}$ & $\begin{array}{l}\text { Borsig et al. } \\
\text { (2007), Huang } \\
\text { et al. (2013), and } \\
\text { Hu et al. (2014a) }\end{array}$ \\
\hline & $\begin{array}{l}\text { Sulfated } \\
\text { polysaccharides }\end{array}$ & FucCS & $\begin{array}{l}\text { Anticoagulant, } \\
\text { antiparasitic }\end{array}$ & $\begin{array}{l}\text { Isostichopus } \\
\text { badionotus }\end{array}$ & $\begin{array}{l}\text { Marques et al. } \\
(2016)\end{array}$ \\
\hline & $\begin{array}{l}\text { Sulfated } \\
\text { polysaccharides }\end{array}$ & GAGs & Antihyperlipidemic & *Metriatyla scabra & Liu et al. (2002) \\
\hline & Fatty acid & $\begin{array}{l}\text { EPA-enriched PL, } \\
\text { 12-MTA, ODAs }\end{array}$ & $\begin{array}{l}\text { Antioxidant, } \\
\text { antihyperglycemic, } \\
\text { anticancer, } \\
\text { antihyperlipidemic }\end{array}$ & $\begin{array}{l}\text { C. frondosa, } \\
\text { Stichopus japonicus }\end{array}$ & $\begin{array}{l}\text { Yang et al. } \\
\text { (2003), Nguyen } \\
\text { et al. 2011, Hu } \\
\text { et al. (2014b), Wu } \\
\text { et al. (2014), and } \\
\text { Ku et al. (2015) }\end{array}$ \\
\hline & Lipid & $\begin{array}{l}\text { Cerebrosides, } \\
\text { galactocerebrosides, } \\
\text { AMC-2 }\end{array}$ & $\begin{array}{l}\text { Anticancer, } \\
\text { antihyperlipidemic }\end{array}$ & $\begin{array}{l}\text { *Stichopus } \\
\text { variegatus, Acaudina } \\
\text { molpadioides, } \\
\text { Bohadschia argus }\end{array}$ & $\begin{array}{l}\text { Sugawara et al. } \\
\text { (2006), Ikeda } \\
\text { et al. (2009), } \\
\text { Zhang et al. } \\
\text { (2012), and Du } \\
\text { et al. (2015) }\end{array}$ \\
\hline & Sphingolipid & Cerebroside & Antioxidant & $\begin{array}{l}\text { S. japonicus, } \\
\text { Acaudina } \\
\text { molpadioides }\end{array}$ & $\begin{array}{l}\text { Duan et al. (2016) } \\
\text { and } \mathrm{Xu} \text { et al. } \\
(2011)\end{array}$ \\
\hline & Lysophospholipid & LPC, L-PAF & Anti-inflammatory & Holothuria atra & $\begin{array}{l}\text { Nishikawa et al. } \\
\text { (2015) }\end{array}$ \\
\hline & Peptide & $\begin{array}{l}\text { Phenoloxidase, } \\
\text { lysozyme }\end{array}$ & Antimicrobial & C. frondosa & $\begin{array}{l}\text { Beauregard et al. } \\
\text { (2001) }\end{array}$ \\
\hline & Peptide & $\begin{array}{l}\text { ACE inhibitory } \\
\text { peptide }\end{array}$ & Antihypertension & $\begin{array}{l}\text { Acaudina } \\
\text { molpadioides }\end{array}$ & Zhao et al. (2009) \\
\hline & Peptide & $\begin{array}{l}\text { T-antigen-binding } \\
\text { lectin }\end{array}$ & Antibacterial & Holothuria scabra & $\begin{array}{l}\text { Gowda et al. } \\
\text { (2008) }\end{array}$ \\
\hline & Phenolic compounds & n.d. & Anti-inflammatory & S. japonicus & Song et al. (2016) \\
\hline
\end{tabular}


Table 7.1 (continued)

\begin{tabular}{|c|c|c|c|c|}
\hline $\begin{array}{l}\text { Major classes of } \\
\text { secondary metabolites }\end{array}$ & $\begin{array}{l}\text { Examples of bioactive } \\
\text { compounds }\end{array}$ & Biological activity & Example of organisms & References \\
\hline Phenolic compounds & (Z)2,3-DPAN & Anticancer & Holothuria parva & $\begin{array}{l}\text { Amidi et al. } \\
\text { (2017) }\end{array}$ \\
\hline Pigments & Carotenoids & Antioxidant & Holothuria atra & $\begin{array}{l}\text { Esmat et al. } \\
(2013)\end{array}$ \\
\hline Pigments & $\begin{array}{l}\beta \text {-carotene, } \\
\text { echinenone, } \\
\text { canthaxanthin, etc. }\end{array}$ & Antioxidant & $\begin{array}{l}\text { Plesiocolochirus } \\
\text { minaeus }\end{array}$ & $\begin{array}{l}\text { Maoka et al. } \\
(2015)\end{array}$ \\
\hline Sulfated alkene & 2,6-DMHS, OS, DS & $\begin{array}{l}\text { Antibacterial, } \\
\text { antifungal }\end{array}$ & A. japonicus & La et al. (2012) \\
\hline Mucopolysaccharide & SJAMP & $\begin{array}{l}\text { Antitumor, } \\
\text { immunomodulatory } \\
\text { effect }\end{array}$ & S. japonicus & Song et al. (2013) \\
\hline \begin{tabular}{|l|} 
Glycolipid/ \\
Sphingolipid \\
\end{tabular} & 2,6-DMHS, OS, DS & Anticancer & A. japonicus & La et al. (2012) \\
\hline Saponin & Frondanol $\mathrm{A}_{5}$ & Anticancer & C. frondosa & $\begin{array}{l}\text { Janakiram et al. } \\
\text { (2010)and Jia } \\
\text { et al. (2016) }\end{array}$ \\
\hline Saponin & n.d. & Antihyperlipidemic & $\begin{array}{l}\text { Pearsonothuria } \\
\text { graeffei }\end{array}$ & $\begin{array}{l}\text { Hu et al. (2010) } \\
\text { and Wu et al. } \\
(2015)\end{array}$ \\
\hline $\begin{array}{l}\text { Monosulfated } \\
\text { triterpene glycosides }\end{array}$ & Cumaside & Radioprotective & Cucumaria japonica & $\begin{array}{l}\text { Aminin et al. } \\
(2011)\end{array}$ \\
\hline
\end{tabular}

n.d. not defined, EPA-enriched PL eicosapentaenoic acid-enriched phospholipids, FucCS fucosylated chondroitin sulfate, GAGs glycosaminoglycan, 2,6-DMHS 2,6-dimethylheptyl sulfate, $O S$ octyl sulfate, $D S$ decyl sulfate, $A C E$ angiotensin I-converting enzyme, $L P C$ lysophosphatidylcholine, $L-P A F$ lyso-platelet activating factor, SCEA-F ethyl acetate solvent fraction of sea cucumber, EPA-enriched PC eicosapentaenoic acid-enriched phosphatidylcholine lipids, 12-MTA 12-methyltetradecanoic acid, (Z)2,3-DPAN (Z)-2,3-diphenylacrylonitrile, SJAMP stichopus japonicus acid mucopolysaccharide, ODAs 7(Z) octadecenoic acid, and 7(Z),10(Z)-octadecadienoic acid

*Based on WoRMS (2019), the accepted names changed from: Metriatyla scabra to Holothuria scabra; Comanthus bennetti to Anneissia bennetti; Comanthina schlegelii to Comaster schlegelii; Gymnocrinus richeri to Neogymnocrinus richeri; Anthocidaris crassispina to Heliocidaris crassispina; Stichopus variegatus to Stichopus horrens

from echinoderms, saponins are the most abundant. Compounds were derived from mainly two classes (i.e., Asteroidea and Holothuroidea) (Haug et al. 2002), which will be discussed in more detail in Sect. 7.3.

\subsubsection{Crinoids (Feather Stars and Sea Lilies)}

The most primitive form of current echinoderms are the crinoids (Karleskint et al. 2010). Sea lilies are, unlike feather stars, sessile and are found mainly in depths $>100 \mathrm{~m}$, whereas feather stars inhabit coral reefs from the intertidal to the deepsea oceans. Moreover, feather stars are physically able to escape from predators by crawling, swimming, or hiding between corals or rocks (Ruppert et al. 2004; Karleskint et al. 2010). Furthermore, crinoids use other physical and chemical defense mechanisms to protect them against fish predators. For example, crinoids use spike-like pinnules as well as toxic chemical compounds such as polyketide derivatives and oxidized quinones that also give them their colorful appearance (Kenta et al. 2015; Feng et al. 2017). According to WoRMS ${ }^{1}$

${ }^{1}$ World Register of Marine Species.
2017, although they consist of nearly 700 species worldwide, until now only a few studies examined their bioactive compounds. According to the MarinLit database (2018), only 25 marine species from 16 different genera of crinoids have so far been screened for novel MNPs (Feng et al. 2017) (Table 7.1).

\subsubsection{Asteroids (Sea Stars)}

This class of echinoderms is, with over 1500 species, widely distributed and thus plays important ecological roles. Asteroids are opportunistic feeders, and species such as the temperate Ochre sea star Pisaster ochraceus and the tropical coral-eating crown of thorn sea star Acanthaster planci are keystone species (Paine 1969). Asteroids are known to use both physical and chemical defense mechanisms. Autotomy (i.e., found in Evasterias troschelii and Pycnopodia helianthoides), spines, modified tube feet called "pedicellaria," camouflage, quick locomotion, and shedding have been reported as physical defenses (Bryan et al. 1997; Candia Carnevali and Bonasoro 2001). However, some species such as the sea star Pteraster tesselatus rely to a great extent on their mucus as chemical defense (Nance and Braithwaite 
Table 7.2 Steroidal compounds reported from echinoderms, except Holothuroids, and (if reported) their biological activities (Holothuroids see Table 7.3)

\begin{tabular}{|c|c|c|c|c|c|}
\hline Class & Family & Species & Isolated compounds & Biological activity & References \\
\hline Crinoids & Hemicrinidea & $\begin{array}{l}\text { Neogymnocrinus } \\
\text { richeri }\end{array}$ & Several steroids & n.d. & $\begin{array}{l}\text { De Riccardis et al. } \\
\text { (1991) }\end{array}$ \\
\hline \multirow[t]{28}{*}{ Asteroids } & \multirow[t]{28}{*}{ Asteriidae } & \multirow[t]{5}{*}{$\begin{array}{l}\text { Asterias } \\
\text { amurensis }\end{array}$} & $\begin{array}{l}\text { Thornasteroside A, versicosides } \\
\text { A-C, and asteronylpentaglycoside } \\
\text { sulfate, anasteroside B }\end{array}$ & n.d. & $\begin{array}{l}\text { Hwang et al. (2011, } \\
\text { 2014) }\end{array}$ \\
\hline & & & Crude saponin & $\begin{array}{l}\text { Insecticide and } \\
\text { repellant activity }\end{array}$ & Park et al. (2009) \\
\hline & & & $\begin{array}{l}\text { Asterosides A-D, glycoside B, } \\
\text { asterosaponins }\end{array}$ & n.d. & Riccio et al. (1988) \\
\hline & & & Asterosaponin-4 & Cytotoxic & Okano et al. (1985) \\
\hline & & & Asterosaponin $\mathrm{A}, \mathrm{A}_{4}$ & Antitumor & Ikegami et al. (1973) \\
\hline & & Asterias vulgaris & 13 steroidal compounds & n.d. & $\begin{array}{l}\text { Findlay and Agarwal } \\
\text { (1983) }\end{array}$ \\
\hline & & \multirow[t]{4}{*}{ Asterias forbesi } & Forbeside D & n.d. & Findlay and He (1991) \\
\hline & & & Forbesides A-B & $\begin{array}{l}\text { Anti-inflammatory, } \\
\text { Antiviral }\end{array}$ & Findlay et al. (1987) \\
\hline & & & Forbesides C-E, $\mathrm{E}_{1}-\mathrm{E}_{3}, \mathrm{~F}-\mathrm{H}, \mathrm{L}$ & n.d. & $\begin{array}{l}\text { Findlay et al. (1989), } \\
\text { Findlay and He (1991), } \\
\text { D'Auria et al. (1993), } \\
\text { and Jiang et al. (1993) }\end{array}$ \\
\hline & & & Forbeside $\mathrm{H}$ & n.d. & Findlay et al. (1992) \\
\hline & & Asterias rubens & Ruberosides A-F & n.d. & $\begin{array}{l}\text { Sandvoss et al. (2000, } \\
\text { 2003) }\end{array}$ \\
\hline & & Asterias rathbuni & Rathbuniosides $\mathrm{R}_{1}-\mathrm{R}_{2}$ & Cytotoxic & $\begin{array}{l}\text { Prokof'eva et al. } \\
(2003)\end{array}$ \\
\hline & & \multirow[t]{2}{*}{$\begin{array}{l}\text { Anasterias } \\
\text { minuta }\end{array}$} & Minutosides A, B & Antifungal & Chludil et al. (2002b) \\
\hline & & & Anasterosides A-B, versicoside A & Antifungal & Chludil et al. (2002b) \\
\hline & & $\begin{array}{l}\text { Asterias } \\
\text { rollestoni }\end{array}$ & Amurensoside, forbeside & & Zhang et al. (2013) \\
\hline & & \multirow[t]{3}{*}{$\begin{array}{l}\text { Aphelasterias } \\
\text { japonica }\end{array}$} & Aphelasteroside F & $\begin{array}{l}\text { Inhibition of cell } \\
\text { proliferation }\end{array}$ & Popov et al. (2016) \\
\hline & & & Ophidianoside F & n.d. & Ivanchina et al. (2005) \\
\hline & & & $\begin{array}{l}\text { Aphelasteroside C (1), } \\
\text { cheliferoside } \mathrm{L}_{1} \\
(2), 3-O-\text {-sulfoasterone (3), } \\
\text { forbeside } \mathrm{E}_{3}(4), \text { and } \\
\text { 3-O-sulfothornasterol A (5) } \\
\text { aphelaketotriol (6) }\end{array}$ & $\begin{array}{l}\text { Hemolytic activity } \\
\text { except compound (3) }\end{array}$ & Ivanchina et al. (2000) \\
\hline & & \multirow[t]{2}{*}{$\begin{array}{l}\text { Leptasterias } \\
\text { hylodes }\end{array}$} & Polyhydroxylated steroids & $\begin{array}{l}\text { Antibacterial, } \\
\text { hemolytic activity }\end{array}$ & Levina et al. (2010) \\
\hline & & & Hylodoside $\mathrm{A}$, novaeguinoside $\mathrm{Y}$ & Hemolytic activity & Levina et al. (2010) \\
\hline & & $\begin{array}{l}\text { Leptasterias } \\
\text { ochotensis }\end{array}$ & Leptasteriosides A-F & Anticancer & $\begin{array}{l}\text { Malyarenko et al. } \\
(2014)\end{array}$ \\
\hline & & $\begin{array}{l}\text { Diplasterias } \\
\text { brucei }\end{array}$ & Diplasteriosides A, B & Anticancer & Ivanchina et al. (2011) \\
\hline & & $\begin{array}{l}\text { Coscinasterias } \\
\text { tenuispina }\end{array}$ & $\begin{array}{l}\text { Tenuispinosides A-C, } \\
\text { coscinasteroside A-F }\end{array}$ & n.d. & Riccio et al. (1986d) \\
\hline & & \multirow[t]{2}{*}{$\begin{array}{l}\text { Distolasterias } \\
\text { nipon }\end{array}$} & $\begin{array}{l}\text { Nipoglycosides A-D, versicoside } \\
\text { A, and thornasteroside A }\end{array}$ & n.d. & Minale et al. (1995) \\
\hline & & & Distolasterosides $\mathrm{D}_{1}-\mathrm{D}_{3}$ & $\begin{array}{l}\text { Neurogenic and } \\
\text { neuroprotective effect }\end{array}$ & Palyanova et al. (2013) \\
\hline & & $\begin{array}{l}\text { Distolasterias } \\
\text { elegans }\end{array}$ & Pycnopodioside $\mathrm{C}$ & n.d. & $\begin{array}{l}\text { Andriyashchenko et al. } \\
(1996)\end{array}$ \\
\hline & & $\begin{array}{l}\text { Lethasterias } \\
\text { fusca }\end{array}$ & Lethasterioside A & Anticancer & Ivanchina et al. (2012) \\
\hline & & $\begin{array}{l}\text { Lysastrosoma } \\
\text { anthosticta }\end{array}$ & Lysaketotriol and iysaketodiol & $\begin{array}{l}\text { Immunomodulatory } \\
\text { activities }\end{array}$ & Levina et al. (2009) \\
\hline
\end{tabular}


Table 7.2 (continued)

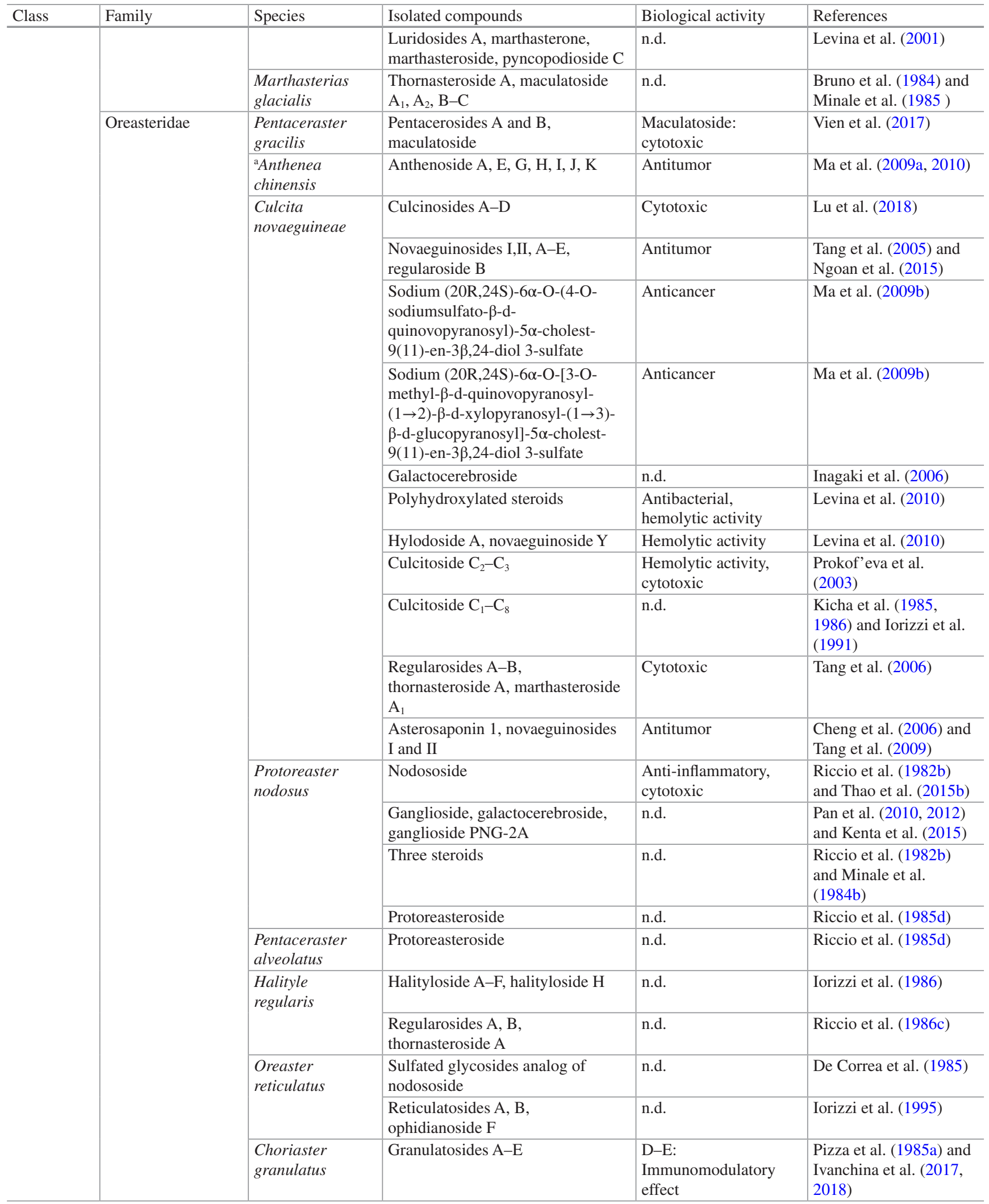


Table 7.2 (continued)

\begin{tabular}{|c|c|c|c|c|c|}
\hline Class & Family & Species & Isolated compounds & Biological activity & References \\
\hline & \multirow[t]{15}{*}{ Ophidiasteridae } & \multirow[t]{3}{*}{$\begin{array}{l}\text { Hacelia } \\
\text { attenuata }\end{array}$} & $\begin{array}{l}\text { Nodososide, attenuatosides A-I, } \\
\text { B-I, B-II, and C, } \\
\text { polyhydroxysteroids }\end{array}$ & n.d. & Minale et al. (1983) \\
\hline & & & $\begin{array}{l}\text { Attenuatosides S-I-S-III, S-D, } \\
\text { thornasteroid }\end{array}$ & n.d. & Minale et al. (1984a) \\
\hline & & & Ophidianosides B, C, F & n.d. & Riccio et al. (1985c) \\
\hline & & \multirow[t]{5}{*}{ Linckia laevigata } & $\begin{array}{l}\text { Thornasteroside } \mathrm{A} \text {, } \\
\text { marthasteroside } \mathrm{A}_{1} \text {, ophidianoside } \\
\mathrm{F} \text {, maculatoside, laevigatoside }\end{array}$ & n.d. & Riccio et al. (1985b) \\
\hline & & & Granulatoside A & Neuritogenic activity & Qi et al. (2006) \\
\hline & & & Nodososide & n.d. & Minale et al. (1984c) \\
\hline & & & Linckosides A-Q & Neuritogenic activity & $\begin{array}{l}\text { Qi et al. (2002, 2004) } \\
\text { and Han et al. (2006, } \\
\text { 2007a) }\end{array}$ \\
\hline & & & $\begin{array}{l}\text { Linckosides } \mathrm{L}_{1}-\mathrm{L}_{7} \text {, echinasteroside } \\
\text { C }\end{array}$ & $\begin{array}{l}\text { Neuritogenic activity, } \\
\text { cytotoxic }\end{array}$ & $\begin{array}{l}\text { Kicha et al. (2007a, b, } \\
\text { c) }\end{array}$ \\
\hline & & $\begin{array}{l}\text { Ophidiaster } \\
\text { ophidianus }\end{array}$ & Ophidianoside B-F & n.d. & Riccio et al. (1985c) \\
\hline & & \multirow[t]{4}{*}{$\begin{array}{l}\text { Certonardoa } \\
\text { semiregularis }\end{array}$} & Certonardoside A-J, halytoside D & Antiviral & Wang et al. (2002) \\
\hline & & & $\begin{array}{l}\text { Certonardoside K-N, culcitoside } \\
\mathrm{C}_{6}\end{array}$ & $\begin{array}{l}\text { Cytotoxic, } \\
\text { antibacterial }\end{array}$ & Wang et al. (2003) \\
\hline & & & $\begin{array}{l}\text { Certonardosterol } \mathrm{Q}_{1}-\mathrm{Q}_{7}, \mathrm{~B}_{2}-\mathrm{B}_{4}, \\
\mathrm{~A}_{2}-\mathrm{A}_{4}, \mathrm{D}_{2}-\mathrm{D}_{5}, \mathrm{H}_{3}, \mathrm{H}_{4}, \mathrm{E}_{2}, \mathrm{E}_{3}, \mathrm{P}_{1} \text {, } \\
\mathrm{O}_{1}\end{array}$ & Cytotoxic, antitumor & Wang et al. $(2004 a, b)$ \\
\hline & & & $\begin{array}{l}\text { Certonardoside } \mathrm{B}_{2}, \mathrm{~B}_{3}, \mathrm{P}_{1}, \mathrm{P}_{2}, \mathrm{O}_{1} \text {, } \\
\mathrm{J}_{2}, \mathrm{~J}_{3}, \mathrm{I}_{2}, \mathrm{I}_{3}, \mathrm{H}_{2}\end{array}$ & Cytotoxic, antitumor & $\begin{array}{l}\text { Wang et al. (2004a, } \\
\text { 2005) }\end{array}$ \\
\hline & & $\begin{array}{l}\text { Nardoa } \\
\text { gomophia }\end{array}$ & $\begin{array}{l}\text { Halityloside } \mathrm{A}, \mathrm{B}, \mathrm{D}, \mathrm{E}, \mathrm{H}, \mathrm{I}, \\
\text { marthasteroside } \mathrm{A}_{1} \text {, thornasteroide } \\
\mathrm{A} \text {, and } 2 \text { polyhydroxysteroids }\end{array}$ & n.d. & Riccio et al. (1986b) \\
\hline & & $\begin{array}{l}\text { Nardoa } \\
\text { novaecaledonia }\end{array}$ & Halityloside A, B, D & n.d. & Riccio et al. (1986b) \\
\hline & \multirow[t]{7}{*}{ Asterinidae } & \multirow[t]{4}{*}{$\begin{array}{l}\text { Patiria } \\
\text { pectinifera }\end{array}$} & Polyhydroxysteroids & Cytotoxic. & Peng et al. (2010) \\
\hline & & & Cucumarioside $\mathrm{F}_{1}, \mathrm{~F}_{2}$ & $\begin{array}{l}\text { Indicative of trophic } \\
\text { marker }\end{array}$ & Popov et al. (2014) \\
\hline & & & $\begin{array}{l}\text { Asterosaponin } \mathrm{P}_{1}, \mathrm{P}_{2}, \\
\text { polyhydroxysteroids }\end{array}$ & $\begin{array}{l}\text { Asterosaponin P1: } \\
\text { neurogenic and } \\
\text { neuroprotective effect }\end{array}$ & $\begin{array}{l}\text { Kicha et al. (1983, } \\
\text { 2000, 2004) and } \\
\text { Palyanova et al. (2013) }\end{array}$ \\
\hline & & & Pectinoside A & $\begin{array}{l}\text { Immunological } \\
\text { activity }\end{array}$ & Kawase et al. (2016) \\
\hline & & $\begin{array}{l}\text { Asterina } \\
\text { pectinifera }\end{array}$ & $\begin{array}{l}\text { Pectiniosides A-J, } \\
\text { acanthaglycciside C }\end{array}$ & Cytotoxic & $\begin{array}{l}\text { Dubois et al. (1988), } \\
\text { Honda et al. (1990), } \\
\text { Jiang and Schmidt } \\
\text { (1992), and Li et al. } \\
\text { (2013) }\end{array}$ \\
\hline & & Asterina batheri & Astebatheriosides A-D & $\begin{array}{l}\text { Astebatheriosides } \\
\text { B-D: } \\
\text { anti-inflammatory }\end{array}$ & Thao et al. (2013) \\
\hline & & Patiria miniata & Patiriosides A-G & Antitumor & $\begin{array}{l}\text { Dubois et al. (1988), } \\
\text { and D'Auria et al. } \\
\text { (1990) }\end{array}$ \\
\hline
\end{tabular}


Table 7.2 (continued)

\begin{tabular}{|c|c|c|c|c|c|}
\hline Class & Family & Species & Isolated compounds & Biological activity & References \\
\hline & \multirow[t]{5}{*}{ Asteropectinidae } & $\begin{array}{l}\text { Astropecten } \\
\text { polyacanthus }\end{array}$ & Astropectenols A, C, D & Antiparasitic & $\begin{array}{l}\text { Thao et al. (2013, } \\
\text { 2014) }\end{array}$ \\
\hline & & $\begin{array}{l}\text { Astropecten } \\
\text { monacanthus }\end{array}$ & Astrosteriosides A, D, C & $\begin{array}{l}\text { Anti-inflammatory, } \\
\text { anticancer }\end{array}$ & $\begin{array}{l}\text { Thao et al. (2013, } \\
\text { 2014) and Dai and Yu } \\
(2015)\end{array}$ \\
\hline & & $\begin{array}{l}\text { Craspidaster } \\
\text { hesperus }\end{array}$ & Asterosaponin & n.d. & Wen et al. (2004) \\
\hline & & $\begin{array}{l}\text { Psilaster } \\
\text { cassiope }\end{array}$ & Psilasteroside & Cytotoxic & De Marino et al. (2003) \\
\hline & & $\begin{array}{l}\text { Astropecten } \\
\text { latespinosus }\end{array}$ & Latespinosides A-D & Weak-cytotoxic & Higuchi et al. (1996) \\
\hline & \multirow[t]{15}{*}{ Echinasteridae } & \multirow[t]{3}{*}{$\begin{array}{l}\text { Henricia } \\
\text { leviuscula }\end{array}$} & $\begin{array}{l}\text { Laevisculoside, laevisculoside } \\
\text { A-J, } \mathrm{H}_{2} \text { sanguinosides A-B }\end{array}$ & Hemolytic activity & $\begin{array}{l}\text { Kalinovskii et al. } \\
\text { (2004), and Ivanchina } \\
\text { et al. (2006) }\end{array}$ \\
\hline & & & Laevisculoside $\mathrm{G}$ & Anticancer & Fedorov et al. (2008) \\
\hline & & & Sanguinoside C & Cytotoxic & Levina et al. (2003) \\
\hline & & \multirow[t]{2}{*}{$\begin{array}{l}\text { Henricia } \\
\text { sanguinolenta }\end{array}$} & Laevisculoside, sanguinoside A-B & n.d. & $\begin{array}{l}\text { Kalinovskii et al. } \\
\text { (2004) }\end{array}$ \\
\hline & & & Sanguinoside C & Cytotoxic & Levina et al. (2003) \\
\hline & & \multirow[t]{2}{*}{$\begin{array}{l}\text { Henricia } \\
\text { derjugini }\end{array}$} & Henricioside $\mathrm{H}_{1}-\mathrm{H}_{3}$, hexaol & n.d. & Ivanchina et al. (2004) \\
\hline & & & Henricioside $\mathrm{H}_{1}$, levisculoside $\mathrm{G}$ & Antifungal & $\begin{array}{l}\text { Kaluzhskiy et al. } \\
\text { (2017) }\end{array}$ \\
\hline & & Henricia sp. & Henriciosides $\mathrm{H}_{1}-\mathrm{H}_{3}$ & n.d. & Kicha et al. (1993) \\
\hline & & $\begin{array}{l}\text { Henricia } \\
\text { downeyae }\end{array}$ & Asterosaponins & $\begin{array}{l}\text { Antibacterial, } \\
\text { antifungal, feeding } \\
\text { deterrent }\end{array}$ & Palagiano et al. (1996) \\
\hline & & $\begin{array}{l}\text { Echinaster } \\
\text { brasiliensis }\end{array}$ & $\begin{array}{l}\text { Brasilienoside, desulfated } \\
\text { dihydro-echinasteroside } \mathrm{A} \text {, } \\
\text { echinasteroside } \mathrm{B}-\mathrm{G} \text {, } \\
\text { marthasteroside } \mathrm{A}_{1}\end{array}$ & n.d. & Iorizzi et al. (1993) \\
\hline & & \multirow[t]{4}{*}{$\begin{array}{l}\text { Echinaster } \\
\text { sepositus }\end{array}$} & $\begin{array}{l}\text { 22,23-epoxysteroidal (cyclic) } \\
\text { glycosides }\end{array}$ & n.d. & $\begin{array}{l}\text { Riccio et al. (1981), } \\
\text { and Minale et al. } \\
\text { (1997) }\end{array}$ \\
\hline & & & Amurasterol, asterosterol & n.d. & $\begin{array}{l}\text { De Simone et al. } \\
(1980)\end{array}$ \\
\hline & & & Sepositoside A & Cytotoxic & $\begin{array}{l}\text { De Simone et al. } \\
\text { (1981) }\end{array}$ \\
\hline & & & $\begin{array}{l}\text { Echinasterosides A, } B_{1}, B_{2} \text {, } \\
\text { laeviusculosides } \mathrm{C}, \mathrm{I}\end{array}$ & n.d. & $\begin{array}{l}\text { Zollo et al. (1985), } \\
\text { Levina et al. (1987), } \\
\text { and Iorizzi et al. (1993) }\end{array}$ \\
\hline & & $\begin{array}{l}\text { Echinaster } \\
\text { luzonicus }\end{array}$ & Sepositoside A, luzonicosides A, D & Cytotoxic, anticancer & $\begin{array}{l}\text { De Simone et al. } \\
\text { (1981), Riccio et al. } \\
\text { (1982a), and } \\
\text { Malyarenko et al. } \\
\text { (2017) }\end{array}$ \\
\hline & \multirow[t]{3}{*}{ Stichasteridae } & $\begin{array}{l}\text { Neosmilaster } \\
\text { georgianus }\end{array}$ & Santiagoside & n.d. & Vázquez et al. (1992) \\
\hline & & \multirow[t]{2}{*}{$\begin{array}{l}\text { Cosmasterias } \\
\text { lurida }\end{array}$} & Cosmasterosides A-D, forbeside $\mathrm{H}$ & n.d. & $\begin{array}{l}\text { Roccatagliata et al. } \\
\text { (1994) }\end{array}$ \\
\hline & & & Luridosides A-B & n.d. & Maier et al. (1993) \\
\hline & \multirow[t]{3}{*}{ Asteropseidae } & \multirow[t]{3}{*}{$\begin{array}{l}\text { Asteropsis } \\
\text { carinifera }\end{array}$} & $\begin{array}{l}\text { Asteropsiside } \mathrm{A} \text {, regularoside } \mathrm{A} \text {, } \\
\text { and thornasteroside } \mathrm{A}\end{array}$ & Antitumor & $\begin{array}{l}\text { Malyarenko et al. } \\
\text { (2012) }\end{array}$ \\
\hline & & & Cariniferosides A-F & No cytotoxicity & $\begin{array}{l}\text { Malyarenko et al. } \\
\text { (2011) }\end{array}$ \\
\hline & & & Polyhydroxysteroids & n.d. & $\begin{array}{l}\text { Malyarenko et al. } \\
\text { (2010) }\end{array}$ \\
\hline
\end{tabular}


Table 7.2 (continued)

\begin{tabular}{|c|c|c|c|c|c|}
\hline Class & Family & Species & Isolated compounds & Biological activity & References \\
\hline & \multirow[t]{2}{*}{ Archasteridae } & Archaster typicus & Five steroids & Anticancer & Yang et al. (2011) \\
\hline & & & Archasterosides A-C & Anticancer & Kicha et al. $(2010 \mathrm{a}, \mathrm{b})$ \\
\hline & \multirow[t]{3}{*}{ Luidiidae } & Luidia maculata & $\begin{array}{l}\text { Thornasteroside A, maculatosides } \\
\text { A-C, } \mathrm{A}_{2}\end{array}$ & Anticancer & Minale et al. (1985) \\
\hline & & \multirow[t]{2}{*}{ Luidia quinaria } & Thornasterol & n.d. & $\begin{array}{l}\text { Andriyashchenko et al. } \\
\text { (1996) }\end{array}$ \\
\hline & & & Luidiaquinoside, psilasteroside & Cytotoxic & De Marino et al. (2003) \\
\hline & \multirow[t]{4}{*}{ Acanthasteridae } & \multirow[t]{4}{*}{$\begin{array}{l}\text { Acanthaster } \\
\text { planci }\end{array}$} & Thornasterols A and B & Cytotoxic & $\begin{array}{l}\text { Kitagawa and } \\
\text { Kobayashi (1977, } \\
1978)\end{array}$ \\
\hline & & & $\begin{array}{l}\text { Acanthaglycoside } \mathrm{B}-\mathrm{F}, \\
\text { marthasteroside } \mathrm{A}_{1} \text {, and } \\
\text { versicoside } \mathrm{A}-\mathrm{B}\end{array}$ & n.d. & $\begin{array}{l}\text { Itakura and Komori } \\
\text { (1986) }\end{array}$ \\
\hline & & & $\begin{array}{l}\text { 5-Deoxyisonodososide, } \\
\text { isonodososide }\end{array}$ & Cytotoxic & Pizza et al. (1985b) \\
\hline & & & Nodososide & n.d. & Minale et al. (1984c) \\
\hline & \multirow[t]{3}{*}{ Goniopectinidae } & $\begin{array}{l}\text { Goniopecten } \\
\text { demonstrans }\end{array}$ & Goniopectenosides A-C & Antifouling & De Marino et al. (2000) \\
\hline & & \multirow[t]{2}{*}{$\begin{array}{l}\text { Hippasteria } \\
\text { phrygiana }\end{array}$} & Hippasteriosides A-D & $\begin{array}{l}\text { Hippasterioside D: } \\
\text { anticancer }\end{array}$ & Kicha et al. (2011) \\
\hline & & & $\begin{array}{l}\text { Phrygiasterol (1), phrygioside B } \\
\text { (2), borealoside C (3) }\end{array}$ & $(1,2)$ : Anticancer & $\begin{array}{l}\text { Levina et al. (2004, } \\
\text { 2005) }\end{array}$ \\
\hline & \multirow[t]{2}{*}{ Goniasteridae } & $\begin{array}{l}\text { Mediaster } \\
\text { murrayi }\end{array}$ & Mediasteroside $\mathrm{M}_{1}$ & Anticancer & Prokof'eva et al. 2003 \\
\hline & & $\begin{array}{l}\text { Ceramaster } \\
\text { patagonicus }\end{array}$ & Ceramasterosides $\mathrm{C}_{1}-\mathrm{C}_{3}$ & Cytotoxic & $\begin{array}{l}\text { Prokof'eva et al. } \\
\text { (2003) }\end{array}$ \\
\hline & \multirow[t]{2}{*}{ Heliasteridae } & $\begin{array}{l}\text { Heliaster } \\
\text { helianthus }\end{array}$ & Helianthoside & Cytotoxic & Vázquez et al. 1993 \\
\hline & & $\begin{array}{l}\text { Labidiaster } \\
\text { annulatus }\end{array}$ & Labiasteroside A & n.d. & de Vivar et al. (1999) \\
\hline & Solarestridae & $\begin{array}{l}{ }^{\mathrm{b}} \text { Solaster } \\
\text { borealis }\end{array}$ & $\begin{array}{l}\text { Solasteroside A, borealosides } \\
\text { A-D, amurenoside B }\end{array}$ & Cytotoxic & Iorizzi et al. (1992) \\
\hline & Zoroasteridae & $\begin{array}{l}\text { Myxoderma } \\
\text { platyacanthum }\end{array}$ & $\begin{array}{l}\text { Myxodermoside } \mathrm{A} \text { and } 9 \\
\text { polyhydroxysteroids }\end{array}$ & n.d. & Finamore et al. (1991) \\
\hline & Brisingidae & $\begin{array}{l}\text { Novodinia } \\
\text { antillensis }\end{array}$ & $\begin{array}{l}\text { steroidal saponins: Sch } 725737 \\
\text { and Sch } 725739\end{array}$ & Cytotoxic & Yang et al. (2007) \\
\hline \multirow[t]{8}{*}{ Ophiuroids } & \multirow[t]{3}{*}{ Ophiocomidae } & $\begin{array}{l}{ }^{\mathrm{c} O p h i o c o m a} \\
\text { dentata }\end{array}$ & Sulfated polyhydroxysterols & Antiviral & D’Auria et al. (1993) \\
\hline & & $\begin{array}{l}\mathrm{d} \text { Ophiarthrum } \\
\text { elegans }\end{array}$ & Sulfated polyhydroxysterols & Antiviral & $\begin{array}{l}\text { D'Auria et al. (1987, } \\
\text { 1993) }\end{array}$ \\
\hline & & $\begin{array}{l}\text { Ophiocoma } \\
\text { erinaceus }\end{array}$ & n.d. & Hemolytic activity & Amini et al. (2014) \\
\hline & Ophiopholidae & $\begin{array}{l}\text { Ophiopholis } \\
\text { aculeata }\end{array}$ & Sulfated polyhydroxysterols & $\begin{array}{l}\text { Cytotoxic and } \\
\text { hemolytic activity }\end{array}$ & Aminin et al. (1995) \\
\hline & Ophiomyxidae & $\begin{array}{l}\text { Ophiarachna } \\
\text { incrassata }\end{array}$ & Sulfated polyhydroxysterols & Antiviral & $\begin{array}{l}\text { D'Auria et al. (1987, } \\
\text { 1993) }\end{array}$ \\
\hline & Hemieuryalidae & $\begin{array}{l}\text { Ophioplocus } \\
\text { januarii }\end{array}$ & Sulfated steroids & Antiviral & $\begin{array}{l}\text { Roccatagliata et al. } \\
\text { (1996) }\end{array}$ \\
\hline & Gorgonocephalidea & $\begin{array}{l}\text { Astrotoma } \\
\text { agassizii }\end{array}$ & Polyhydroxysterols & Antiviral & Comin et al. (1999) \\
\hline & Ophiodermatidae & $\begin{array}{l}\text { Ophioderma } \\
\text { longicauda }\end{array}$ & Longicaudosides A-B & n.d. & $\begin{array}{l}\text { Riccio et al. (1985a, } \\
\text { 1986a) }\end{array}$ \\
\hline \multirow[t]{2}{*}{ Echinoids } & Diadematidae & $\begin{array}{l}\text { Diadema } \\
\text { savignyi }\end{array}$ & Steroidal compounds & Anticancer & Thao et al. (2015a) \\
\hline & Toxopneustidae & $\begin{array}{l}\text { Tripneustes } \\
\text { gratilla }\end{array}$ & Epidioxysterol & Cytotoxic & Liu et al. (2011) \\
\hline
\end{tabular}

"The accepted name changed from "Anthenea chinesis" to "Anthenea pentagonula"

"The accepted name changed from "Solaster borealis" to "Crossaster borealis"

"The accepted name changed from "Ophiocoma dentata" to "Breviturma dentata"

'The accepted name changed from "Ophiarthrum elegans" to "Ophiomastix elegans" 
1979). Based on the hypothesis that saponins and saponinlike compounds produce various sugars upon hydrolysis (Fieser and Fieser 1956), Ward (1960) proposed that mucouslike compounds secreted from Pteraster tessellates have a saponin or saponin-like nature. Starfishes produce a wide range of MNPs (Table 7.2), which are largely described as lipid-like or lipid soluble molecules. Asteroids produce various steroidal derivatives, fatty acids, ceramides, and few alkaloids to either defend themselves or communicate (Table 7.1). Some of the latter compounds have been reported to possess pharmacological activities (Maier, 2008). After sea cucumbers, this group of echinoderms has also been reported to produce a large number of saponins, which have been isolated from different organs (i.e., stomach, arm, gonads, and digestive system) and possess various roles in digestion (Garneau et al. 1989; Demeyer et al. 2014), reproduction (Mackie et al. 1977) and the defense against potential predators (Harvey et al. 1987). Assessing the isolated steroidal glycosides from 1973 to 2016 revealed that most of the MNP studies on sea stars had focused on the families
Asteroidea (26\%), Echinasteridae (17\%), Oreasteridae (16\%), and Ophidiasteridae (13\%; Table 7.2 and references therein).

The glycoside compounds of starfish are classified into three main groups of steroidal glycosides: asterosaponin, polyhydroxylated glycosides, and macrocyclic glycosides (Kicha et al. 2001; Maier 2008; Demeyer et al. 2014). Although steroidal glycosides are the characteristics of asteroids, triterpene glycosides have also been isolated from starfishes such as Asterias rollestoni (Zhan et al. 2006) and Patiria pectinifera (Popov et al. 2014). The isolated saponins from A. rollestoni (rollentosides A-B) have a similar aglycone and carbohydrate moiety than those observed in some sea cucumber species (Popov et al. 2014). Given the similar structures of rollentoside B (Zhan et al. 2006) and cucumarioside $A_{15}$ that have been extracted from the sea cucumber Eupentacta fraudatrix (Silchenko et al. 2012a), it has been argued that the starfish fed on the sea cucumber (Popov et al. 2014; Fig. 7.3). Furthermore, it seems that A. rollestoni is

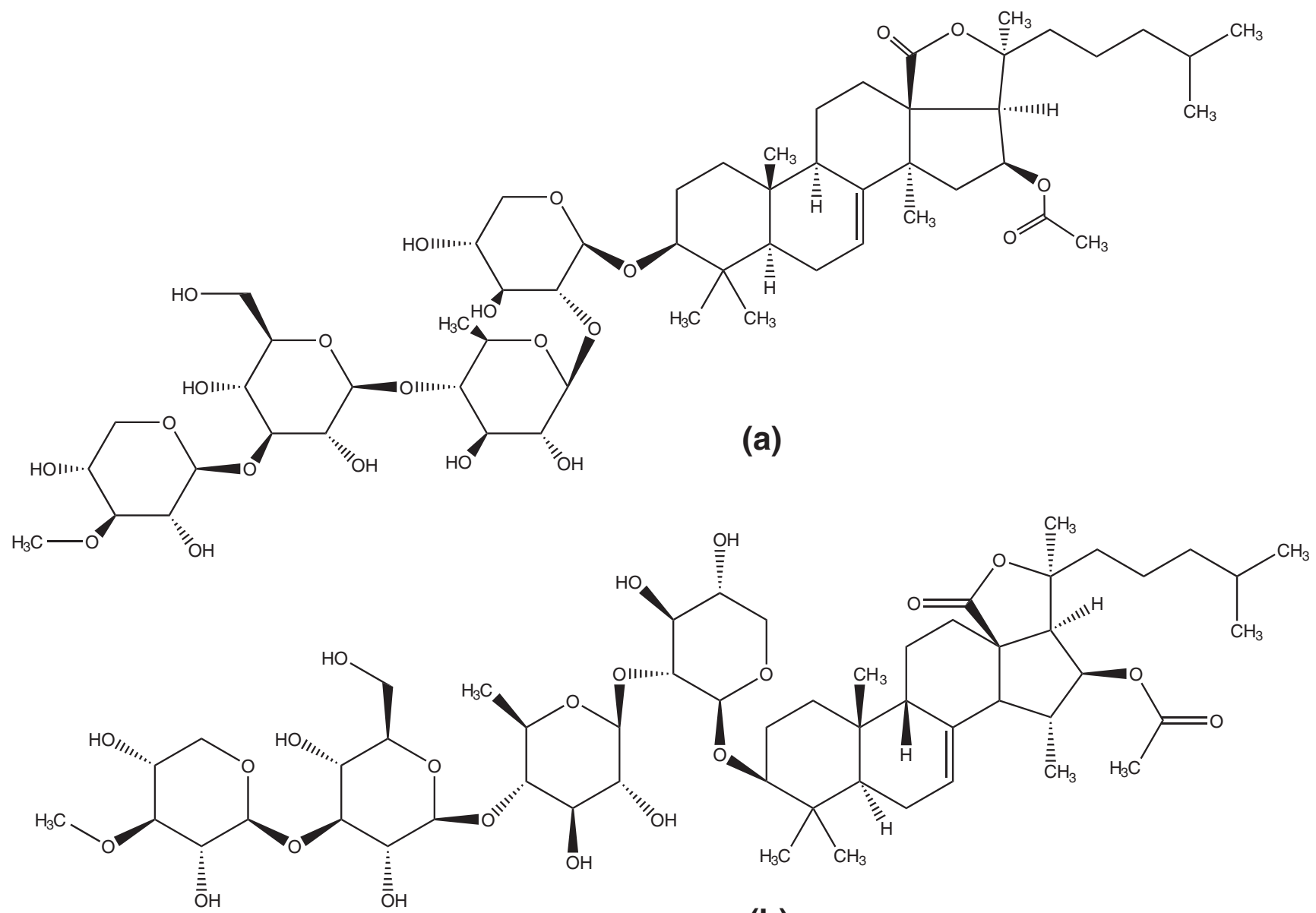

(b)

Fig. 7.3 (a) Rollentoside $\mathrm{B}$ isolated from Asterias rollestoni and (b) Cucumarioside $\mathrm{A}_{15}$ isolated from Eupentacta fraudatrix with similar chemical formula of $\mathrm{C}_{55} \mathrm{H}_{88} \mathrm{O}_{22}$ (produced with ChemDraw, version 16.0.1.4 (77)) 
able to digest and also to accumulate the toxic triterpene glycosides that were originally derived from sea cucumbers.

\subsubsection{Ophiuroids (Brittle Stars)}

With over 2000 species, brittle stars are the largest group of echinoderms (Hickman et al. 2001). These organisms are widely distributed, and their feeding behavior can be suspension feeding, deposit feeding, and/or predation (Stöhr et al. 2012). Although brittle stars have numerous physical defense mechanisms such as fast locomotion, a quick removal of their extremities, and the ability to hide under rocks and crevices, some species still rely on chemical defenses. However, based on the MarineLit database, to this day only a few studies focused on ophiuroids. Nuzzo et al. (2017) mentioned that several classes of secondary metabolites such as carotenoids, gangliosides, brominated indoles, phenylpropanoids, several groups of terpenes, and steroids have been isolated from brittle stars (Table 7.1). The presence of sulfated steroids in starfish (see Sect. 7.3) and brittle stars is an indicator of the phylogenetically close relation between these two classes of echinoderms (Levina et al. 1996, 2007).

\subsubsection{Echinoids (Sea Urchins)}

Sea urchins, the living representative of echinoids, are freemoving echinoderms (Clemente et al. 2013). They typically have physical defense mechanisms such as fused skeleton plates, spines, and pedicellaria for pinching or capturing prey (Jangoux 1984). Some families such as Diadematidae, Echinothuriidae, and Toxopneustidae contain venoms (Thiel and Watling 2015). The main MNPs of sea urchins are proteins, polysaccharides, and pigments, which are located in the spines, testes, gonads, and/or pedicellaria (Shang et al 2014; Jiao et al. 2015). Studies on their MNPs have mainly focused on proteins derived from naphthoquinone pigments that showed antibacterial, antioxidant, and anti-inflammatory activities. Few studies focused on steroidal components of sea urchins (Table 7.2), with the exception of Tripneustes gratilla (Liu et al., 2011) and Diadema savignyi (Thao et al. 2015a), from which several steroidal constituents had been described.

\subsubsection{Holothuroids (Sea Cucumbers)}

Sea cucumbers have been recognized as an interesting source of MNPs, since they are already used as traditional food and medicine source in Asian countries (i.e., healing wounds, eczema, arthritis, impotence; Ridzwan 2007; Althunibat et al. 2013). The enriched nutrition profile of sea cucumbers and their high protein, low sugar, and cholesterol-free content make holothurians a valuable food source, especially for people who suffer from hyperlipidemia (Wen et al. 2010; Bordbar et al. 2011). To date, antibacterial (Ghanbari et al. 2012; Soliman et al. 2016), antifungal (Ghannoum and Rice 1999; Soliman et al. 2016), antiviral (Mayer and Hamann 2002), antitumor and anticancer (Anisimov et al. 1973; Wu et al. 2007a; Janakiram et al. 2015; Fedorov et al. 2016), anti-schistosomal (Mona et al. 2012), and anti-inflammatory (Song et al. 2016) activities are the reported bioactive effects that were obtained from various classes of sea cucumber-derived secondary metabolites. Although a wide range of chemical classes from sea cucumbers such as peptides (Zhao et al. 2009; Song et al. 2016), polysaccharides (Liu et al. 2012; Marques et al. 2016), glycosphingolipids (Sugawara et al. 2006), polyunsaturated fatty acids (Yang et al. 2003; Hu et al. 2014b), and ceramides and gangliosides (Ikeda et al. 2009) were studied (Table 7.2), only a few products reached preclinical trials (Mayer et al. 2010).

\subsection{Saponins in Echinoderms}

The major group of bioactive compounds that are responsible for the biological activities of echinoderms are glycosides (Bhakuni and Rawat 2005; Dong et al. 2011). Saponins are common compounds that have been isolated from various terrestrial plants, but within the animal kingdom, they are reported only in few marine organism groups such as sponges (Kubanek et al. 2000), sea cucumbers (Yamanouchi 1955), and starfishes (Kitagawa and Kobayashi 1977). Echinoderms harbor in comparison to other marine invertebrates by far the most of the 350 reported saponin compounds.

Saponins are complex amphipathic glycosides composed of a steroid (largely found in sea stars) or triterpenoid aglycone (most commonly found in sea cucumbers) and a carbohydrate moiety (Minale et al. 1995). Saponins consist of hydrophilic (glycone) and hydrophobic (aglycone) components. The sugar moiety of saponins is mostly composed of glucose (Glc), xylose (Xyl), galactose (Gal), glucuronic acid (Glu), rhamnose (Rha), and/or methylpentose and is connected to the hydrophobic compartment (sapogenin) via glycosidic bonds. The nature of the side chains and the positions of various carbohydrate residues, or monosaccharide compositions, affect the membranotropic activities and functional properties of this chemical group.

Saponins show a broad range of bioactivities and ecological functions ranging from cytotoxic, hemolytic, antibacterial, antiviral, antifouling, antifungal, and anti-inflammatory activities, immunomodulatory effects, ichthyotoxicity, and deterrent/attractant properties for predators/symbionts (see Tables 7.2 and 7.3 for more details). Furthermore, the inter- 


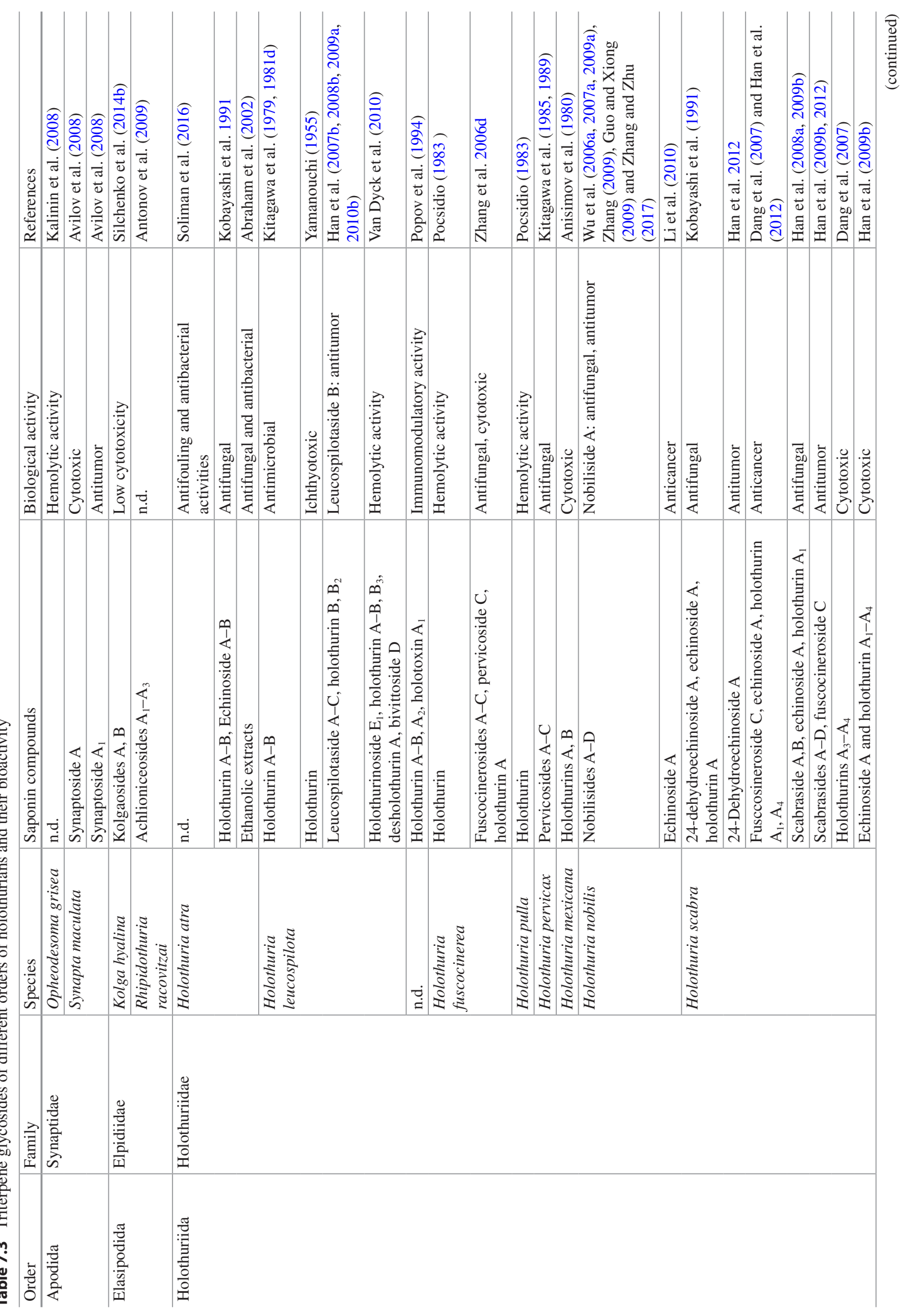




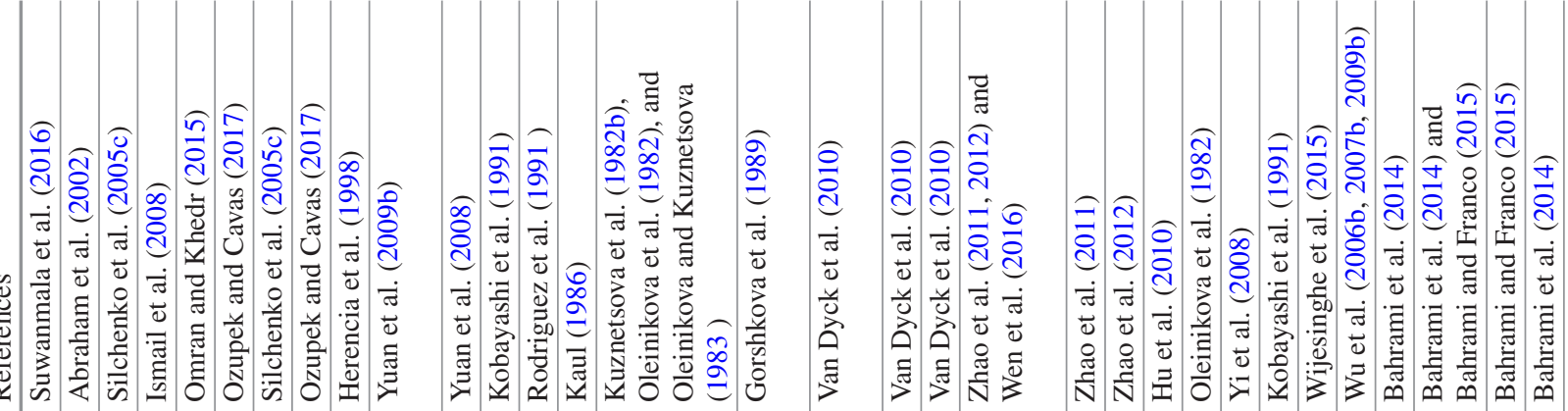

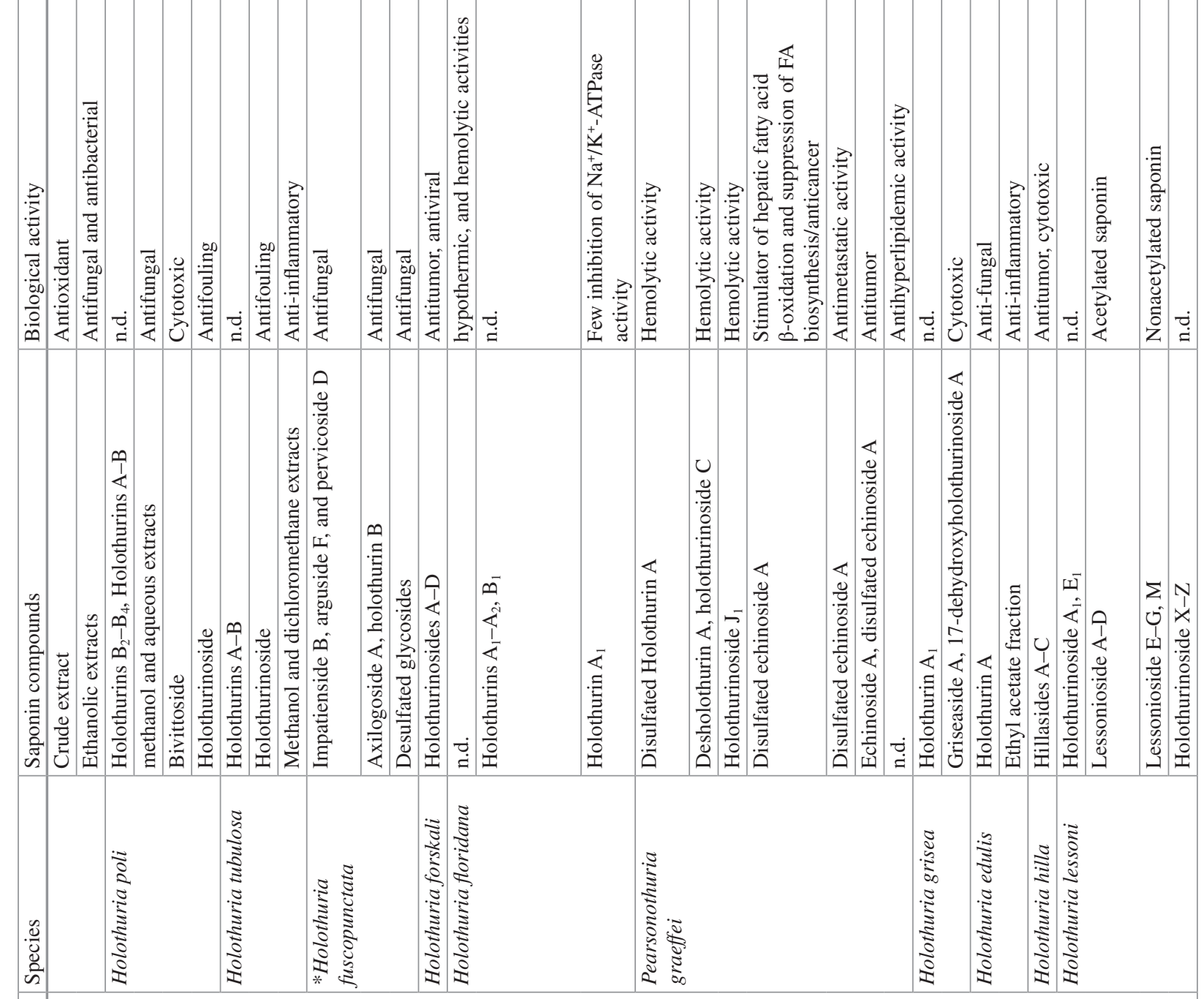

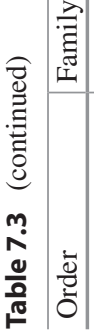




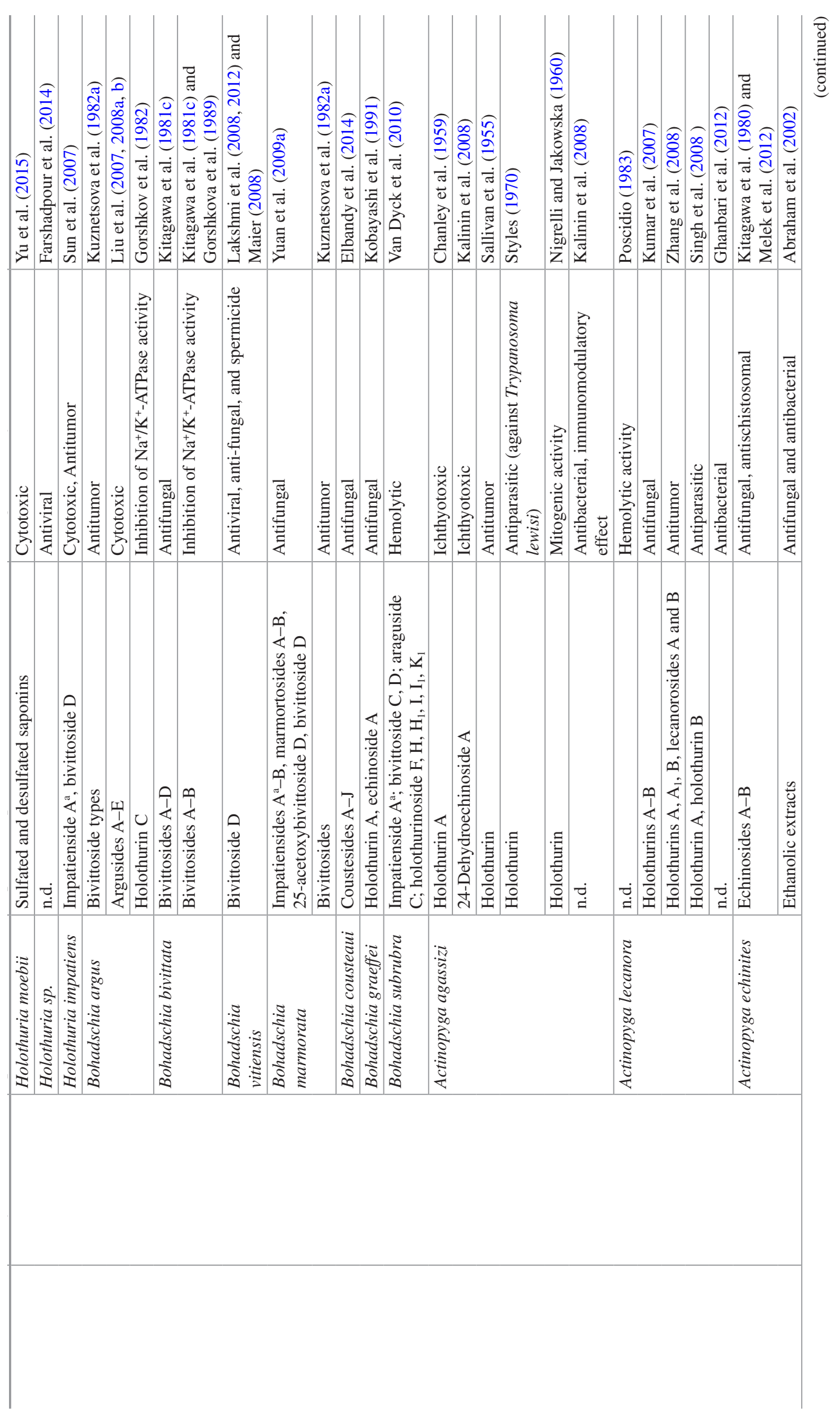



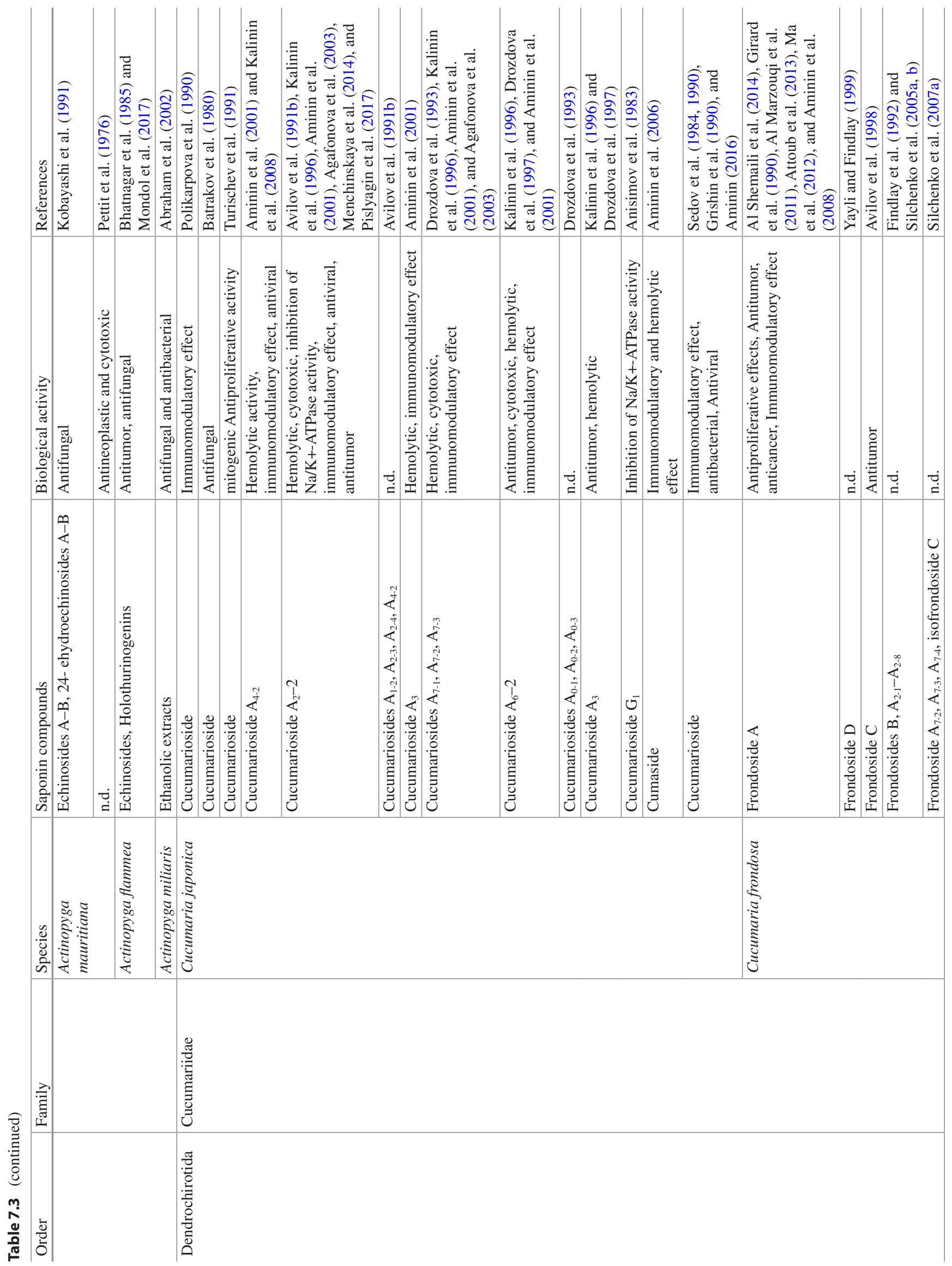


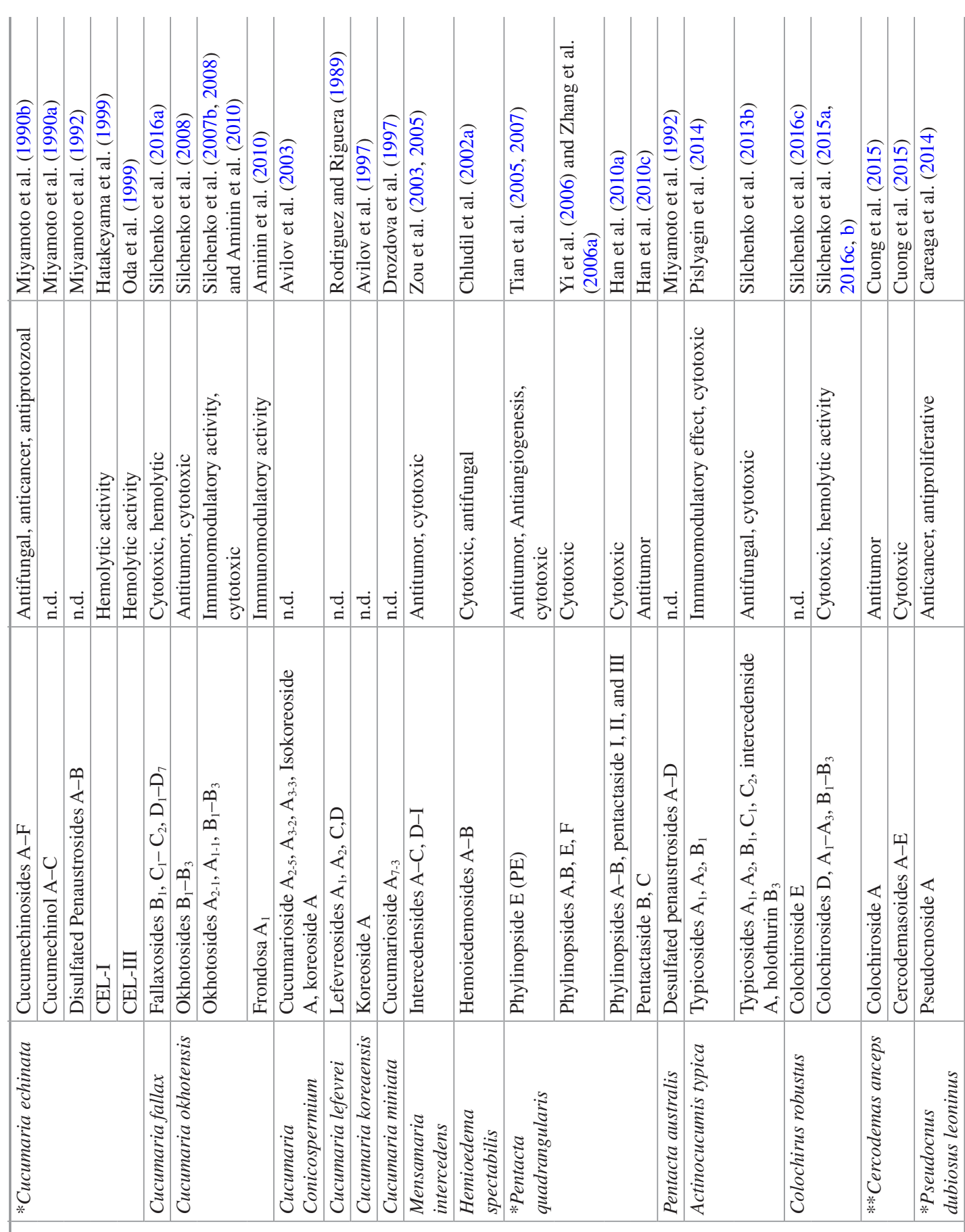




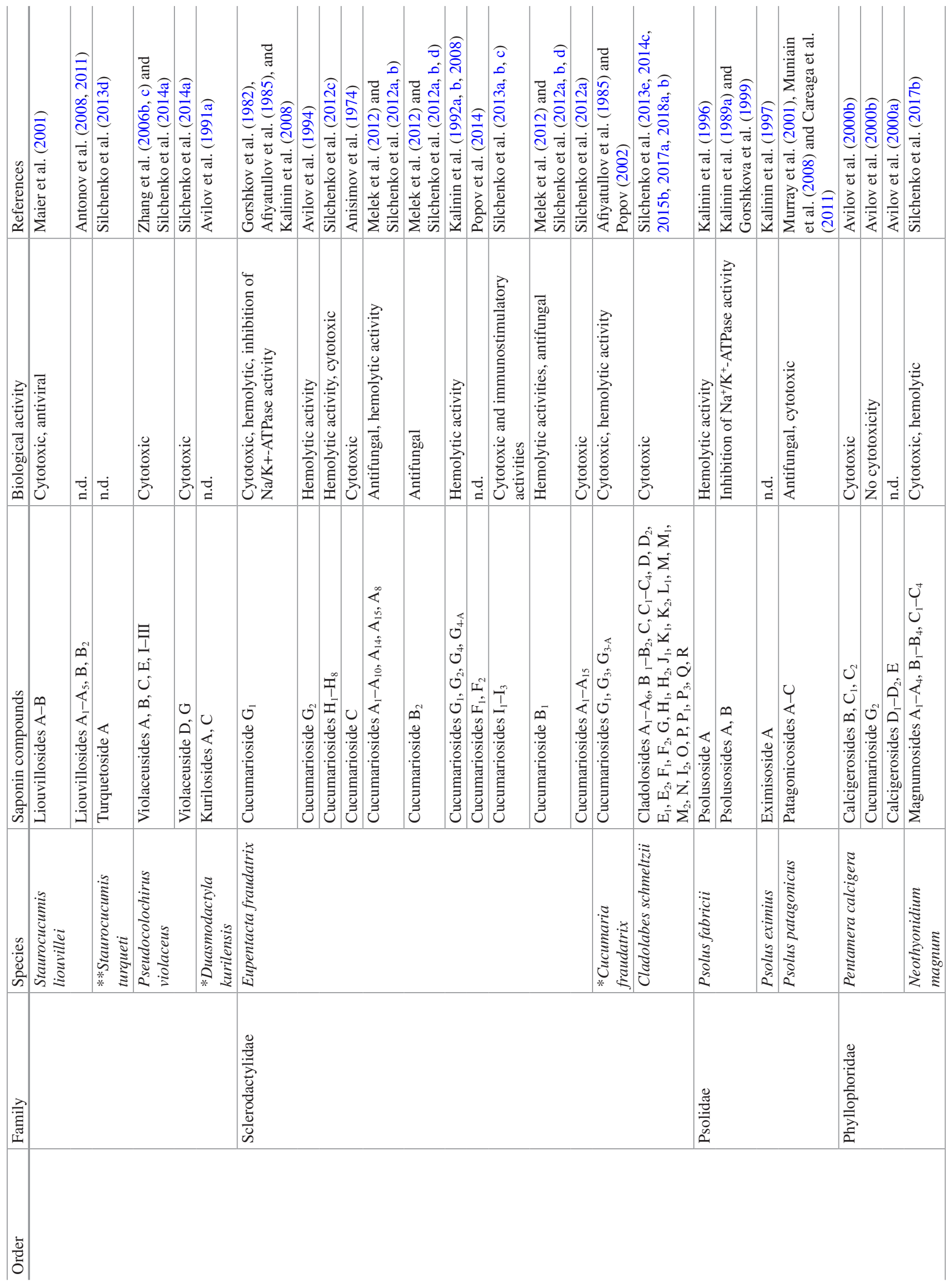




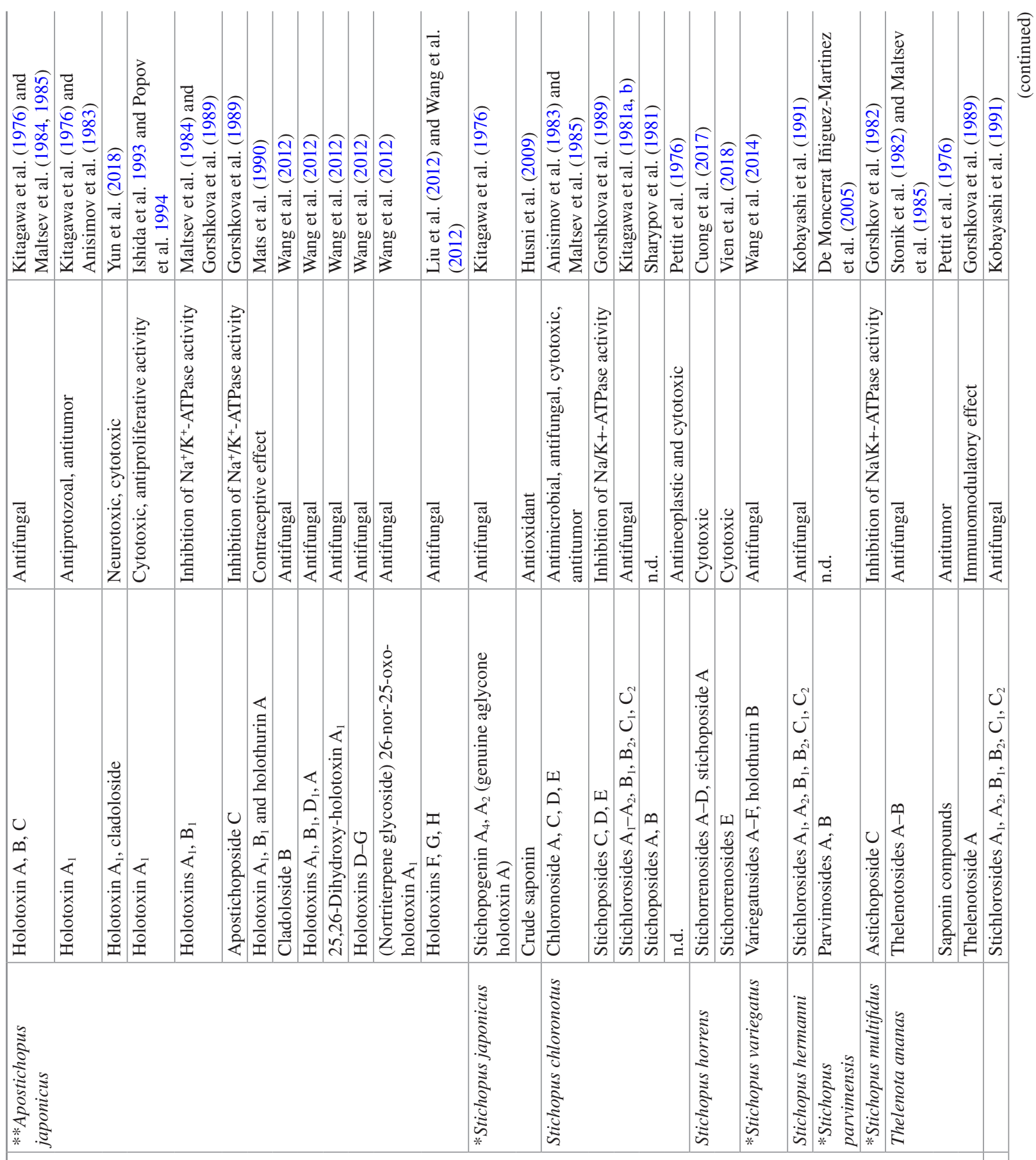

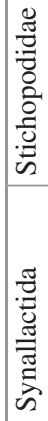




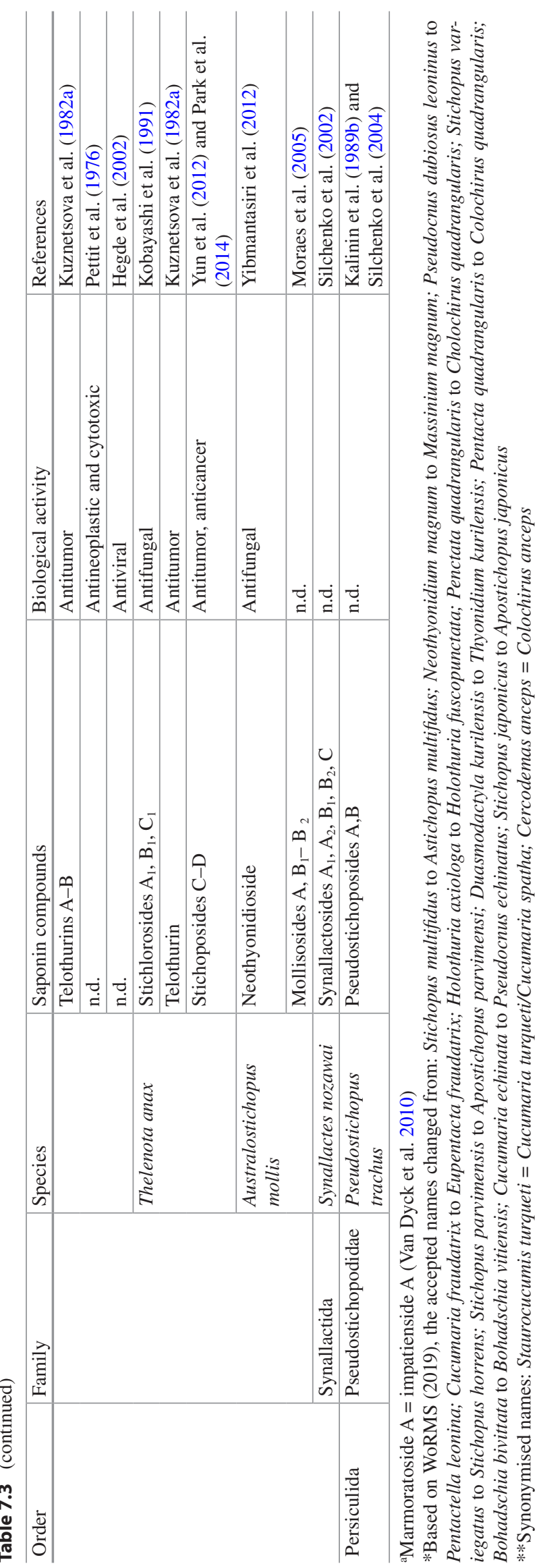




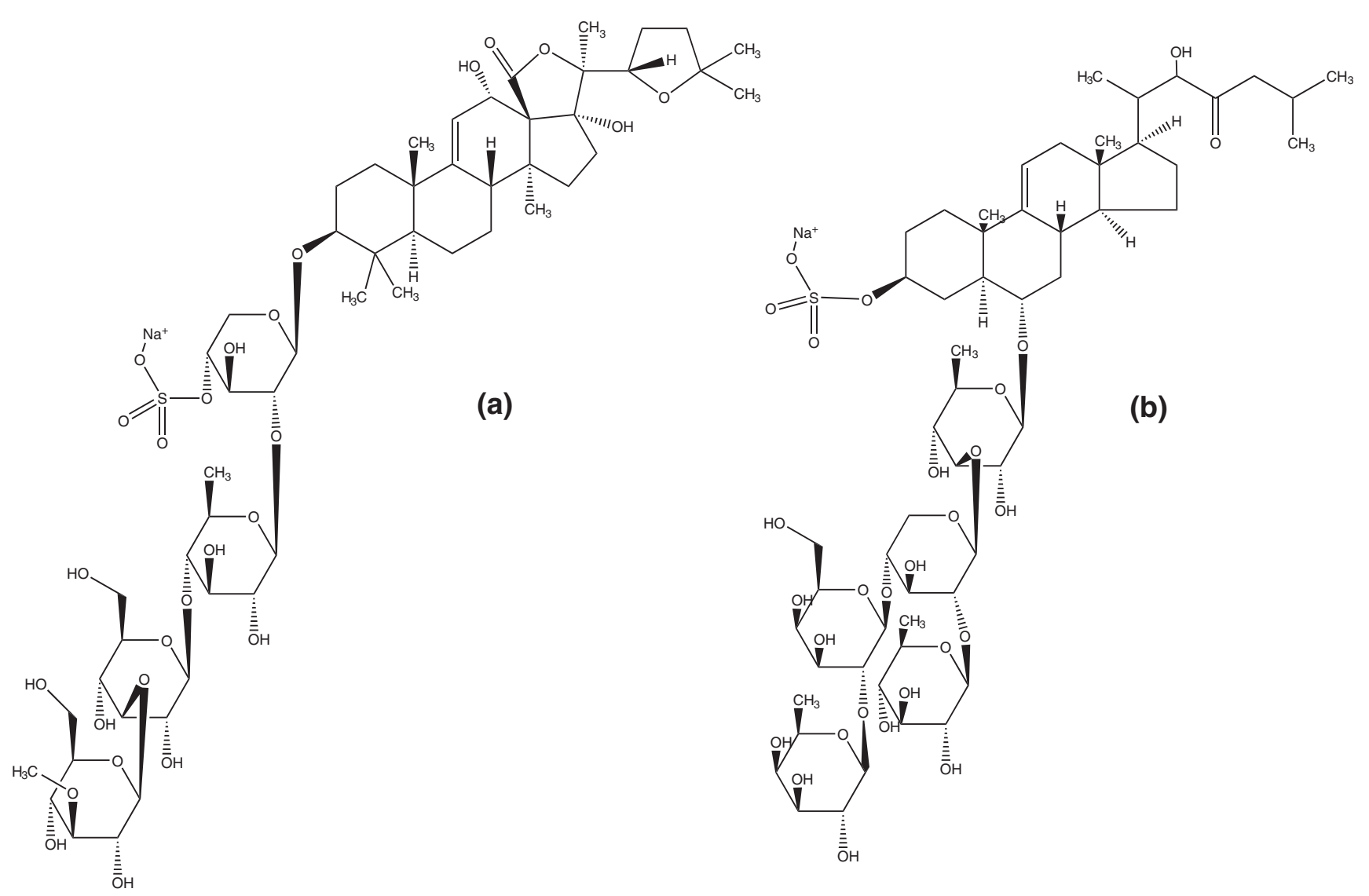

Fig. 7.4 Examples of (a) a triterpene glycoside structure: Holothurin A isolated from the sea cucumber Holothuria leucospilota (Kitagawa

actions between aglycone components (i.e., sapogenin) and sterols of the cell membranes can result in a saponification process that may lead to cell lysis (Bahrami et al. 2016).

The sulfate group seems to be one of the most essential groups in most saponins derived from ophiuroids, asteroids (Table 7.2), and holothuroids (Table 7.3). However, there is a basic difference in the position of this functional group between echinoderms (Fig. 7.4). For both sea stars and brittle stars, the sulfate group is located in the hydrophobic part (aglycone) of the molecule, whereas in holothurians the sulfate group is placed within the hydrophilic moiety (glycone) (Kornprobst et al. 1998). The structural differences of asterosaponin and triterpene glycosides showed that not only the presence but also the position of the sulfate groups may be important, resulting in potentially different biological activities of saponins (Maier 2008; Malyarenko et al. 2015).

As the sea cucumbers contain the highest variety of saponin species, we will next (see Sect. 7.3.1) focus on the distribution and function of triterpene glycosides that have been reported exclusively from holothurians. et al. 1981d) and (b) a steroidal glycoside structure: Thornasteroside A isolated from the sea star Acanthaster planci (Kitagawa and Kobayashi 1978) (produced with ChemDraw, version 16.0.1.4 (77))

\subsubsection{Structural Diversity of Saponins in Holothuroids}

The first report of polar and low volatile triterpene glycosides within the animal kingdom was in 1952 and originated from a sea cucumber extract (Nigrelli and Zahl 1952).The initial studies on the bioactive properties of compounds derived from sea cucumbers explained the ichthyotoxic activities of saponins, which were extracted from the body wall and the CTs of Holothuria leucospilota and Actinopyga agassizi (Nigrelli and Jakowska 1960; Yamanouchi, 1955). Most of the subsequently identified saponins were mainly isolated from three families of sea cucumbers: Holothuriidae, Stichopodiidae, and Cucumariidae (see Table 7.3).

The chemical structure of saponins in holothurians can be very complex in terms of the presence/absence and position of different functional groups (e.g., hydroxyl groups), which may differentiate them from other echinoderms as well as from each other marine invertebrates (Bahrami et al. 2014). The generic name of holothurian-derived saponins is Holothurin, which are nearly all $3 \beta$-glycosylated saponins 
(Kornprobst et al. 1998). In most sea cucumbers, triterpene glycosides contain the aglycone lanosterol with an 18(20)-lactone (e.g., holostane 3 $\beta$-ol; Kalinin 2000; Caulier et al. 2011) and an oligosaccharide chain that consists of D-Xyl, D-Quinov, D-Glc, D-3-O-methyl-Glc, and D-3-Omethyl-Xyl (Caulier et al. 2011; Bahrami et al. 2016).

Triterpene glycosides exhibit different bioactivities, which might aid the likelihood of survival for its producing organisms. This is also highlighted by their broad bioactivities as well as their broad ecological functions (e.g., antipredatory defense). Although the structure of each unit affects the bioactivity of the compound, linear oligosaccharide structures (i.e., tetraosides) have shown to be the optimum quantity of monosaccharide units in the glycoside (Minale et al. 1995; Kalinin et al. 2008). Furthermore, allelopathic properties of saponins, as well as the presence of various functional groups like amides, hydroxyl groups, acetyl groups, and sulfate groups in different species of sea cucumber, can inhibit larval attachment of macroorganisms and also affect the growth of different strains of gram-positive and gram-negative bacteria (Soliman et al. 2016). By changing the hydrophobic-hydrophilic balance of bacterial cells, extracted saponins may affect permeability and stability of the bacterial cell wall, which in turn can ultimately lead to cellular death (Lawrence et al., 1957; Soliman et al. 2016). Additionally, due to their hydrophilic properties, saponins regulate oocyte maturation and can thus affect the reproduction cycle of organism by synchronizing the maturation process (Kalinin et al. 2008).

The vast chemical diversity of saponin in sea cucumbers makes them effective models for studying their biochemical evolution and applying these compounds as potential holothurian chemotaxonomic markers (Kalinin et al. 1996, 2008; Kalinin 2000). Depending on the taxonomic group of sea cucumbers, the number, composition, and location of monosaccharide units, and position of functional groups in the holostane skeleton (i.e., hydroxyl, acetylate, sulfate, double bonds, etc.) may affect the bioactivity of the compounds (Stonik 1986; Kalinin 2000). For example, the presence of trisulfated glycosides in members of the family Cucumariidae is unique for this taxonomic group (Bahrami et al. 2016). Recent chemotaxonomic analysis supported the evolution of saponins in both glycone and aglycone moieties.

The general trend of glycone evolution in Holothuroidea is from non-sulfated to sulfated compounds. Bondoc et al. (2013) studied saponins from three species of Holothuroidea by using MALDI $^{2}-$ FTICR $^{3} \mathrm{MS}^{4}$ and nano-HPLC ${ }^{5}$-chip

\footnotetext{
${ }^{2}$ Matrix-assisted laser desorption/ionization.

${ }^{3}$ Fourier transformation cyclotron resonance.

${ }^{4}$ Mass spectrometry.

${ }^{5}$ Nano-high-performance liquid chromatography.
}

Q-TOF 6 -MS, and by applying maximum likelihood analysis, molecular biology, and evolutionary software packages, they created mass chemical and genetic fingerprints of saponins. They concluded that evolution of saponins leads to glycone parts with higher membranolytic activities and hydrophilicity with lower metabolic cost (Kalinin and Stonik 1996; Bondoc et al. 2013; Kalinin et al. 2015). Therefore, the glycone evolution of Holothuroidea was likely in the following order (Kalinin et al. 2016):

1. Transition from non-sulfated to sulfated hexaoside or pentaosides

2. Changing from hexaoside and pentaosides to linear tetraosides and biosides:

(a) Carbohydrate contains sulfate group at C-4 of first xylose unit.

(b) Shifting sugars with C-6 Glc and 3-O-methyl-Glc to sulfated at C-4 of first xylose

Kalinin et al. (2015) mentioned that sulfated tetraosides are a common characteristic of Holothuria and Actinopyga; however, sea cucumbers of the genus Bohadschia contain both non-sulfated and sulfated carbohydrate units (i.e., hexaosides and tetraosides). Bivittoside D extracted from Bohadschia vitiensis is a hexaoside non-sulfated glycoside that evolved to a sulfated tetraoside (Holothurin $\mathrm{A}_{2}$ ), which has been also found in Holothuria scabra (Dang et al. 2007) and Pearsonothuria graeffei (Zhao et al. 2011). Further structural modification leads to compounds with two monosaccharides (i.e., biosides such as echinoside B) from Holothuria leucospilota (Han et al. 2009a) and Actinopyga echinites (Kitagawa et al. 1985). The general direction of aglycone evolution is more complicated and depends on the presence or absence of lactone, keto, hydroxyl groups, as well as position of double bonds (Kalinin et al. 2015):

1. Presence/absence of lactone: It shifts from lanostane derivatives without lactone to lanostane with an 18(16)-lactone and holostane with an 18(20)-lactone.

2. Shifting the position of double bonds and the keto group. In general, transition of aglycones occurs from low oxidation to higher oxidized compounds.

(a) Transition of aglycone compounds having a 7(8) double bond, and a carbonyl group at C-16, to compounds oxidized at $\mathrm{C}-22$ or $\mathrm{C}-23$ without the oxygen at $\mathrm{C}-16$

(b) Transition of aglycone molecule from 9(11) double bond and C-16 keto group to compounds having oxygen at C-16, and then to compounds without oxygen, but containing a $12 \alpha$-hydroxyl group

${ }^{6}$ Quadrupole time-of-flight. 


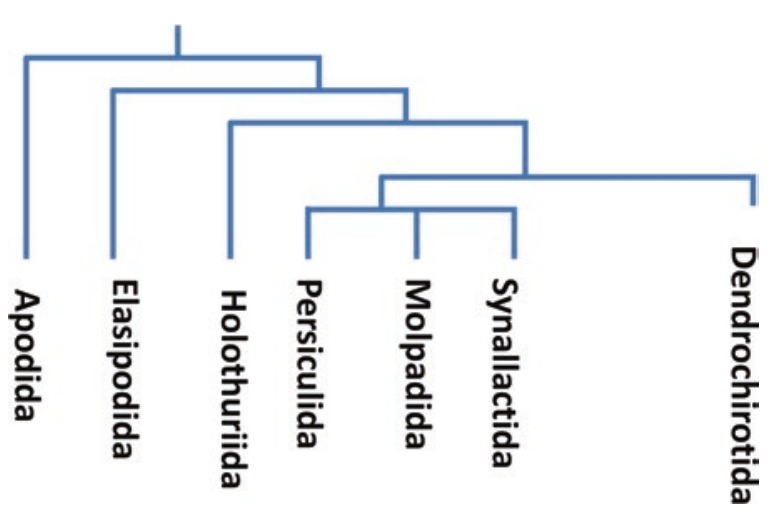

Fig. 7.5 Phylogeny of Holothuroids. Produced based on Miller et al. (2017). Holothuriida is the new accepted name for the order of Aspidochirotida

Overall, based on morphological, molecular, and paleontological analysis, there has been a clear evolutionary distance between Apodida and other species of the orders Dendrochirotida and Holothuriida (Fig. 7.5; Avilov et al. 2008). Several studies reported that the presence of the 3-O-methyl group in the terminal monosaccharide units of holothurians (Psolus fabricii, Cucumaria japonica, Hemoidema spectabilis, etc.) increased the membranolytic activities of the compound. Kalinin et al. (2008) described that during evolution of the terminal monosaccharide unit from glucoronic acid (GlcA) to Glc, the 3-O-methyl group was conserved due to the protective properties against predatory fish.

A unique group of sea cucumbers are the Synallactida. They are mostly epibenthic and their remarkable defense behavior is shedding (Kropp 1982). Their typical chemical defenses are holotoxins, stichoposides, and stichlorosides (Table 7.3). The common characteristics of stichoposides and holotoxins are the presence of a double bond at C-25 (C-26), while the presence of $\alpha$-acetoxy group at C-23 and a 3-O-methyl-D-Glc in their polysaccharide chain are another feature of stichoposides. The presence of a ketogroup at $\mathrm{C}-16$ is observed for most holotoxins. Interestingly, there is a sulfate group present in stichoposides (Mondol et al. 2017). Thus, the presence of a particular aglycone or glycone glycoside can be a taxonomic marker for certain genera such as the genera Bohadschia, Pearsonothuria, and Actinopyga (Kalinin et al. 2016). The presence, expellability, and stickiness of CTs of Holothuriidae (i.e., Bohadschia argus, Holothuria forskali) affect the chemical diversity of triterpene glycosides of the sea cucumbers (HoneyEscandón et al. 2015). Among Holothuriidae, the genus Bohadschia is considered a more primitive group since it contains well-developed CTs with expellability and stickiness and possesses non-sulfated and less-oxidized glycosides in both the CT and body wall (Kalinin et al. 1996, 2008; Honey-Escandón et al. 2015). In contrast, more sul- fated and oxidized glycosides have been reported within species without CTs or with dysfunctional CTs such as Holothuria hilla and Actinopyga echinites (HoneyEscandón et al., 2015). However, members of Dendrochirotida and Apodida also showed different patterns. Species of the order Apodida such as Synapta maculata are considered the most primitive group of Holothurians. They contain 3-O-methyl Glc-A in a carbohydrate chain and an 8(9) double bond in the aglycone moiety, which affects their membranolytic activity and hydrophilicity of the glycosides (Avilov et al. 2008).

\subsection{Discussion and Conclusions}

Predation, the biological interaction where a predator eats its prey, is a main driving force for community structure and ecosystem organization (Duffy and Hay 2001). It has been suggested that before the development of physical defenses, echinoderms used initially maternally derived chemical defenses from early larval stages to protect themselves against predators (Iyengar and Harvell 2001). Therefore, secondary metabolites play an important role in chemical defense of marine sessile and slow moving organisms and thus may affect and shape the community structure and increase the level of biodiversity of the ecosystem (Paul et al. 2007). Unfortunately, there is still a lack of information with regard to the ecological function of many MNPs, especially from echinoderms, while various pharmacological activities (e.g., antiviral, antitumor) have been widely reported. This represents a research opportunity for chemical ecologists who want to investigate how small modifications in molecules can affect ecological functions and community structure.

As summarized in Table 7.2, echinoderms have proven to be a rich source of bioactive compounds with most reported compounds in Asteroids and Holothuroids reported as saponins. Although various steroidal compounds of starfishes have been reported, only a few studies have investigated the biological activities of these compounds. Within ophiuroids, steroidal compounds, terpenes, and carotenoids have been isolated, and their mode of action has been summarized as antiviral and antitumor activities (Table 7.2).

The class Holothuria is a particularly rich source of MNPs with a multitude of reported activities. In the past decades, sea cucumbers have been increasingly harvested and consumed due to their nutritional values (high protein, low sugar, and no cholesterol (Liu et al. 2007, 2002; Wen et al. 2010) and their use in traditional medicine. Although a wide spectrum of bioactivities such as cytotoxic, hemolytic, antifungal, and immunomodulatory properties have been described for different sea cucumbers, in the extraction and compound purification process, often compounds with different chemical structures were combined, and thus the bio- 
logical function of the individual compounds remain largely unknown. Therefore, their pharmaceutical potential has not yet been fully explored, which make them still promising candidates for the discovery of future MNPs with novel pharmaceutical applications. Furthermore, past studies focused largely on shallow-water holothurians, whereas deep-water specimens encounter particular harsh physicochemical conditions. Such conditions include strong hydrostatic pressure, low temperature, and possibly oxygen shortage, which could affect formation, structure, gene regulation, and biosynthesis of secondary metabolites, thus making deep-water specimens a potential interesting target for future MNP screening campaigns.

Saponins are highly diverse, common, and abundant MNPs in echinoderms. Among this group of the secondary metabolites, holothurins, holotoxins, cucumariosides, and echinosids are the most abundant compounds in various genera of sea cucumbers (Table 7.3). Most of the reported triterpene glycosides in sea cucumbers showed cytotoxicity as well as antifouling, antifungal, and antibacterial effects of saponins (Miyamoto et al. 1990b; Aminin et al. 2015; Soliman et al. 2016), providing sea cucumbers with an effective chemical defense mechanism against microbial attacks, fouling organisms, and potentially predators.

The principal mechanisms for the bioactivities of triterpene glycosides are most likely changing membranolytic effects and increased hydrophilicity of the compounds, which may not only affect their bioactivities but also make them potential trophic and taxonomic markers. Depending on the marine habitat and the defensive responses of holothurians, each group contains their own special mixture of saponins, which are often unique chemical signatures and thus can be used in chemotaxonomy to differentiate most holothurians at the family level. Furthermore, by studying structure-activity relationships (SAR), taxonomists may be able to predict physiological differences and their ecological role within the organisms.

Defense responses of holothurians vary at order or family levels, which is to some extend reflected in the stereochemistry of the saponins. The general evolution of aglycone is based on the presence/absence or position of lactone, keto, hydroxyl groups, and double bonds, which leads from low oxidized to more oxidized compounds. The direction of glycone evolution depends on the presence/absence or number and position of sulfate and acetoxy groups, type of sugar units and their (non)linear structure, as well as position of methyl group. For example, Apodida are considered as the most primitive sea cucumbers due to the presence of 3-O-methyl Glc-A in the glycone and 8(9) double bond in the aglycone moiety. Among Holothuriida, Bohadschia is the most primitive genus due to the presence of non-sulfated glycosides and functional CT.

In summary, studying the evolutionary pattern of structure-function relationships of holothurian's triterpene glycosides helps to understand their chemical-structural diversity, taxonomic distribution, ecological function, as well as bioactivity of the molecules, which can lead to a more targeted and efficient assessment of MNPs with novel pharmacological activities.

Acknowledgment The authors acknowledge funding by the BMBF via the Ginaico project, project number 16GW0106.We also thank the reviewers and editor for valuable comments which helped to improve the manuscript.

\section{Appendix}

This article is related to the YOUMARES 9 conference session no. 9: "Biodiversity of Benthic Holobionts: Chemical Ecology and Natural Products Chemistry in the Spotlight." The original Call for Abstracts and the abstracts of the presentations within this session can be found in the Appendix "Conference Sessions and Abstracts", Chapter "7 Biodiversity of Benthic Holobionts: Chemical Ecology and Natural Products Chemistry in the Spotlight", of this book.

\section{References}

Abraham TJ, Nagarajan J, Shanmugam SA (2002) Antimicrobial substances of potential biomedical importance from holothurian species. Indian J Mar Sci 31:161-164

Afiyatullov SS, Tishchenko LY, Stonik VA et al (1985) Structure of cucumarioside $G_{1}$ - A new triterpene glycoside from the holothurian Cucumaria fraudatrix. Chem Nat Compd 21:228-232. https:// doi.org/10.1007/BF00714918

Agafonova IG, Aminin DL, Avilov SA et al (2003) Influence of Cucumariosides upon Intracellular $\left[\mathrm{Ca}^{2+}\right] \mathrm{i}$ and Lysosomal Activity of Macrophages. J Agric Food Chem 51:6982-6986. https://doi. org/10.1021/jf034439x

Al Marzouqi N, Iratni R, Nemmar A et al (2011) Frondoside A inhibits human breast cancer cell survival, migration, invasion and the growth of breast tumor xenografts. Eur J Pharmacol 668:25-34. https://doi.org/10.1016/j.ejphar.2011.06.023

Al Shemaili J, Mensah-Brown E, Parekh K et al (2014) Frondoside A enhances the antiproliferative effects of gemcitabine in pancreatic cancer. Eur J Cancer 50:1391-1398. https://doi.org/10.1016/j. ejca.2014.01.002

Althunibat OY, Ridzwan BH, Taher M et al (2013) Antioxidant and cytotoxic properties of two sea cucumbers, Holothuria edulis Lesson and Stichopus horrens Selenka. Acta Biol Hung 64(1):1020. https://doi.org/10.1556/ABiol.64.2013.1.2

Amidi S, Hashemi Z, Motallebi A et al (2017) Identification of (Z)-2,3diphenylacrylonitrile as anti-cancer molecule in Persian gulf sea cucumber Holothuria parva. Mar Drugs 15:1-14. https://doi. org/10.3390/md15100314 
Amini E, Nabiuni M, Baharara J et al (2014) Hemolytic and cytotoxic effects of saponin like compounds isolated from Persian Gulf brittle star (Ophiocoma erinaceus). J Coast Life Med 2:614-620. https:// doi.org/10.12980/JCLM.2.2014JCLM-2014-0056

Aminin DL (2016) Immunomodulatory properties of sea cucumber triterpene glycosides. In: Gopalakrishnakone P, Haddad V Jr, Tubaro A et al (eds) Marine and Freshwater Toxins. Springer, Dordrecht, pp 382-397

Aminin DL, Agafonova IG, Fedorov SN (1995) Biological activity of disulphated polyhydroxysteroids from the pacific brittle star Ophiopholis aculeata. Comp Biochem Physiol Part C Pharmacol Toxicol Endocrinol 112C:201-204. https://doi. org/10.1016/0742-8413(95)02012-8

Aminin DL, Agafonova IG, Berdyshev EV et al (2001) Immunomodulatory properties of cucumariosides from the edible Far-Eastern holothurian Cucumaria japonica. J Med Food 4:127135. https://doi.org/10.1089/109662001753165701

Aminin DL, Pinegin BV, Pichugina LV et al (2006) Immunomodulatory properties of Cumaside. Int Immunopharmacol 6:1070-1082. https://doi.org/10.1016/j.intimp.2006.01.017

Aminin DL, Agafonova IG, Kalinin VI et al (2008) Immunomodulatory properties of frondoside A, a major triterpene glycoside from the north Atlantic commercially harvested sea cucumber Cucumaria frondosa. J Med Food 11:443-453. https://doi.org/10.1089/ jmf.2007.0530

Aminin DL, Silchenko AS, Avilov SA et al (2010) Immunomodulatory action of monosulfated triterpene glycosides from the sea cucumber Cucumaria okhotensis: stimulation of activity of mouse peritoneal macrophages. Nat Prod Commun 5:1877-1880

Aminin DL, Zaporozhets TA, Avilov S et al (2011) Radioprotective properties of cumaside, a complex of triterpene glycosides from the sea cucumber Cucumaria japonica and cholestrol. Nat Prod Commun 6:587-592

Aminin DL, Menchinskaya ES, Pisliagin EA et al (2015) Anticancer activity of sea cucumber triterpene glycosides. Mar Drugs 13:12021223. https://doi.org/10.3390/md13031202

Andriyashchenko PV, Levina EV, Kalinovskii AI (1996) Steroid compounds from the Pacific starfishes Luidia quinaria and Distolasterias elegans CA125:86975. Russ Chem Bull 45:455-458. https://doi. org/10.1007/BF01433994

Anisimov MM, Fronert EB, Kuznetsova TA et al (1973) The toxic effect of triterpene glycosides from Stichopus japonicus selenka on early embryogenesis of the sea urchin. Toxicon 11:109-111. https:// doi.org/10.1016/0041-0101(73)90163-3

Anisimov MM, Shcheglov VV, Stonik VA et al (1974) The toxic effect of cucumarioside C from Cucumaria fraudatrix on early embryogenesis of the sea urchin. Toxicon 12:327-329

Anisimov MM, Prokofieva NG, Korotkikh LY et al (1980) Comparative study of cytotoxic activity of triterpene glycosides from marine organisms. Toxicon 18:221-223

Anisimov MM, Aminin DL, Rovin YG et al (1983) On the resistance of the cells of the sea cucumber Stichopus japonicus on the action of endotoxinstichoposide A. Dokl AN SSSR 270:991-993

Antonov A, Avilov S, Kalinovsky A (2008) Triterpene glycosides from Antarctic sea cucumbers. 1. Structure of Liouvillosides $A_{1}, A_{2}, A_{3}$, $\mathrm{B}_{1}$, and $\mathrm{B}_{2}$ from the sea cucumber Staurocucumis liouvillei: new procedure for separation of highly polar glycoside fractions and taxonomic revision. J Nat 71:1677-1685. https://doi.org/10.1021/ $\mathrm{np} 800173 \mathrm{c}$

Antonov AS, Avilov SA, Kalinovsky AI et al (2009) Triterpene glycosides from antarctic sea cucumbers. 2. structure of Liouvillosides $\mathrm{A}_{1}, \mathrm{~A}_{2}, \mathrm{~A}_{3}$ from the sea cucumber Achlionice violaecuspidata (=Rhipidothuria racowitzai). J Nat Prod 72:33-38

Antonov AS, Avilov SA, Kalinovsky AI et al (2011) Triterpene glycosides from Antarctic sea cucumbers III. Structures of liouvillosides $\mathrm{A}_{4}$ and $\mathrm{A}_{5}$, two minor disulphated tetraosides containing
3-O-methylquinovose as terminal monosaccharide units from the sea cucumber Staurocucumis liouvillei (Vaney). Nat Prod Res 25:1324-1333. https://doi.org/10.1080/14786419.2010.531017

Attoub S, Arafat K, Gélaude A et al (2013) Frondoside A Suppressive Effects on Lung Cancer Survival, Tumor Growth, Angiogenesis, Invasion, and Metastasis. PLoS One 8:1-10. https://doi.org/10.1371/ journal.pone. 0053087

Auria MVD, Riccio R, Minale L et al (1987) Novel marine steroid sulphates from Pacific Ophiuroids. Org Chem 52:3947-3952. https:// doi.org/10.1021/jo00227a001

Avilov SA, Kalinovsky AI, Stonik VA (1991a) Two new triterpene glycosides from the holothurian Duasmodactyla kurilensis. Chem Nat Compd 27:188-192

Avilov SA, Stonik VA, Kalinovskii AI (1991b) Structures of four new triterpene glycosides from the holothurian Cucumaria japonica. Chem Nat Compd 26:670-675. https://doi.org/10.1007/ BF00630079

Avilov SA, Kalinin VI, Makarieva TN et al (1994) Structure of cucumarioside $G_{2}$, a novel nonholostane glycoside from the sea cucumber Eupentacta fraudatrix. J Nat Prod 57:1166-1171. https:// doi.org/10.1021/np50110a007

Avilov SA, Kalinovsky AI, Kalinin VI et al (1997) Koreoside A, a new nonholostane triterpene glycoside from the sea cucumber Cucumaria koraiensis. J Nat Prod 60:808-810. https://doi. org/10.1021/np970152g

Avilov SA, Drozdova OA, Kalinin VI et al (1998) Frondoside C, a new nonholostane triterpene glycoside from the sea cucumber Cucumaria frondosa: structure and cytotoxicity of its desulfated derivative. Sect Title Carbohydrates 76:137-141. https://doi. org/10.1139/cjc-76-2-137

Avilov SA, Antonov AS, Drozdova OA et al (2000a) Triterpene glycosides from the far eastern sea cucumber Pentamera calcigera II: Disulfated glycosides. J Nat Prod 63:1349-1355. https://doi. org/10.1021/np000002x

Avilov SA, Antonov AS, Drozdova OA et al (2000b) Triterpene glycosides from the Far-Eastern sea cucumber Pentamera calcigera. 1. Monosulphated glycosides and cytotoxicity of their unsulfated derivatives. J Nat Prod 63:65-71. https://doi.org/10.1021/ np9903447

Avilov SA, Antonov AS, Silchenko AS et al (2003) Triterpene glycosides from the Far Eastern sea cucumber Cucumaria conicospermium. J Nat Prod 66:910-916. https://doi.org/10.1021/ np030005k

Avilov SA, Silchenko AS, Antonov AS et al (2008) Synaptosides A and A1, triterpene glycosides from the sea cucumber Synapta maculata containing 3-O-methylglucuronic acid and their cytotoxic activity against tumor cells. J Nat Prod 71:525-531

Bahrami Y, Franco C (2015) Structure Elucidation of New Acetylated Saponins, Lessoniosides A, B, C, D, and E, and Non-Acetylated Saponins, Lessoniosides $\mathrm{F}$ and $\mathrm{G}$, from the Viscera of the Sea Cucumber Holothuria lessoni. Mar Drugs 13:597-617. https://doi. org/10.3390/md13010597

Bahrami Y, Zhang W, Franco C (2014) Discovery of novel saponins from the viscera of the sea cucumber Holothuria lessoni. Mar Drugs 12:2633-2667. https://doi.org/10.3390/md12052633

Bahrami Y, Franco CMM, Benkendorff K (2016) Acetylated triterpene glycosides and their biological activity from holothuroidea reported in the past six decades. Mar Drugs 14:1-38. https://doi.org/10.3390/ md14080147

Batrakov SG, Girshovich ES, Drozhzhina NS (1980) Triterpene glycosides with antifungal activity isolated from the sea cucumber, Cucumaria japonica. Antibiotiki 25:408-411

Beauregard KA, Truong NT, Zhang H et al (2001) The Detection and Isolation of a Novel Antimicrobial Peptide from an Echinoderm, Cucumaria frondosa. Adv Exp Med Biol 484:55-62. https://doi. org/10.1007/978-1-4615-1291-2 
Berdyshev DV, Glazunov VP, Novikov VL (2007) 7-Ethyl-2,3,5,6,8pentahydroxy-1,4-naphthoquinone (echinochrome A): A DFT study of the antioxidant mechanism. 1. Interaction of echinochrome $A$ with hydroperoxyl radical. Russ Chem Bull 56:413-429. https:// doi.org/10.1007/s11172-007-0067-3

Bhakuni DS, Rawat DS (2005) Bioactive Marine Natural Products. Springer, Dordrecht/Publishers, New Dehli

Bhatnagar S, Dudouet B, Ahond A et al (1985) Invertebres marins du lagon Neocaledonien IV. Saponines et sapogenines d'une holothurie, Actinopyga flammea. Bull Soc Chim Fr:124-129

Blunt JW, Carroll AR, Copp BR et al (2018) Marine natural products. Nat Prod Rep 35:8-53

Bondoc KGV, Lee H, Cruz LJ et al (2013) Chemical fingerprinting and phylogenetic mapping of saponin congeners from three tropical holothurian sea cucumbers. Comp Biochem Physiol B Biochem Mol Biol 166:182-193. https://doi.org/10.1016/j.cbpb.2013.09.002

Bordbar S, Anwar F, Saari N (2011) High-value components and bioactives from sea cucumbers for functional foods - A review. Mar Drugs 9:1761-1805. https://doi.org/10.3390/md9101761

Borsig L, Wang L, Cavalcante MCM et al (2007) Selectin blocking activity of a fucosylated chondroitin sulfate glycosaminoglycan from sea cucumber: Effect on tumor metastasis and neutrophil recruitment. J Biol Chem 282:14984-14991. https://doi.org/10.1074/jbc. M610560200

Bruno I, Minale L, Pizza C et al (1984) Starfish saponins. Part 14. Structures of the steroidal glycoside sulphated from the starfish Marthasterias glacialis. J Chem Soc Perkin Trans I 0: 1875-1883

Bruno I, D’Auria MV, Iorizzi M et al (1992) Marine eicosanoids: Occurrence of 8,11,12-trihydroxylated eicosanoic acids in starfishes. Experientia 48:114-115. https://doi.org/10.1007/BF01923622

Bryan PJ, Mcclintock JB, Hopkins TS (1997) Structural and chemical defenses of echinoderms from the northern Gulf of Mexico. Exp Mar Biol Ecol 210:173-186

Candia Carnevali MD, Bonasoro F (2001) Introduction to the biology of regeneration in echinoderms. Microsc Res Tech 55:365-368. https://doi.org/10.1002/jemt.1184

Careaga VP, Muniain C, Maier MS (2011) Patagonicosides B and C, two antifungal sulphated triterpene glycosides from the sea cucumber Psolus patagonicus. Chem Biodivers 8:467-475

Careaga VP, Bueno C, Muniain C et al (2014) Pseudocnoside A, a new cytotoxic and antiproliferative triterpene glycoside from the sea cucumber Pseudocnus dubiosus leoninus. Nat Prod Res 28:213220. https://doi.org/10.1080/14786419.2012.751596

Caulier G, Van Dyck S, Gerbaux P et al (2011) Review of saponin diversity in sea cucumbers belonging to the family Holothuriidae. SPC Beche-de-mer Inf Bull 31:48-54

Chanley JD, Ledeen R, Wax J et al (1959) Holothurin. I. The Isolation, Properties and Sugar Components of Holothurin A. Am Chem Soc 81:5180-5183. https://doi.org/10.1021/ja01528a040

Chen LC, Lin YY, Jean YH et al (2014) Anti-inflammatory and analgesic effects of the marine-derived compound comaparvin isolated from the crinoid: Comanthus bennetti. Molecules 19:14667-14686. https://doi.org/10.3390/molecules190914667

Cheng G, Zhang X, Tang H-F et al (2006) Asterosaponin 1, a cytostatic compound from the starfish Culcita novaeguineae, functions by inducing apoptosis in human glioblastoma U87MG cells. J Neurooncol 79:235-241. https://doi.org/10.1007/ s11060-006-9136-y

Chludil HD, Muniain CC, Seldes AM et al (2002a) Cytotoxic and antifungal triterpene glycosides from the Patagonian sea cucumber Hemoiedema spectabilis. J Nat Prod 65:860-865. https://doi. org/10.1021/np0106236

Chludil HD, Seldes AM, Maier MS (2002b) Antifungal steroidal glycosides from the Patagonian starfish Anasterias minuta: Structure - activity correlations. J Nat Prod 65:153-157. https://doi. org/10.1021/np010332x
Chovolou Y, Ebada SS, Wätjen W et al (2011) Identification of angular naphthopyrones from the Philippine echinoderm Comanthus species as inhibitors of the NF- $\mathrm{kB}$ signaling pathway. Eur J Pharmacol 657:26-34. https://doi.org/10.1016/j.ejphar.2011.01.039

Clemente S, Hernández JC, Montaño-Moctezuma G et al (2013) Predators of juvenile sea urchins and the effect of habitat refuges. Mar Biol 160:579-590. https://doi.org/10.1007/s00227-012-2114-3

Comin MJ, Maier MS, Roccatagliata AJ et al (1999) Evaluation of the antiviral activity of natural sulphated polyhydroxysteroids and their synthetic derivatives and analogs. Steroids 64:335-340. https://doi. org/10.1016/S0039-128X(99)00016-1

Croteau R, Kutchan TM, Lewis NG (2000) Natural products (Secondary Metabolites). Biochem Mol Biol Plants 7:1250-1318. https://doi. org/10.1016/j.phytochem.2011.10.011

Cuong NX, Vien LT, Hanh TTH et al (2015) Cytotoxic triterpene saponins from Cercodemas anceps. Bioorg Med Chem Lett 25:31513156. https://doi.org/10.1016/j.bmcl.2015.06.005

Cuong NX, Vien LT, Hoang L et al (2017) Cytotoxic triterpene diglycosides from the sea cucumber Stichopus horrens. Bioorg Med Chem Lett 27:2939-2942. https://doi.org/10.1016/j.bmcl.2017.05.003

D'Auria MV, Riccio R, Minale L (1985) Ophioxanthin, a new marine carotonoid sulphate from the Ophiuroid Ophioderma longicaudum. Tetrahedron Lett 26:1871-1872

D'Auria MV, Riccio R, Minale L et al (1987) Novel marine steroid sulphates from pacific ophiuroids. J Org Chem 52(18):3947-3952. https://doi.org/10.1021/jo00227a001

D'Auria MV, Maria I, Minale L et al (1990) Starfish saponins part 40. Structures of two new Asterosaponins from the starfish Patritia miniata: Patirioside A, and Patirioside B. J Chem Soc Perkin Trans I $1: 1019-1023$

D’Auria MV, Minale L, Riccio R (1993) Polyoxygenated Steroids of Marine Origin. Chem Rev 93:1839-1895. https://doi.org/10.1021/ cr00021a010

Dai Y, Yu B (2015) Total synthesis of astrosterioside A, an antiinflammatory asterosaponin. Chem Commun 51:13826-13829. https://doi.org/10.1039/C5CC04734J

Dang NH, Van Thanh N, Van Kiem P et al (2007) Two New Triterpene Glycosides from the Vietnamese Sea Cucumber Holothuria scabra. Arch Pharm Res 30:1387-1391. https://doi.org/10.1007/ BF02977361

De Correa RS, Duque C, Riccio R et al (1985) Starfish saponins, Part 21. Steroidal glycosides from the starfish Oreaster Reticulatus. J Nat Prod 48:751-755. https://doi.org/10.1021/np50041a006

De Marino S, Iorizzi M, Zollo F et al (2000) Three new asterosaponins from the starfish Goniopecten demonstrans. European J Org Chem 2000:4093-4098. https://doi.org/10.1002/10990690(200012)2000:24<4093::AID-EJOC4093>3.0.CO;2-M

De Marino S, Borbone N, Iorizzi M et al (2003) Bioactive asterosaponins from the starfish Luidia quinaria and Psilaster cassiope. Isolation and structure characterization by two-dimensional NMR spectroscopy. J Nat Prod 66:515-519. https://doi.org/10.1021/np0205046

De Moncerrat Iñiguez-Martinez AM, Guerra-Rivas G, Rios T et al (2005) Triterpenoid oligoglycosides from the sea cucumber Stichopus parvimensis. J Nat Prod 68:1669-1673. https://doi. org/10.1021/np050196m

De Riccardis F, Giovannitti B, Iorizzi M, Minale L, Riccio R, Debitus C, De FBR (1991) Sterol Composition of the "Living Fossil" Crinoid Gymnocrinus richeri. Comp Biochem Physiol B Comp Biochem 100:647-651

De Simone F, Dini A, Minale L et al (1980) The Sterols of the Asteroid Echinaster sepositus. Comp Biochem Physiol B Biochem Mol Biol 66:351-357

De Simone F, Dini A, Finamore E et al (1981) Starfish saponins. Part 5. Structure of sepositoside A, a novel steroidal cyclic glycoside from the starfish Echinaster sepositus. J Chem Soc Perkin Trans I 1:1855-1862. https://doi.org/10.1039/P19810001855 
de Vivar M, Maier M, Seldes AM (1999) Polar metabolites from the Antarctic starfish Labidiaster annulatus. An des la Asoc Quim Argentina 87:247-253

Demeyer M, De WJ, Caulier G et al (2014) Molecular diversity and body distribution of saponins in the sea star Asterias rubens by mass spectrometry. Comp Biochem Physiol B Biochem Mol Biol 168:111. https://doi.org/10.1016/j.cbpb.2013.10.004

Dong G, Xu T, Yang B et al (2011) Chemical constituents and bioactivities of starfish. Chem Biodivers 8:740-791. https://doi.org/10.1002/ cbdv.200900344

Drozdova OA, Avilov SA, Kalinovskii AI et al (1993) New glycosides from the holothurian Cucumaria japonica. Chem Nat Compd 29:200-205

Drozdova OA, Avilov SA, Kalinin VI et al (1997) Cytotoxic triterpene glycosides from far-eastern sea cucumbers belonging to the genus Cucumaria. Liebigs Ann 1997:2351-2356. https://doi.org/10.1002/ jlac. 199719971125

Du L, Xu J, Xue Y et al (2015) Cerebrosides from sea cucumber ameliorates cancer-associated cachexia in mice by attenuating adipose atrophy. J Funct Foods 17:352-363. https://doi.org/10.1016/j. jff.2015.05.040

Duan J, Ishida M, Aida K et al (2016) Dietary cerebroside from sea cucumber (Stichopus japonicus): absorption and effects on skin barrier and cecal short-chain fatty acids. J Agric Food Chem 64:70147021. https://doi.org/10.1021/acs.jafc.6b02564

Dubois M-A, Noguchi Y, Higuchi R et al (1988) Structures of two new oligoglycoside sulfates: Pectinioside $\mathrm{C}$ and pectinioside D. Liebigs Ann 1988:495-500. https://doi.org/10.1002/jlac.198819880603

Duffy JE, Hay ME (2001) The ecology and evolution of marine consumer-prey interactions. In: Bertness MD, Hay ME, Gaines SD (eds) Marine community ecology. Sinauer Associates, Sunderland, pp 131-157

Elbandy M, Rho JR, Afifi R (2014) Analysis of saponins as bioactive zoochemicals from the marine functional food sea cucumber Bohadschia cousteaui. Eur Food Res Technol 238:937-955. https:// doi.org/10.1007/s00217-014-2171-6

Esmat AY, Said MM, Soliman AA et al (2013) Bioactive compounds, antioxidant potential, and hepatoprotective activity of sea cucumber (Holothuria atra) against thioacetamide intoxication in rats Nutrition 29:258-267. https://doi.org/10.1016/j.nut.2012.06.004

Farshadpour F, Gharibi S, Taherzadeh M et al (2014) Antiviral activity of Holothuria sp. a sea cucumber against herpes simplex virus type 1 (HSV-1). Eur Rev Med Pharmacol Sci 18:333-337

Fedorov SN, Shubina LK, Kicha AA et al (2008) Proapoptotic and Anticarcinogenic Activities of Leviusculoside G from the Starfish Henricia leviuscula and Probable Molecular Mechanism. Nat Prod Commun 3:1575-1580

Fedorov SN, Dyshlovoy SA, Kuzmich AS et al (2016) In vitro anticancer activities of some triterpene glycosides from holothurians of Cucumariidae, Stichopod, Psolidae, Holothuriidae, and Synaptidae families. Nat Prod Commun 11:1239-1242

Feng Y, Khokhar S, Davis RA (2017) Crinoids: ancient organisms, modern chemistry. Nat Prod Rep 34:571-584. https://doi. org/10.1039/C6NP00093B

Fieser LF, Fieser M (1956) Organic chemistry. Reinhold, New York

Finamore E, Minale L, Riccio R et al (1991) Novel marine polyhydroxylated steroids from the starfish Myxoderma platyacanthurn. J Org Chem 56:1146-1153. https://doi.org/10.1021/jo00003a043

Findlay JA, Agarwal VK (1983) Aglycones from the saponin of the starfish Asterias vulgaris. J Nat Prod 46:876-880. https://doi. org/10.1021/np50030a008

Findlay JA, He ZQ (1991) Polyhydroxylated steroidal glycosides from the starfish Asterias forbesi. J Nat Prod 54:428-435. https://doi org/10.1021/np50074a013

Findlay JA, Jaseja M, Burnell DJ (1987) Major saponins from the starfish Asterias forbesi. Complete structures by nuclear mag- netic resonance methods. Can J Chem 65:1384-1391. https://doi. org/10.1139/v87-234

Findlay JA, Findlay A, Findlay A et al (1989) Forbeside E: a novel sulphated sterol glycoside from Asterias forbesi. Can J Chem 67:2078-2080

Findlay JA, He Z-Q, Blackwell B (1990) Minor saponins from the starfish Asterias forbesi. Can J Chem 68:1215-1217. https://doi. org/10.1139/v90-188

Findlay JA, Yayli N, Radics L (1992) Novel sulfated oligosaccharides from the sea cucumber cucumaria frondosa. J Nat Prod 55:93-101. https://doi.org/10.1021/np50079a014

Folmer F, Jaspars M, Solano G et al (2009) The inhibition of TNF$\alpha$-induced NF- $\kappa B$ activation by marine natural products. Biochem Pharmacol 78:592-606. https://doi.org/10.1016/j.bcp.2009.05.009

Francis G, Kerem Z, Makkar HPS et al (2002) The biological action of saponins in animal systems: a review. Br J Nutr 88:587. https://doi. org/10.1079/BJN2002725

Garneau FX, Harvey C, Simard JL et al (1989) The distribution of asterosaponins in various body components of the starfish Leptasterias polaris. Comp Biochem Physiol B Biochem Mol Biol 92:411-416. https://doi. org/10.1016/0305-0491(89)90302-7

Ghanbari R, Ebrahimpour A, Abdul-Hamid A et al (2012) Actinopyga lecanora hydrolysates as natural antibacterial agents. Int J Mol Sci 13:16796-16811. https://doi.org/10.3390/ijms131216796

Ghannoum MA, Rice LB (1999) Antifungal agents: Mode of action, mechanisms of resistance, and correlation of these mechanisms with bacterial resistance. Clin Microbiol Rev 12:501-517. doi:10.1.1.322-6182

Girard M, Bélanger J, ApSimon JW et al (1990) Frondoside A. A novel triterpene glycoside from the holothurian Cucumaria frondosa. Can J Chem 68:11-18. https://doi.org/10.1139/v90-003

Gorshkov BA, Gorshkova IA, Stonik VA et al (1982) Effect of marine glycosides on adenosinetriphosphatase activity. Toxicon 20:655658. https://doi.org/10.1016/0041-0101(82)90059-9

Gorshkova IA, Gorshkov BA, Stonik VA (1989) Inhibition of rat brain $\mathrm{Na}^{+}-\mathrm{K}^{+}$-ATPase by triterpene glycosides from holothurians. Toxicon 27:927-936. https://doi.org/10.1016/0041-0101(89)90104-9

Gorshkova IA, Kalinin VI, Gorshkov BA et al (1999) Two different modes of inhibition of the rat brain $\mathrm{Na}^{+}, \mathrm{K}^{+}$-ATPase by triterpene glycosides, psolusosides $\mathrm{A}$ and $\mathrm{B}$ from the Holothurian Psolus fabricii. Comp Biochem Physiol C Pharmacol Toxicol Endocrinol 122:101-108. https://doi.org/10.1016/ S0742-8413(98)10085-3

Gowda NM, Goswami U, Khan MI (2008) T-antigen binding lectin with antibacterial activity from marine invertebrate, sea cucumber (Holothuria scabra): Possible involvement in differential recognition of bacteria. J Invertebr Pathol 99:141-145. https://doi. org/10.1016/j.jip.2008.04.003

Grishin Y, Besednova NN, Stonik VA et al (1990) The regulation of hemopoesis and immunogenesis by triterpene glycosides from holothurians. Radiobiologija 30:556

Guenther J, Wright AD, Burns K et al (2009) Chemical antifouling defences of sea stars: Effects of the natural products hexadecanoic acid, cholesterol, lathosterol and sitosterol. Mar Ecol Prog Ser 385:137-149. https://doi.org/10.3354/meps08034

Guo D, Xiong Y (2009) Preparation and characterization of Holothuria nobilis saponins nobiliside A freeze-dried liposome CA152:19119. Dier Junyi Daxue Xuebao 30:202-207

Han C, Qi J, Ojika M (2006) Structure-activity relationships of novel neuritogenic steroid glycosides from the Okinawan starfish Linckia laevigata. Bioorg Med Chem 14:4458-4465. https://doi. org/10.1016/j.bmc.2006.02.032

Han C, Qi J, Ojika M (2007a) Linckosides M-Q: Neuritogenic steroid glycosides from the Okinawan starfish Linckia laevigata. J Nat Med 61:138-145. https://doi.org/10.1007/s11418-006-0107-6 
Han H, Yi YH, Li L et al (2007b) A new triterpene glycoside from sea cucumber Holothuria leucospilota. Chinese Chem Lett 18:161164. https://doi.org/10.1016/j.cclet.2006.12.027

Han H, Yi Y, La M et al (2008a) Studies on antifungal and antitumor activities of scabraside A, B from Holothuria scabra Jaeger. Zhongguo Yaolixue Tongbao 24:1111-1112

Han H, Yi YH, Liu BS et al (2008b) Leucospilotaside C, a new sulphated triterpene glycoside from sea cucumber Holothuria leucospilota. Chinese Chem Lett 19:1462-1464. https://doi.org/10.1016/j. cclet.2008.09.051

Han H, Yi Y-H, Li L et al (2009a) Triterpene Glycosides from Sea Cucumber Holothuria leucospilota. Chin J Nat Med 7:346-350. https://doi.org/10.3724/SP.J.1009.2009.00346

Han H, Yi Y, Li L et al (2009b) Antifungal active triterpene glycosides from sea cucumber Holothuria scabra. Acta Pharmaceutica Sinica 44(6):620-624

Han H, Xu Q-Z, Tang H-F et al (2010a) Cytotoxic Holostane-Type Triterpene Glycosides from the Sea Cucumber Pentacta quadrangularis. Planta Med 76:1900-1904. https://doi.org/10.105 5/s-0030-1249854

Han H, Zhang W, Yi YH et al (2010b) A novel sulphated holostane glycoside from sea cucumber Holothuria leucospilota. Chem Biodivers 7:1764-1769. https://doi.org/10.1002/cbdv.200900094

Han H, Xu QZ, Yi YH et al (2010c) Two new cytotoxic disulphated holostane glycosides from the sea cucumber Pentacta quadrangularis. Chem Biodivers 7:158-167. https://doi.org/10.1002/ cbdv.200800324

Han H, Li L, YiY et al (2012) Triterpene Glycosides from Sea Cucumber Holothuria scabra with Cytotoxic Activity. Chinese Herb Med 4:183-188. https://doi.org/10.3969/j.issn.1674-6384.2012.03.002

Harvey C, Garneau FX, Himmelman JH (1987) Chemodetection of the predatory seastar Leptasterias polaris by the whelk Buccinum undatum. Mar Ecol Prog Ser 40:79-86

Hatakeyama T, Kamine T, Konishi Y et al (1999) Carbohydratedependent hemolytic activity of the conjugate composed of a C-type lectin, CEL-I, and an amphiphilic $\alpha$-helical peptide, 43- $\beta$ Ala2. Biosci Biotechnol Biochem 63:1312-1314. https://doi.org/10.1271/ bbb.63.1312

Haug T, Kjuul AK, Styrvold OB et al (2002) Antibacterial activity in Strongylocentrotus droebachiensis (Echinoidea), Cucumaria frondosa (Holothuroidea), and Asterias rubens (Asteroidea). J Invertebr Pathol 81:94.102. https://doi.org/10.1016/ S0022-2011(02)00153-2

Hegde VR, Chan TM, Pu H et al (2002) Two selective novel triterpene glycosides from sea cucumber, Theleonata ananas: inhibitors of chemokine receptor-5. Bioorganic Med Chem Lett 12:3203-3205

Herencia F, Ubeda A, Ferrandiz ML et al (1998) Anti-inflammatory activity in mice of extracts from mediterranean marine invertebrates. Pharmacol Lett 62:115-120

Hickman CP, Roberts L, Larson A (2001) Integrated principles of zoology. Mosby Publishers, St. Louis

Higuchi R, Fujita M, Matsumoto S et al (1996) Isolation and structure of four new steroid glycoside Di-0-sulphates from the starfish Asteropecten latespinosus. Liebigs Ann 1996:837-840

Honda M, Igarashi T, Komori T (1990) Structure of Pectinioside C: determination of the stereochemistry of the $\mathrm{C}-17$ side chain of the steroidal aglycone. Liebigs Ann 1990:547-553

Honey-Escandón M, Arreguín-Espinosa R, Solís-Marín FA et al (2015) Biological and taxonomic perspective of triterpenoid glycosides of sea cucumbers of the family Holothuriidae (Echinodermata, Holothuroidea). Comp Biochem Physiol Part B Biochem Mol Biol 180:16-39. https://doi.org/10.1016/j.cbpb.2014.09.007

Hu X-Q, Wang YM, Wang JF et al (2010) Dietary saponins of sea cucumber alleviate orotic acid-induced fatty liver in rats via PPAR $\alpha$ and SREBP-1c signaling. Lipids Health Dis 9:25. https://doi. org/10.1186/1476-511X-9-25
Hu S, Chang Y, He M et al (2014a) Fucosylated chondroitin sulfate from sea cucumber improves insulin sensitivity via activation of PI3K/PKB pathway. J Food Sci 79:H1424-H1427. https://doi. org/10.1111/1750-3841.12465

Hu S, Xu L, Shi D et al (2014b) Eicosapentaenoic acid-enriched phosphatidylcholine isolated from Cucumaria frondosa exhibits antihyperglycemic effects via activating phosphoinositide 3-kinase/ protein kinase B signal pathway. J Biosci Bioeng 117:457-463. https://doi.org/10.1016/j.jbiosc.2013.09.005

Huang N, Wu MY, Zheng CB et al (2013) The depolymerized fucosylated chondroitin sulfate from sea cucumber potently inhibits HIV replication via interfering with virus entry. Carbohydr Res 380:6469. https://doi.org/10.1016/j.carres.2013.07.010

Husni A, Shin IS, You S et al (2009) Antioxidant Properties of Water and Aqueous Ethanol Extracts and Their Crude Saponin Fractions from a Far-eastern Sea Cucumber, Stichopus japonicus. Food Sci Technol 18:419-424

Hwang IH, Kim WD, Kim SJ et al (2011) Asterosaponins Isolated from the Starfish Asterias amurensis. Chem Pharm Bull 59:78-83

Hwang IH, Kulkarni R, Yang MH et al (2014) Complete NMR assignments of undegraded asterosaponins from Asterias amurensis. Arch Pharm Res 37:1252-1263. https://doi.org/10.1007/ s12272-014-0374-9

Ikeda Y, Inagaki M, Yamada K et al (2009) Isolation and structure of a galactocerebroside from the sea cucumber Bohadschia argus. Chem Pharm Bull (Tokyo) 57:315-317. https://doi.org/10.1248/ cpb.57.315

Ikegami S, Kamiya Y, Tamura S (1973) Studies on Asterosaponins-V: A novel steroid conjugate, 5 alfa-PREGN-9(11)-ENE-3beta,6alfaDIOL-20-1-3-Sulfate, from a starfish saponin. Asterosaponin A. Tetrahedron 29:1807-1810

Inagaki M (2008) Structure and biological activity of glycosphingolipids from starfish and feather stars. Yakugaku zasshi 128(8):11871194. https://doi.org/10.1248/yakushi.128

Inagaki M, Nakata T, Higuchi R (2006) Isolation and structure of a galactocerebroside molecular species from the starfish Culcita novaeguineae. Chem Pharm Bull 54:260-261. https://doi. org/10.1248/cpb.54.260

Inagaki M, Shiizaki M, Hiwatashi T et al (2007) Constituents of Crinoidea. 5. Isolation and structure of a new glycosyl inositolphosphoceramide-type ganglioside from the feather star Comanthina schlegeli. Chem Pharm Bull (Tokyo) 55:1649-1651. https://doi.org/10.1248/cpb.55.1649

Iorizzi M, Minale L, Riccio R et al (1986) Starfish saponins, part 23. Steroidal glycosides from the starfish Halityle regularis. J Nat Prod 49:67-78. https://doi.org/10.1021/np50043a007

Iorizzi M, Minale L, Riccio R et al (1991) Starfish Saponins, Part 46. Steroidal Glycosides and Polyhydroxysteroids from the Starfish Culcita novaeguineae. J Nat Prod 54:1254-1264. https://doi. org/10.1021/np50077a003

Iorizzi M, Minale L, Riccio R et al (1992) Starfish saponins, 48. isolation of fifteen sterol constituents (six glycosides and nine polyhydroxysteroids) from the starfish Solaster borealis. J Nat Prod 55:866-877. https://doi.org/10.1021/np50085a005

Iorizzi M, De Riccardis F, Minale L et al (1993) Starfish saponins, 52. Chemical constituents from the starfish Echinaster brasiliensis. J Nat Prod 56:2149-2162. https://doi.org/10.1021/np50102a018

Iorizzi M, Bifulco G, De Riccardis F et al (1995) Starfish saponins, part 53. A reinvestigation of the polar steroids from the starfish Oreaster reticulatus: Isolation of sixteen steroidal oligoglycosides and six polyhydroxysteroids. J Nat Prod 58:10-26. https://doi.org/10.1021/ np50115a002

Ishida H, Hirota Y, Nakazawa H (1993) Effect of sub-skinning concentrations of saponin on intracellular $\mathrm{Ca}^{2+}$ and plasma membrane fluidity in cultured cardiac cells. BBA - Biomembr 1145:58-62. https://doi.org/10.1016/0005-2736(93)90381-9 
Ismail H, Lemriss S, Ben Aoun Z et al (2008) Antifungal activity of aqueous and methanolic extracts from the Mediterranean sea cucumber, Holothuria polii. J Mycol Med 18:23-26. https://doi. org/10.1016/j.mycmed.2008.01.002

Itakura Y, Komori T (1986) Biologically Active Glycosides from Asteroidea, X. Steroid Oligoglycosides from the Starfish Acanthaster planci L., 3. Structures of Four New Oligoglycoside Sulfates. Liebigs Ann 1986:499-508. https://doi.org/10.1002/ jlac. 198619860308

Ivanchina NV, Kich A, Kalinovsky A et al (2000) Hemolytic polar steroidal constitutents of the starfish Aphelasterias japonica. J Nat Prod 63(8):1178-1181. https://doi.org/10.1021/np000030f

Ivanchina NV, Kicha AA, Kalinovsky AI et al (2004) Absolute configuration of side chains of polyhydroxylated steroidal compounds from the starfish Henricia derjugini. Russ Chem Bull 53:2639-2642. https://doi.org/10.1007/s11172-005-0166-y

Ivanchina NV, Malyarenko TV, Kicha AA et al (2005) Asterosaponin ophidianoside $\mathrm{F}$ from gonads of the Far-Eastern starfish Aphelasterias japonica. Chem Nat Compd 41:481-482. https://doi. org/10.1007/s10600-005-0187-7

Ivanchina NV, Kicha AA, Kalinovsky AI et al (2006) Polar steroidal compounds from the Far Eastern starfish Henricia leviuscula. J Nat Prod 69:224-228. https://doi.org/10.1021/np050373j

Ivanchina NV, Malyarenko TV, Kicha AA et al (2011) Structures and cytotoxic activities of two new asterosaponins from the antarctic starfish Diplasterias brucei. Russ J Bioorganic Chem 37:499-506. https://doi.org/10.1134/S1068162011030083

Ivanchina NV, Kalinovsky AI, Kicha AA et al (2012) Two New Asterosaponins from the Far Eastern Starfish Lethasterias fusca. Nat Prod Commun 7(7):853-858

Ivanchina NV, Malyarenko TV, Kicha AA et al (2017) A new steroidal glycoside granulatoside $\mathrm{C}$ from the starfish Choriaster granulatus, unexpectedly combining structural features of polar steroids from several different marine invertebrate phyla. Nat Prod Commun $12: 1585-1588$

Ivanchina NV, Kicha AA, Malyarenko TV et al (2018) Granulatosides D, E and other polar steroid compounds from the starfish Choriaster granulatus. Their immunomodulatory activity and cytotoxicity. Nat Prod Res:1-8. https://doi.org/10.1080/1478641 9.2018.1463223

Iyengar EV, Harvell CD (2001) Predator deterrence of early developmental stages of temperate lecithotrophic asteroids and holothuroids. J Exp Mar Bio Ecol 264:171-188. https://doi.org/10.1016/ S0022-0981(01)00314-8

Janakiram NB, Mohammed A, Zhang Y et al (2010) Chemopreventive effects of Frondanol A5, a Cucumaria frondosa extract, against rat colon carcinogenesis and inhibition of human colon cancer cell growth. Cancer Prev Res 3:82-91. https://doi.org/10.1158/19406207.CAPR-09-0112

Janakiram NB, Mohammed A, Rao CV (2015) Sea cucumbers metabolites as potent anti-cancer agents. Mar Drugs 13:2909-2923. https:// doi.org/10.3390/md13052909

Jangoux M (1984) Diseases of echinoderms. Helgoländer Meeresun 37:207-216. https://doi.org/10.1007/BF01989305

Jeong SH, Kim HK, Song IS et al (2014) Echinochrome a protects mitochondrial function in cardiomyocytes against cardiotoxic drugs. Mar Drugs 12:2922-2936. https://doi.org/10.3390/ md12052922

Jia Z, Song Y, Tao S et al (2016) Structure of sphingolipids from sea cucumber Cucumaria frondosa and structure-specific cytotoxicity against human hepg2 cells. Lipids 51:321-334. https://doi. org/10.1007/s11745-016-4128-y

Jiang Z-H, Schmidt RR (1992) The hexasaccharide moiety of pectinioside. Liebigs Ann 1992:75-982

Jiang Z-H, Han X-B, Schmidt RR (1993) Synthesis of the sulfated steroidal glycosides Forbeside E3 and E1. Liebigs Ann 1993:1179-1184
Jiao H, Shang X, Dong Q et al (2015) Polysaccharide constituents of three types of sea urchin shells and their anti-inflammatory activities. Mar Drugs 13:5882-5900. https://doi.org/10.3390/md13095882

Jin W, Rinehart KL, Jares-Erijman EA (1994) Ophidiacerebrosides: cytotoxic glycosphingolipids containing a novel sphingosine from a sea star. J Org Chem 59:144-147. https://doi.org/10.1021/ jo00080a023

Kalinin VI (2000) System-theoretical (Holistic) approach to the modelling of structural-functional relationships of biomolecules and their evolution: an example of triterpene glycosides from sea cucumbers (Echinodermata, Holothurioidea). J Theor Biol 206:151-168. https://doi.org/10.1006/jtbi.2000.2110

Kalinin VI, Stonik VA (1996) Application of morphological trends of evolution to phylogenetic interpretation of chemotaxonomic data. J Theor Biol 180:1-10. https://doi.org/10.1006/jtbi.1996.0073

Kalinin VI, Kalinovskii AI, Stonik VA et al (1989a) Structure of psolusoside B- A nonholostane triterpene glycoside of the holothurian genus Psolus. Chem Nat Compd 25:311-317

Kalinin VI, Stonik VA, Kalinovskii AI et al (1989b) Structure of pseudostichoposide A- The main triterpene glycoside from the holothurian Pseudostichopus trachus. Chem Nat Compd 25:577-582

Kalinin VI, Avilov SA, Kalinovskii AI et al (1992a) Cucumarioside $\mathrm{G}_{3}$ - A minor triterpene glycoside from the holothurian Eupentacta fraudatrix. Chem Nat Compd 28:635-636

Kalinin VI, Avilov SA, Kalinovskii AI et al (1992b) Cucumarioside $\mathrm{G}_{4}$ - A new triterpenglycoside from the holothurian Eupentacta fraudatrix. Chem Nat Compd 28:600-603

Kalinin VI, Prokofieva NG, Likhatskaya GN et al (1996) Hemolytic activities of triterpene glycosides from the holothurian order Dendrochirotida: Some trends in the evolution of this group of toxins. Toxicon 34:475-483. https://doi. org/10.1016/0041-0101(95)00142-5

Kalinin VI, Avilov SA, Kalinina EY et al (1997) Structure of eximisoside A, a novel triterpene glycoside from the Far-Eastern sea cucumber Psolus eximius. J Nat Prod 60:817-819. https://doi.org/10.1021/ np9701541

Kalinin VI, Aminin DL, Avilov SA et al (2008) Triterpene glycosides from sea cucucmbers (Holothurioidea, Echinodermata). Biological activities and functions. In: Atta-Ur-Rahman (ed) Studies in natural products chemistry (Bioactive natural products) Elsevier Science Publisher 35:135-196

Kalinin VI, Avilov SA, Silchenko AS et al (2015) Triterpene glycosides of sea cucumbers (Holothuroidea, Echinodermata) as taxonomic markers. Nat Prod Commun 10:21-26

Kalinin VI, Silchenko AS, Avilov SA (2016) Taxonomic Significance and Ecological Role of Triterpene Glycosides from Holothurians. Biol Bull 43:616-624. https://doi.org/10.1134/S1062359016060108

Kalinovskii AI, Levina EV, Stonik VA et al (2004) Steroid polyols from the far eastern starfish Henricia sanguinolenta and H. leviuscula leviuscula. Russ J Bioorganic Chem 30:191-195. https://doi. org/10.1023/B:RUBI.0000023107.90150.09

Kaluzhskiy LA, Shkel TV, Ivanchina NV et al (2017) Structural Analogues of Lanosterol from Marine Organisms of the Class Asteroidea as potential inhibitors of human and Candida albicans lanosterol 14 $\alpha$-demethylases. Nat Prod Commun 12:1843-1846

Karin M, Yamamoto Y, Wang QM (2004) The IKK NF-кB system: A treasure trove for drug development. Nat Rev Drug Discov 3:17-26. https://doi.org/10.1038/nrd1279

Karleskint G, Turner R, Small JW (2010) In: Brooks/Cole, Belmont (ed) Introduction to marine biology, 3rd edn

Kaul P (1986) Marine pharmacology: bioactive molecules from the sea. Annu Rev Pharmacol Toxicol 26:117-142. https://doi.org/10.1146/ annurev.pharmtox.26.1.117

Kawase O, Ohno O, Suenaga K et al (2016) Immunological Adjuvant Activity of Pectinioside A, the Steroidal Saponin from the Starfish Patiria pectinifera. Nat Prod Commun 11:605-606 
Kenta G, Tatsuya S, Hideki T et al (2015) Total Synthesis and Neuritogenic Activity Evaluation of Ganglioside PNG-2A from the Starfish Protoreaster nodosus. Asian J Org Chem 4:1160-1171. https://doi.org/10.1002/ajoc.201500282

Kicha AA, Kallnovsky AI, Levina E et al (1983) Asterosaponin $P_{1}$ from the starfish Patria pectinifera. Tetrahedron Lett 24:3893-3896

Kicha AA, Kalinovsky AI, Levina EV et al (1985) Culcitoside $C_{1}$ from starfishes Culcita novaeguineae and Linckia guildingi. Chem Nat Compd 21:760-762

Kicha AA, Kalinovskii AI, Andrishchenko PV (1986) Culcitosides $\mathrm{C}_{2}$ and $\mathrm{C}_{3}$ from the starfish Culcita novaeguineae. Chem Nat Compd 22:557-560. https://doi.org/10.1007/BF00599260

Kicha AA, Kalinovsky AI, Gorbach NV et al (1993) New polyhydroxysteroids from the far-eastern starfish Henricia sp. Chem Nat Compd 29:206-210

Kicha AA, Ivanchina NV, Kalinovsky AI et al (2000) Asterosaponin P2 from the Far-Eastern starfish Patiria (asterina) pectinifera. Russ Chem Bull 49:1794-1795

Kicha AA, Ivanchina NV, Kalinovsky AI et al (2001) Sulphated steroid compounds from the starfish Aphelasterias japonica of the Kuril population. Russ Chem Bull 50:724-727

Kicha AA, Ivanchina NV, Stonik VA (2004) Seasonal variations in polyhydroxysteroids and related glycosides from digestive tissues of the starfish Patiria (=Asterina) pectinifera. Comp Biochem Physiol Part B Biochem Mol Biol 139:581-585. https://doi.org/10.1016/j. cbpc.2004.06.011

Kicha AA, Ivanchina NV, Kalinovsky A et al (2007a) Sulfated steroid glycosides from the Viet Namese starfish Linckia laevigata. Chem Nat Compd 43:76-80. https://doi.org/10.1007/s10600-007-0036-y

Kicha AA, Ivanchina NV, Kalinovsky A et al (2007b) New neuritogenic steroid glycosides from the Vietnamese starfish Linckia laevigata. Nat Prod Commun 2:41-46

Kicha AA, Ivanchina NV, Kalinovsky AI et al (2007c) Four new steroid glycosides from the Vietnamese starfish Linckia laevigata. Russ Chem Bull 56:823-830. https://doi.org/10.1007/s11172-007-0123-z

Kicha AA, Ivanchina NV, Huong TTT et al (2010a) Two new asterosaponins, archasterosides A and B, from the Vietnamese starfish Archaster typicus and their anticancer properties. Bioorganic Med Chem Lett 20:3826-3830. https://doi.org/10.1016/j. bmcl.2010.04.005

Kicha AA, Ivanchina NV, Huong TTT et al (2010b) Minor asterosaponin archasteroside $\mathrm{C}$ from the starfish Archaster typicus. Russ Chem Bull 59:2133-2136. https://doi.org/10.1007/s11172-010-0368-9

Kicha AA, Kalinovsky AI, Ivanchina NV et al (2011) Four new asterosaponins, hippasteriosides A - D, from the Far Eastern starfish Hippasteria kurilensis. Chem Biodivers 8:166-175. https://doi. org/10.1002/cbdv.200900402

Kitagawa I, Kobayashi M (1977) On the structure of the major saponin from Acanthaster planci. Tetrahedron Lett 2:859-862

Kitagawa I, Kobayashi M (1978) Saponin and Sapogenol. XXVI. Steroidal saponins from the starfish Acanthaster planci L. (Crown of Thorns). (2). Structure of the major saponin Thornasteroside A. Chem Pharm Bull 26:1864-1873. https://doi. org/10.1248/cpb.37.3229

Kitagawa I, Sugawara T, Yosioka I et al (1976) Saponin and sapogenol. XIV. Antifungal glycosides from the sea cucumber Stichopus japonicus Selenka: 1. Structure of Stichopogenin $\mathrm{A}_{4}$, the genuine aglycone of holotoxin A. Chem Pharm Bull 24:266-274. https://doi. org/10.1248/cpb.37.3229

Kitagawa I, Nishino T, Kyogoku Y (1979) Structure of holothurin A a biologically active triterpene-oligoglycoside from the sea cucumber Holothuria leucospilota Brandt. Tetrahedron Lett:1419-1422. https://doi.org/10.1016/S0040-4039(01)86166-9

Kitagawa I, Inamoto T, Fuchida M et al (1980) Structures of Echinoside $\mathrm{A}$ and $\mathrm{B}$, two antifungal oligoglycosides from the sea cucumber
Actinopyga echinites (JAEGER). Chem Pharm Bull 28:1651-1653. https://doi.org/10.1248/cpb.37.3229

Kitagawa I, Kobayashi K, Inamoto T et al (1981a) The structure of six antifungal oligoglycosides, Stichlorosides $\mathrm{A}_{1}, \mathrm{~A}_{2}, \mathrm{~B}_{1}, \mathrm{~B}_{2}, \mathrm{C}$, and $\mathrm{C}_{2}$, from the sea cucumber Stichopus chloronotus (Brandt). Chem Pharm Bull 29:2387-2391

Kitagawa I, Kobayashi K, Inamoto T et al (1981b) Stichlorogenol and Dehydrostichlorogenol, Genuine Aglycones of Stichlorosides $A_{1}$, $\mathrm{B}_{1}, \mathrm{C}_{1}$ and $\mathrm{A}_{2}, \mathrm{~B}_{2}, \mathrm{C}_{2}$, from the Sea Cucumber Stichopus Chloronotus (BRANDT). Biosci Biotechnol Biochem 29:1189-1192. https://doi. org/10.1248/cpb.37.3229

Kitagawa I, Kobayashi M, Hori M et al (1981c) Structures of four new triterpenoidal oligoglycosides, Bivittoside A, B, C, and D, from the sea cucumber Bohadschia bivittata MITSUKURI. Chem Pharm Bull 29:282-285. https://doi.org/10.1093/jxb/erl177

Kitagawa I, Nishino T, Kobayashi M et al (1981d) Marine Natural Products. VIII. Bioactive triterpene- oligoglycosides from the sea cucumber Holothuria leucospilota (Brandt). Structure of holothurin A. Chem Pharm Bull 29:1951-1956. https://doi.org/10.1248/ cpb.37.3229

Kitagawa I, Kobayashi M, Inamoto $\mathrm{T}$ et al (1985) Marine Natural Products. XIV. Structures of echinosides A and B, antifungal lanostane oligosides from the sea cucumber Actinopyga echinites (Jaeger). Chem Pharm Bull (Tokyo) 33:5214-5224

Kitagawa I, Kobayashi M, Hori M et al (1989) Marine Natural Producs. XVIII. Four lanostane- type triterpene oligoglycosides, bivittosides $\mathrm{A}, \mathrm{B}, \mathrm{C}$, and D from the Okinawan sea cucumber Bohadschia bivittata (Mitsukuri). Chem Pharm Bull 37:61-67

Kobayashi M, Hori M, Kan K et al (1991) Marine Natural Products. XXVII Distribution of Lanostane-type triterpene oligoglycosides in ten kind of Okinawan sea cucumbers. Chem Pharm Bull 39:22822287. https://doi.org/10.1248/cpb.37.3229

Kornprobst J-M, Sallenave C, Barnathan G (1998) Sulfated compounds from marine organisms. Comp Biochem Physiol B Biochem Mol Biol 119:1-51. https://doi.org/10.1016/S0305-0491(97)00168-5

Kropp RK (1982) Responses of Five Holothurian Species to Attacks by a Predatory Gastropod Tonna perdix. Pacific Sci 36:445-452

Kubanek J, Pawlik JR, Eve TM et al (2000) Triterpene glycosides defend the Caribbean reef sponge Erylus formosus from predatory fishes. Mar Ecol Prog Ser 207:69-77. https://doi.org/10.3354/ meps207069

Kumar R, Chaturvedi AK, Shukla PK et al (2007) Antifungal activity in triterpene glycosides from the sea cucumber Actinopyga lecanora. Bioorg Med Chem Lett 17:4387-4391. https://doi.org/10.1016/j. bmcl.2006.12.052

Kuznetsova TA, Anisimov MM, Popov AM et al (1982a) A comparative study in vitro of physiological activity of triterpene glycosides of marine invertebrates of echinoderm type. Comp Biochem Physiol Part C Pharmacol Toxicol Endocrinol 73:41-43. https://doi. org/10.1016/0306-4492(82)90165-4

Kuznetsova TA, Kalinovskaya NI, Kalinovskii AI et al (1982b) Glycosides of marine invertebrates. XIV. Structure of holothurin $\mathrm{B}_{1}$ from the holothurian Holothuria floridana. Chem Nat Compd 18:449-451. https://doi.org/10.1007/BF00579642

La M-P, Li C, Li L et al (2012) New bioactive sulfated alkenes from the sea cucumber Apostichopus japonicus. Chem Biodivers 9:11661171. https://doi.org/10.1002/cbdv.201100324

Laille M, Gerald F, Debitus C (1998) In vitro antiviral activity on dengue virus of marine natural products. C Cell Mol life Sci 54:167170. https://doi.org/10.1007/s000180050138

Lakshmi V, Saxena A, Mishra SK et al (2008) Spermicidal Activity of Bivittoside D from Bohadschia vitiensis. Arch Med Res 39:631638. https://doi.org/10.1016/j.arcmed.2008.06.007 
Lakshmi V, Srivastava S, Mishra SK, Shukla PK (2012) Antifungal activity of bivittoside-D 14 from Bohadschia vitiensis (Semper). Nat Prod Res 26(10):913-918

Lawrence PG, Harold PL, Francis OG (1957) Antibiotics and Chemotherapy 4(1):1980-1989

Lee J, Wang W, Hong J et al (2007) A new 2,3-dimethyl butenolide from the brittle star Ophiomastix mixta. Chem Pharm Bull (Tokyo) 55:459-461. https://doi.org/10.1248/cpb.55.459

Levina EV, Kalinovskii AI, Andriyaschenko PV et al (1987) Steroid Glycosides from the starfish Echinaster sepositus. Chem Nat Compd 23:206-209

Levina EV, Andriyaschenko PV, Stonik VA et al (1996) Ophiuroidtype steroids in starfish of the genus Pteraster. Comp Biochem Physiol B Biochem Mol Biol 114:49-52. https://doi. org/10.1016/0305-0491(95)02121-3

Levina EV, Andriyashchenko PV, Kalinovskii AI et al (2001) Steroid compounds from the Pacific starfish Lysastrosoma anthosticta. Russ Chem Bull 50:313-315. https://doi.org/10.1023/A:1009503006894

Levina EV, Kalinovskii AI, Stonik VA et al (2003) Steroidal polyols from Far-Eastern starfishes Henricia sanguinolenta and H. leviuscula leviuscula. Russ Chem Bull 52:1623-1628. https://doi.org/10. 1023/A:1025613714119

Levina EV, Kalinovskii AI, Andriyashchenko PV et al (2004) A new steroidal glycoside phrygioside A and its aglycone from the starfish Hippasteria phrygiana. Russ Chem Bull 53:2634-2638. https://doi. org/10.1007/s11172-005-0165z

Levina EV, Kalinovsky AI, Andriyashenko PV et al (2005) Phrygiasterol, a cytotoxic cyclopropane-containing polyhydroxysteroid, and related compounds from the Pacific starfish Hippasteria phrygiana. J Nat Prod 68:1541-1544. https://doi.org/10.1021/np049610t

Levina EV, Kalinovskii AI, Dmitrenok PS (2007) Steroid compounds from the Far East starfish Pteraster obscurus and the ophiura Asteronyx loveni. Bioorg Khim 33:365-370. https://doi. org/10.1134/S1068162007030119

Levina EV, Kalinovsky A, Dmitrenok PS (2009) Bioactive Steroidal Sulphates from the Ambulakrums of the Pacific Starfish Lysastrosoma anthosticta. Nat Prod Commun 4:1041-1046

Levina EV, Kalinovsky A, Dmitrenok PS et al (2010) Two new steroidal saponins, Hylodoside A and Novaeguinoside Y, from the starfish Leptasterias hylodes reticulata and Culcita novaeguineae (Juvenile). Nat Prod Commun 5:1737-1742

Li C, Haug T, Styrvold OB et al (2008) Strongylocins, novel antimicrobial peptides from the green sea urchin, Strongylocentrotus droebachiensis. Dev Comp Immunol 32:1430-1440. https://doi. org/10.1016/j.dci.2008.06.013

Li M, Miao ZH, Chen Z et al (2010) Echinoside A, a new marinederived anticancer saponin, targets topoisomerase $2 \alpha$ by unique interference with its DNA binding and catalytic cycle. Ann Oncol 21:597-607. https://doi.org/10.1093/annonc/mdp335

Li Z, Chen G, Lu X et al (2013) Three new steroid glycosides from the starfish Asterina pectinifera. Nat Prod Res 27:1816-1822. https:// doi.org/10.1080/14786419.2012.761621

Liu HH, Ko WC, Hu ML (2002) Hypolipidemic effect of glycosaminoglycans from the sea cucumber Metriatyla scabra in rats fed a cholesterol-supplemented diet. J Agric Food Chem 50:3602-3606. https://doi.org/10.1021/jf020070k

Liu BS, Yi YH, Li L et al (2007) Arguside A: A new cytotoxic triterpene glycoside from the sea cucumber Bohadschia argus Jaeger. Chem Biodivers 4:2845-2851. https://doi.org/10.1002/cbdv.200790234

Liu BS, Yi YH, Li L et al (2008a) Argusides D and E, two new cytotoxic triterpene glycosides from the sea cucumber Bohadschia argus Jaeger. Chem Biodivers 5:1425-1433. https://doi.org/10.1002/ cbdv.200890131

Liu BS, Yi YH, Li L et al (2008b) Argusides B and C, two new cytotoxic triterpene glycosides from the sea cucumber Bohadschia argus
Jaeger. Chem Biodivers 5:1288-1297. https://doi.org/10.1002/ cbdv.200890115

Liu Y, Yan H, Wen K et al (2011) Identification of epidioxysterol from south China sea urchin Tripneustes gratilla Linnaeus and its cytotoxic activity. J Food Biochem 35:932-938. https://doi. org/10.1111/j.1745-4514.2010.00426.x

Liu X, Sun Z, Zhang M et al (2012) Antioxidant and antihyperlipidemic activities of polysaccharides from sea cucumber Apostichopus japonicus. Carbohydr Polym 90:1664-1670. https://doi. org/10.1016/j.carbpol.2012.07.047

Lu Y, Li H, Wang M et al (2018) Cytotoxic polyhydroxysteroidal glycosides from starfish Culcita novaeguineae. Mar Drugs 16:92. https:// doi.org/10.3390/md16030092

Ma N, Tang HF, Qiu F et al (2009a) A new polyhydroxysteroidal glycoside from the starfish Anthenea chinensis. Chinese Chem Lett 20:1231-1234. https://doi.org/10.1016/j.cclet.2009.05.012

Ma XG, Tang HF, Zhao CH et al (2009b) Two new 24-hydroxylated asterosaponins from Culcita novaeguineae. Chinese Chem Lett 20:1227-1230. https://doi.org/10.1016/J.CCLET.2009.05.031

Ma N, Tang HF, Qiu F et al (2010) Polyhydroxysteroidal glycosides from the starfish Anthenea chinensis. J Nat Prod 73:590-597. https://doi.org/10.1021/np9007188

Ma X, Kundu N, Collin PD et al (2012) Frondoside A inhibits breast cancer metastasis and antagonizes prostaglandin $\mathrm{E}$ receptors $\mathrm{EP}_{4}$ and $\mathrm{EP}_{2}$. Breast Cancer Res Treat 132:1001-1008. https://doi. org/10.1007/s10549-011-1675-z

Mackie AM, Singh HT, Owen JM (1977) Studies on the distribution, biosynthesis and function of steroidal saponins in echinoderms. Comp Biochem Physiol B Comp Biochem 56:9-14. https://doi. org/10.1016/0305-0491(77)90214-0

Maier MS (2008) Biological activities of sulfated glycosides from echinoderms. In: Atta-Ur-Rahman (ed) Studies in natural products Chemistry. Elsevier Science Publisher 35:311-354

Maier MS, Roccatagliata A, Seldes AM (1993) Two Novel Steroidal Glycoside Sulphates from the Starfish Cosmasterias lurida. J Nat Prod 56:939-942. https://doi.org/10.1021/np50096a020

Maier MS, Roccatagliata AJ, Kuriss A et al (2001) Two new cytotoxic and virucidal trisulphated triterpene glycosides from the antarctic sea cucumber Staurocucumis liouvillei. J Nat Prod 64:732-736. https://doi.org/10.1021/np000584i

Maltsev II, Stonik VA, Kalinovsky AI (1984) Triterpene glycosides from sea cucumber Stichopus japonicus Selenka. Comp Biochem Physiol B Comp Biochem 78:421-426

Maltsev II, Stekhova SI, Schentsova EB et al (1985) Antimicrobial activities of glycosides from the sea cucumbers of family Stichopodidae. Khim-Pharm Zhurn 19:54-56

Malyarenko TV, Kicha AA, Ivanchina NV et al (2010) Three new polyhydroxysteroids from the tropical starfish Asteropsis carinifera. Russ J Bioorganic Chem 36:755-761. https://doi.org/10.1134/ S1068162010060129

Malyarenko TV, Kicha AA, Ivanchina NV et al (2011) Cariniferosides A-F and other steroidal biglycosides from the starfish Asteropsis carinifera. Steroids 76:1280-1287. https://doi.org/10.1016/J. STEROIDS.2011.06.006

Malyarenko TV, Kicha AA, Ivanchina NV (2012) Asteropsiside A and other asterosaponins from the starfish Asteropsis carinifera. Russ Chem Bull 61:1986-1991. https://doi.org/10.1007/ s11172-012-0275-3

Malyarenko TV, Kicha AA, Ivanchina NV et al (2014) Asterosaponins from the Far Eastern starfish Leptasterias ochotensis and their anticancer activity. Steroids 87:119-127. https://doi.org/10.1016/j. steroids.2014.05.027

Malyarenko TV, Malyarenko OS, Ivanchina NV et al (2015) Four new sulfated polar steroids from the Far Eastern starfish Leptasterias ochotensis: Structures and activities. Mar Drugs 13:4418-4435. https://doi.org/10.3390/md13074418 
Malyarenko OS, Dyshlovoy SA, Kicha AA et al (2017) The inhibitory activity of Luzonicosides from the starfish Echinaster luzonicus against human melanoma cells. Mar Drugs 15:1-11. https://doi. org/10.3390/md15070227

Maoka T, Nakachi S, Kobayashi R et al (2015) A new carotenoid, 9Z,9'Ztetrahydroastaxanthin, from the sea cucumber Plesiocolochirus minutus. Tetrahedron Lett 56:5954-5955. https://doi.org/10.1016/j. tetlet.2015.09.060

Marques J, Vilanova E, Mourão PAS et al (2016) Marine organism sulphated polysaccharides exhibiting significant antimalarial activity and inhibition of red blood cell invasion by Plasmodium. Sci Rep 6:1-14. https://doi.org/10.1038/srep24368

Mats MN, Korkhov VV, Stepanov VR et al (1990) The contraceptive activity of triterpene glycosides-the total sum of holotoxins A1 and B1 and holothurin A in an experiment. Farmakol Toksikol 53:45-47

Mayer AMS, Hamann MT (2002) Marine pharmacology in 1999: compounds with antibacterial, anticoagulant, antifungal, anthelmintic, anti-inflammatory, antiplatelet, antiprotozoal and antiviral activities affecting the cardiovascular, endocrine, immune and nervous systems, and other misc. Comp Biochem Physiol 132:315-339. https:// doi.org/10.1007/s10126-003-0007-7

Mayer AMS, Glaser KB, Cuevas C et al (2010) The odyssey of marine pharmaceuticals: a current pipeline perspective. Trends Pharmacol Sci 31:255-265. https://doi.org/10.1016/j.tips.2010.02.005

Mayer AMS, Rodr AD, Taglialatela-Scafati O et al (2017) Marine pharmacology in 2012 - 2013: marine the immune and nervous systems, and other miscellaneous mechanisms of action. Mar Drugs 15:1-61. https://doi.org/10.3390/md15090273

Melek FR, Tadros MM, Yousif F et al (2012) Screening of marine extracts for schistosomicidal activity in vitro. Isolation of the triterpene glycosides echinosides A and B with potential activity from the Sea Cucumbers Actinopyga echinites and Holothuria polii. Pharm Biol 50:490-496. https://doi.org/10.3109/13880209.2011.615842

Menchinskaya ES, Pislyagin EA, Kovalchyk SN et al (2014) Antitumor activity of cucumarioside A2-2. Chemotherapy 59:181-191. https:// doi.org/10.1159/000354156

Miller A, Kerr A, Paulay G et al (2017) Moleculra phylogeny of extant Holothuroidae (Echinodermata). Mol Phylogenetics Evol 111:110 131. https://doi.org/10.1016/j.ympev.2017.02.014

Minale L, Pizza C, Zollo F (1983) Starfish saponins. Part 9. A novel 24-O-glycosidated steroid from the starfish Hacelia attenuata. Experientia 39:567-569

Minale L, Pizza C, Plomitallo A et al (1984a) Starfish saponins. XII. Sulphated steroid glycosides from the starfish Hacelia attenuata. Gazz Chim Ital 114:151-158

Minale L, Pizza C, Riccio R et al (1984b) Minor Polyhydroxylated Sterols from the Starfish Protoreaster nodosus. J Nat Prod 47:790795. https://doi.org/10.1021/np50035a006

Minale L, Pizza C, Riccio R et al (1984c) Starfish Saponins, XIII. Occurrence of Nodososide in the Starfish Acanthaster Planci and Linckia Laevigata. J Nat Prod 47:558. https://doi.org/10.1021/ np50033a037

Minale L, Riccio R, Squillace Greco O et al (1985) Starfish saponinsXVI. Composition of the steroidal glycoside sulphates from the starfish Luidia maculata. Comp Biochem Physiol B Biochem 80:113-118. https://doi.org/10.1016/0305-0491(85)90431-6

Minale L, Riccio R, Zollo F (1995) Structural Studies on Chemical Constituents of Echinoderms. Stud Nat Prod Chem 15:43-110

Minale L, Riccio R, De Simone F et al (1997) Starfish saponin II: 22,23-Epoxysteroids, minor genins from the starfish Echinaster sepositus. Tetrahedron Lett 20:645-648. https://doi.org/10.1038/ sj.onc. 1209954

Miyamoto T, Togawa K, Higuchi R et al (1990a) Constituents of holothuroidea, Isolation and structures of three triterpenoid aglycones, cucumechinol A, B, and C, from the sea cucumber Cucumaria echinata. Liebigs Ann 1990:39-42. https://doi.org/10.1002/jlac.199019900106
Miyamoto T, Togawa K, Higuchi R et al (1990b) Six newly identified biologically active triterpenoid glycoside sulfates from the sea cucumber Cucumaria echinata. Liebigs Ann 1990:453-460

Miyamoto T, Togawa K, Higuchi R (1992) Structures of four new triterpenoid oligoglycosides: DS-penaustrosides A, B, C, and D from the sea cucumber Pentacta australis. J Nat Prod 55:940-946. https:// doi.org/10.1021/np50085a014

Molinski TF, Dalisay DS, Lievens SL et al (2009) Drug development from marine natural products. Nat Rev Drug Discov 8:69-85. https://doi.org/10.1038/nrd2487

Mona MH, Omran NEE, Mansoor MA (2012) Antischistosomal effect of holothurin extracted from some Egyptian sea cucumbers. Pharm Biol 50:1144-1150. https://doi.org/10.3109/13880209.201 2.661741

Mondol MAM, Shin HJ, Rahman MA et al (2017) Sea cucumber glycosides: Chemical structures, producing species and important biological properties. Mar Drugs 15:317. https://doi.org/10.3390/ md 15100317

Moraes G, Northcote PT, Silchenko AS et al (2005) Mollisosides A, $\mathrm{B}_{1}$, and $\mathrm{B}_{2}$ : Minor triterpene glycosides from the New Zealand and south Australian sea cucumber Australostichopus mollis. J Nat Prod 68:842-847. https://doi.org/10.1021/np050049o

Mourão PAS, Guimarães MAM, Mulloy B (1998) Antithrombotic activity of a fucosylated chondroitin sulphate from echinoderm: Sulphated fucose branches on the polysaccharide account for its antithrombotic action. Br J Haematol 101:647-652. https://doi. org/10.1046/j.1365-2141.1998.00769.x

Muniain C, Centurion R, Careaga C et al (2008) Chemical ecology and bioactivity of triterpene glycosides from the sea cucumber Psolus patagonicus (Dendrochirotida: Psolidae). J Mar Biol Assoc UK 88(4):817-823

Murray AP, Muniaín C, Seldes AM et al (2001) Patagonicoside A: A novel antifungal disulfated triterpene glycoside from the sea cucumber Psolus patagonicus. Tetrahedron 57:9563-9568. https://doi. org/10.1016/S0040-4020(01)00970-X

Nance JM, Braithwaite LF (1979) The function of mucous secretions in the cushion star Pteraster tesselatus Ives. J Exp Mar Biol Ecol 40:259-266. https://doi.org/10.1016/0022-0981(79)90055-8

Ngoan BT, Hanh TTH, Vien LT et al (2015) Asterosaponins and glycosylated polyhydroxysteroids from the starfish Culcita novaeguineae and their cytotoxic activities. J Asian Nat Prod Res 17:1010-1017. https://doi.org/10.1080/10286020.2015.1041930

Nguyen TH, Um BH, Kim SM (2011) Two unsaturated fatty acids with Potent $\alpha$-Glucosidase inhibitory Activity purified from the body wall of sea cucumber (Stichopus japonicus). J Food Sci 76:208214. https://doi.org/10.1111/j.1750-3841.2011.02391.x

Nigrelli RF, Jakowska S (1960) Effects of Holothurin, a steroid saponin from the Bahamian sea cucumber (Actinopyga Agassizi), on various biological systems. Ann N Y Acad Sci 17:884-892. https://doi. org/10.1111/j.1749-6632.1960.tb26431.x

Nigrelli R, Zahl P (1952) Some biological characteristics of Holothurin. Exp Biol Med 81(2):379-380. https://doi. org/10.3181/00379727-81-19882

Nishikawa Y, Furukawa A, Shiga I et al (2015) Cytoprotective effects of lysophospholipids from sea cucumber Holothuria atra. PLoS One 10:1-14. https://doi.org/10.1371/journal.pone.0135701

Nuzzo G, Gomes BA, Amodeo P et al (2017) Isolation of chemigrene sesquiterpenes and absolute configuration of isoobtusadiene from the brittle star Ophionereis reticulata. J Nat Prod 80:3049-3053

Oda T, Shinmura N, Nishioka Y et al (1999) Effect of the Hemolytic Lectin CEL-III from Holothuroidea Cucumaria echinata on the ANS Fluorescence Responses in Sensitive MDCK and Resistant CHO Cells. J Biochem 125:713-720

Okano K, Ohkawa N, Ikegami S (1985) Structure of ovarian Asterosaponin-4, an inhibitor of spontaneous oocyte matura- 
tion from the Starfish Asterias amurensis. Agri Biol Chemi 49:2823-2826

Oleinikova GK, Kuznetsova TA (1983) Two-stage smith degradation of holothurin $\mathrm{B}_{1}$ from the holothurian Holothuria floridana. Chem Nat Compd 19:508-509. https://doi.org/10.1007/BF00575731

Oleinikova GK, Kuznetsova TA, Rovnykh NV et al (1982) Glycosides of marine invertebrates. XVIII. Holothurin $\mathrm{A}_{2}$ from the Caribbean holothurian Holothuria floridana. Chem Nat Compd 18:501-502

Omran NE, Khedr AM (2015) Structure elucidation, protein profile and the antitumor effect of the biological active substance extracted from sea cucumber Holothuria polii. Toxicol Ind Health 31:1-8. https://doi.org/10.1177/0748233712466135

Ozupek NM, Cavas L (2017) Triterpene glycosides associated antifouling activity from Holothuria tubulosa and $H$. polii. Reg Stud Mar Sci 13:32-41. https://doi.org/10.1016/j.rsma.2017.04.003

Paine RT (1969) A Note on Trophic Complexity and Community Stability. Am Nat 103:91-93

Palagiano E, Zollo F, Minale L et al (1996) Isolation of 20 glycosides from the starfish Henricia downeyae, collected in the Gulf of Mexico. J Nat Prod 59:348-354. https://doi.org/10.1021/np9601014

Palyanova NV, Pankova TM, Starostina MV et al (2013) Neuritogenic and neuroprotective effects of polar steroids from the far east starfishes Patiria pectinifera and Distolasterias nipon. Mar Drugs 11:1440-1455. https://doi.org/10.3390/md11051440

Pan K, Inagaki M, Ohno N et al (2010) Identification of sixteen new galactocerebrosides from the starfish Protoreaster nodosus. Chem Pharm Bull (Tokyo) 58:470-474. https://doi.org/10.1248/ cpb. 58.470

Pan K, Tanaka C, Inagaki M et al (2012) Isolation and structure elucidation of GM4-type gangliosides from the Okinawan starfish Protoreaster nodosus. Mar Drugs 10:2467-2480. https://doi. org/10.3390/md10112467

Park HY, Kim JY, Kim HJ et al (2009) Insecticidal and repelenet activities of crude saponin from the starfish Asterias amuerensis. Fish Sci Technol 12:1-5

Park J-I, Bae H-R, Kim CG et al (2014) Relationships between chemical structures and functions of triterpene glycosides isolated from sea cucumbers. Front Chem 2:1-14. https://doi.org/10.3389/ fchem.2014.00077

Paul VJ, Arthur KE, Ritson-Williams R et al (2007) Chemical Defenses: From Compounds to Communities Linked. Biol Bull 213:226-251

Peng Y, Zheng J, Huang R et al (2010) Polyhydroxy steroids and saponins from China sea starfish Asterina pectinifera. Chem Pharm Bull 58:856-858. https://doi.org/10.1248/cpb.58.856

Pereira MS, Mulloy B, Moura PAS (1999) Structure and Anticoagulant Activity of Sulphated Fucans. J Biol Chem 274:7656-7667. https:// doi.org/10.1074/jbc.M002422200

Pettit GR, Herald CL, Herald DL (1976) Antineoplastic agents XLV: Sea cucumber cytotoxic saponins. J Pharm Sci 65:1975-1976

Pettit GR, Hasler JA, Paull KD et al (1981) Antineoplastic Agents. 76. The Sea Urchin Strongylocentrotus droebachiensis. J Nat Prod 44:701-704. https://doi.org/10.1021/np50018a015

Pislyagin EA, Aminin DL, Silchenko AS et al (2014) Immunomodulatory action of triterpene glycosides isolated from the sea cucumber Actinocucumis typica. Structure-activity relationships. Nat Prod Commun Immunomodul 9:771-772

Pislyagin EA, Manzhulo IV, Gorpenchenko TY et al (2017) Cucumarioside $\mathrm{A}_{2-2}$ causes macrophage activation in mouse spleen. Mar Drugs 15:1-15. https://doi.org/10.3390/md15110341

Pizza C, Minale L, Laurent D (1985a) Starfish saponins: XXVII. Steroidal glycosides from the starfish Choriaster granulatus. Gazz Chim Ital 115:585-589

Pizza C, Pezzullo P, Minale L et al (1985b) Starfish saponins. Part 20. Two novel steroidal glycosides from the starfish Acanthaster planci (L). J Chem Res Synop 1985:76-77
Pocsidio GN (1983) The Mutagenicity Potential of Holothurin of Some Philippine Holothurin. Philipp J Sci 112:1-12

Polikarpova SI, Volkova ON, Sedov AM et al (1990) Cytogenetic study of the mutagenicity of cucumarioside. Genetika 26:1682-1685

Popov AM (2002) A comparative study of the hemolytic and cytotoxic activities of triterpenoids isolated from ginseng and sea cucumbers. Biol Bull 29:120-128. https://doi.org/10.1023/A:1014398714718

Popov A, Atopkina L, Samoshina NF et al (1994) Immunomodulating activity of tetracyclic triterpene glycosides of the dammarane and holostane series. Antibiot Khimioter 39:19-25

Popov RS, Avilov SA, Silchenko AS et al (2014) Cucumariosides $F_{1}$ and $F_{2}$, two new triterpene glycosides from the sea cucumber Eupentacta fraudatrix and their LC-ESI MS / MS identification in the star fish Patiria pectinifera, a predator of the sea cucumber. Biochem Syst Ecol 57:191-197. doi:https://doi.org/10.1016/j. bse.2014.08.009

Popov R, Ivanchina N, Kalinovsky A et al (2016) Aphelasteroside F, a new asterosaponin from the far eastern starfish Aphelasterias japonica. Nat Prod Commun 11:1247-1250

Prokof'eva NG, Chaikina EL, Kicha AA et al (2003) Biological activities of steroid glycosides from starfish. Comp Biochem Physiol Part B Biochem Mol Biol 134:695-701. https://doi.org/10.1016/ S1096-4959(03)00029-0

Qi J, Ojika M, Sakagami Y (2002) linckosides A and B, two new neuritogenic steroid glycosides from the okinawan starfish Linckia laevigata. Bioorg Med Chem 10:1961-1966. https://doi.org/10.1016/ S0968-0896(02)00006-8

Qi J, Ojika M, Sakagami Y (2004) Linckosides C-E, three new neuritogenic steroid glycosides from the Okinawan starfish Linckia laevigata. Bioorg Med Chem 12:4259-4265. https://doi.org/10.1016/j. bmc.2004.04.049

Qi J, Han C, Sasayama Y et al (2006) Granulatoside A, a starfish steroid glycoside, enhances PC12 cell neuritogenesis induced by nerve growth factor through an activation of MAP kinase. ChemMedChem 1:1351-1354. https://doi.org/10.1002/cmdc.200600190

Riccio R, De Simone E, Dini A et al (1981) Starfish saponins VI unique 22,23-epoxysteroidal cyclic glycosides, minor constituents from Echinaster sepositus. Tetrahedron Lett 22:1557-1560. https:// doi.org/10.1016/S0040-4039(01)90377-6

Riccio R, Dini A, Minale L et al (1982a) Starfish saponins VII. Structure of Luzonicoside, a further steroidal cyclic glycoside from the pacific starfish Echinaster Luzonicus. Experientia 38:68-70

Riccio R, Minale L, Pagonis S et al (1982b) A novel group of highly hydroxylated steroids from the starfish Protoreaster nodosus. Tetrahedron 38:3615-3622. https://doi.org/10.1016/ 0040-4020(82)80069-0

Riccio R, D'Auria MV, Minale L (1985a) Unusual sulfated marine steroids from the ophiuroid Ophioderma longicaudum. Tetrahedron 41:6041-6046. https://doi.org/10.1016/S0040-4020(01)91445-0

Riccio R, Greco OS, Minale L et al (1985b) Starfish saponins, part 18. steroidal glycoside sulfates from the starfish Linckia laevigata. J Nat Prod 48:97-101. https://doi.org/10.1021/np50037a017

Riccio R, Pizza C, Squillace-Greco O et al (1985c) Starfish saponins. Part 17. steroidal glycoside sulfates from the starfish Ophidiaster ophidianus (Lamarck), and Hacelia attenuata (Gray). J Chem Soc Perkin Trans I 1:655-660

Riccio R, Zollo F, Finamore E et al (1985d) Starfish saponins, 19. A novel steroidal glycoside sulphate from the starfishes Protoreaster nodosus and Pentaceraster alveolatus. J Nat Prod 48:266-272. https://doi.org/10.1021/np50038a011

Riccio R, D'Auria MV, Minale L (1986a) Two New Steroidal Glycoside Sulphates, Longicaudoside-A and -B, from the Mediterranean Ophiuroid Ophioderma longicaudum. J Org Chem 51:533-536. https://doi.org/10.1021/jo00354a025 
Riccio R, Greco OS, Minale L et al (1986b) Starfish saponins, part 28. steroidal glycosides from pacific starfishes of the genus Nardoa. J Nat Prod 49:1141-1143. https://doi.org/10.1021/np50048a036

Riccio R, Iorizzi M, Greco OS et al (1986c) Starfish Saponins, Part 22. Asterosaponins from the Starfish Halityle Regularis: A Novel 22,23-Epoxysteroidal Glycoside Sulfate. J Nat Prod 48:756-765. https://doi.org/10.1021/np50041a007

Riccio R, Iorizzi M, Minale L (1986d) Starfish Saponins. Isolation of Sixteen Steroidal Glycosides and Three Polyhydroxysteroids from the Mediterranean Starfish Coscinasterias Tenuispina. Bull des Sociétés Chim Belges 95:869-893. https://doi.org/10.1002/ bscb.19860950912

Riccio R, Iorizzi M, Minale L et al (1988) Starfish saponins. Part 34. Novel steroidal glycoside sulphates from the starfish Asterias amurensis. J Chem Soc Perkin Trans 1:1337-1347. https://doi. org/10.1039/P19880001337

Rideout JA, Smith NB, Sutherland MD (1979) Chemical defense of crinoids by polyketide sulphates. Experientia 35:1273-1274. https:// doi.org/10.1007/BF01963951

Ridzwan BH (2007) Sea cucumber: the Malaysian heritage. Research Centre, IULM, Kuala Lumpur

Roccatagliata AJ, Maier MS, Seldes AM (1994) Starfish saponins, part 2. Steroidal oligoglycosides from the starfish Cosmasterias lurida. J Nat Prod 57:747-754. https://doi.org/10.1021/np50108a010

Roccatagliata AJ, Maier MS, Seldes AM et al (1996) Antiviral sulphated steroids from the ophiuroid Ophioplocus januarii. J Nat Prod 59:887-889. https://doi.org/10.1021/np960171a

Rodriguez J, Riguera R (1989) Lefevreiosides: four novel triterpenoid glycosides from the sea cucumber Cucumaria lefevrei. ChemInform 21:2620-2636. https://doi.org/10.1002/chin.199014299

Rodriguez J, Castro R, Riguera R (1991) Holothurinosides: new antitumor non sulphated triterpenoid glycosides from the sea cucumber Holothuria forskali. Tetrahedron 47:4753-4762

Ruppert EE, Fox RS, Barnes RD (2004) Invertebrate zoology: a functional evolutionary approach. Thomson Brook/Cole, Belmont

Sallivan TD, Ladue KT, Nigrelli RF (1955) The effect of holothurin, a steroid saponin of animal origin, on Krebs-2 ascites tumors in Swiss mice. Zoologica 40:49-52

Sandvoss M, Pham H, Levsen K et al (2000) Isolation and structural elucidation of Steroid Oligoglycosides from the starfish Asterias rubens by means of direct online LC-NMR-MS hyphenation and One- and two-dimensional NMR investigations. Eur J Org Chem 2000:1253-1262

Sandvoss M, Preiss A, Levsen K et al (2003) Two new asterosaponins from the starfish Asterias rubens: Application of a cryogenic NMR probe head. Magn Reson Chem 41:949-954

Schoenmakers HJN (1979) In vitro biosynthesis of steroids from cholestrol by the ovaries and pyloric caeca of the starfish Asterias rubens. Comp Bochem Physiol B 63:179-184

Sedov AM, Shepeleva IB, Zakharova NS et al (1984) Effect of cucumarioside (a triterpene glycoside from the holothurian Cucumaria japonica) on the development of an immune response in mice to corpuscular pertussis vaccine. Zhurnal mikrobiologii, epidemiologii, i immunobiologii 9:100-104

Sedov AM, Apollonin AV, Sevast'ianova EK et al (1990) Stimulation of nonspecific antibacterial resistance of mice to opportunistic gram-negative microorganisms with triterpene glycosides from Holothuroidea. Antibiot Khimioter 35:23-26

Shang X, Liu X, Zhang J et al (2014) Traditional chinese medicine -Sea urchin. Mini-Rev Med Chem 14:537-542

Sharypov VF, Chumak AD, Stonik VA et al (1981) Glycosides of marine invertebrates. X. The structure of stichoposides A and B from the holothurians Stichopus cloronotus. Chem Nat Compd 17:139-142

Silchenko AS, Avilov SA, Antonov AA et al (2002) Triterpene glycosides from the deep-water North-Pacific sea cucumber Synallactes nozawai Mitsukuri. J Nat Prod 65:1802-1808. https://doi. org/10.1021/np0202881

Silchenko AS, Avilov SA, Kalinin VI et al (2004) Pseudostichoposide B - new triterpene glycoside with unprecedent type of sulfatation from the deep-water North-Pacific sea cucumber pseudostichopus trachus. Nat Prod Res 18:565-570. https://doi.org/10.1080/14786 410310001630591

Silchenko AS, Avilov SA, Antonov AS et al (2005a) Glycosides from the sea cucumber Cucumaria frondosa. III. Structure of frondosides $\mathrm{A}_{2-1}, \mathrm{~A}_{2-2}, \mathrm{~A}_{2-3}$, and $\mathrm{A}_{2-6}$, four new minor monosulphated triterpene glycosides. Can J Chem 83:21-27. https://doi.org/10.1139/v05-243

Silchenko AS, Avilov SA, Antonov AS et al (2005b) Glycosides from the sea cucumber Cucumaria frondosa. IV. Structure of frondosides $\mathrm{A}_{2-4}, \mathrm{~A}_{2-7}$, and $\mathrm{A}_{2-8}$, three new minor monosulphated triterpene glycosides. Can J Chem 83:2120-2126. https://doi.org/10.1139/v05-243

Silchenko AS, Stonik VA, Avilov SA et al (2005c) Holothurins $B_{2}, B_{3}$, and $\mathrm{B}_{4}$, new triterpene glycosides from Mediterranean sea cucumbers of the genus Holothuria. J Nat Prod 68:564-567. https://doi. org/10.1021/np049631n

Silchenko AS, Avilov SA, Antonov AS et al (2007a) Glycosides from the North Atlantic sea cucumber Cucumaria frondosa - Structures of five new minor trisulfated triterpene oligoglycosides, frondosides $\mathrm{A}_{7-1}, \mathrm{~A}_{7-2}, \mathrm{~A}_{7-3}, \mathrm{~A}_{7-4}$, and isofrondoside C. Can J Chem 85:626-636. https://doi.org/10.1139/v04-163

Silchenko AS, Avilov SA, Kalinin VI et al (2007b) Monosulfated triterpene glycosides from Cucumaria okhotensis Levin et Stepanov, a new species of sea cucumbers from Sea of Okhotsk. Bioorg Khim 33:81-90. https://doi.org/10.1134/S1068162007010098

Silchenko AS, Avilov SA, Kalinin VI et al (2008) Constituents of the sea cucumber Cucumaria okhotensis. Structures of okhotosides $\mathrm{B}_{1^{-}}$ $\mathrm{B}_{3}$ and cytotoxic activities of some glycosides from this species. Nat Prod 71:351-356. https://doi.org/10.1021/np0705413

Silchenko AS, Kalinovsky AI, Avilov SA et al (2012a) Triterpene glycosides from the sea cucumber Eupentacta fraudatrix. Structure and biological action of Cucumariosides $\mathrm{A}_{1}, \mathrm{~A}_{3}, \mathrm{~A}_{4}, \mathrm{~A}_{5}, \mathrm{~A}_{6}, \mathrm{~A}_{12}$ and $A_{15}$, seven new minor non-sulfated tetraosides and unprecedented 25-keto, 27-norholostane aglycone. Nat Prod Commun 7:517-525

Silchenko AS, Kalinovsky AI, Avilov SA et al (2012b) Triterpene Glycosides from the Sea Cucumber Eupentacta fraudatrix. Structure and Cytotoxic Action of Cucumariosides $\mathrm{A}_{2}, \mathrm{~A}_{7}, \mathrm{~A}_{9}, \mathrm{~A}_{10}$, $\mathrm{A}_{11}, \mathrm{~A}_{13}$ and $\mathrm{A}_{14}$, Seven New Minor Non-Sulfated Tetraosides and an Aglycone with an Uncommon 18-Hydroxy Group. Nat Prod Commun Triterpene 7:845-852

Silchenko AS, Kalinovsky AL, Avilov SA et al (2012c) Structures and cytotoxic properties of cucumariosides $\mathrm{H}_{2}, \mathrm{H}_{3}$ and $\mathrm{H}_{4}$ from the see cucumber Eupentacta fraudatrix. Nat Prod Res 26(19):1765-1774. https://doi.org/10.1080/14786419.2011.602637

Silchenko AS, Kalinovsky AL, Avilov SA et al (2012d) Triterpene glycosides from the sea cucumber Eupentacta fraudatrix. Structure and biological action of Cucumariosides $\mathrm{B}_{1}$, and $\mathrm{B}_{2}$, two new minor nonsulfated tetraosides and unprecedented 25-keto, 27-norholostane aglycone. Nat Prod Commun 7:517-525

Silchenko AS, Kalinovsky AI, Avilov SA et al (2013a) Triterpene glycosides from the sea cucumber Eupentacta fraudatrix. Structure and biological action of cucumariosides $\mathrm{I}_{1}, \mathrm{I}_{3}, \mathrm{I}_{4}$, three new minor disulfated pentaosides. Nat Prod Commun 8:1053-1058

Silchenko AS, Kalinovsky AI, Avilov SA et al (2013b) Structures and biological activities of typicosides $A_{1}, A_{2}, B_{1}, C_{1}$ and $C_{2}$, triterpene glycosides from the sea cucumber Actinocucumis typica. Nat Prod Commun 8:301-310

Silchenko AS, Kalinovsky AI, Avilov SA et al (2013c) Structure of cucumarioside $\mathrm{I}_{2}$ from the sea cucumber Eupentacta fraudatrix (Djakonov et Baranova) and cytotoxic and immunostimulatory activities of this saponin and relative compounds. Nat Prod Res 27:1776-1783. https://doi.org/10.1080/14786419.2013.778851 
Silchenko AS, Kalinovsky AI, Avilov SA et al (2013d) Triterpene glycosides from Antarctic sea cucumbers IV. Turquetoside A, a 3-O-methylquinovose containing disulfated tetraoside from the sea cucumber Staurocucumis turqueti (Vaney, 1906) (=Cucumaria spatha). Biochem Syst Ecol 51:45-49. https://doi.org/10.1016/j. bse.2013.08.012

Silchenko AS, Kalinovsky AI, Avilov SA et al (2013e) Structure and biological action of Cladolosides $\mathrm{B}_{1}, \mathrm{~B}_{2}, \mathrm{C}, \mathrm{C}_{1}, \mathrm{C}_{2}$ and $\mathrm{D}$, six new triterpene glycosides from the sea cucumber Cladolabes schmeltzii. Nat Prod Commun 8:1527-1534

Silchenko AS, Kalinovsky AI, Avilov SA et al (2014a) Structures of Violaceusosides C, D, E and G, Sulfated Triterpene Glycosides from the Sea Cucumber Pseudocolochirus violaceus (Cucumariidae, Dendrochirotida). Nat Prod Rep 9:391-399

Silchenko AS, Kalinovsky AI, Avilov SI et al (2014b) Kolgaosides A and B, Two New Triterpene Glycosides from the Arctic Deep Water Sea Cucumber Kolga hyalina (Elasipodida: Elpidiidae). Nat Prod Commun 9:1259-1264

Silchenko AS, Kalinovsky AI, Avilov et al (2014c) Triterpene glycosides from the sea cucumber Cladolabes schmeltzii. II. Structure and biological action of cladolosides A1-A6. Nat Prod Commun 9:1421-1429

Silchenko AS, Kalinovsky AI, Avilov SA et al (2015a) Colochirosides $\mathrm{B}_{1}, \mathrm{~B}_{2}, \mathrm{~B}_{3}$ and $\mathrm{C}$, novel sulfated triterpene glycosides from the sea cucumber Colochirus robustus (Cucumariidae, Dendrochirotida). NPC. Nat Prod Commun 10:1687-1694. https://doi. org/10.1080/13531040802284544

Silchenko AS, Kalinovsky AI, Avilov SA et al (2015b) Structures and biological activities of cladolosides $\mathrm{C}_{3}, \mathrm{E}_{1}, \mathrm{E}_{2}, \mathrm{~F}_{1}, \mathrm{~F}_{2}, \mathrm{G}$, $\mathrm{H}_{1}$ and $\mathrm{H}_{2}$, eight triterpene glycosides from the sea cucumber Cladolabes schmeltzii with one known and four new carbohydrate chains. Carbohydr Res 414:22-31. https://doi.org/10.1016/j. carres.2015.06.005

Silchenko AS, Kalinovsky AI, Avilov SA et al (2016a) Structures and biogenesis of fallaxosides $\mathrm{D}_{4}, \mathrm{D}_{5}, \mathrm{D}_{6}$ and $\mathrm{D}_{7}$, trisulfated non-holostane triterpene glycosides from the sea cucumber Cucumaria fallax. Molecules 21:2-13. https://doi.org/10.3390/ molecules 21070939

Silchenko AS, Kalinovsky AI, Avilov SA et al (2016b) Colochirosides $\mathrm{A}_{1}, \mathrm{~A}_{2}, \mathrm{~A}_{3}$, and $\mathrm{D}$, Four Novel Sulfated Triterpene Glycosides from the Sea Cucumber Colochirus robustus (Cucumariidae, Dendrochirotida). Nat Prod Commun 11:381-387

Silchenko AS, Kalinovsky AI, Avilov SA et al (2016c) Colochiroside $\mathrm{E}$, an unusual non-holostane triterpene sulfated trioside from the sea cucumber Colochirus robustus and evidence of the impossibility of a 7(8)-double bond Migration in lanostane derivatives having an 18(16)-lactone. Nat Prod Commun 11:741-746

Silchenko AS, Kalinovsky AI, Avilov SA et al (2017a) Cladolosides $\mathrm{I}_{1}, \mathrm{I}_{2}, \mathrm{~J}_{1}, \mathrm{~K}_{1}, \mathrm{~K}_{2}$ and $\mathrm{L}_{1}$, monosulfated triterpene glycosides with new carbohydrate chains from the sea cucumber Cladolabes schmeltzii. Carbohydr Res 445:80-87. https://doi.org/10.1016/j. carres.2017.04.016

Silchenko AS, Kalinovsky AI, Avilov SA et al (2017b) Nine new triterpene glycosides, magnumosides $\mathrm{A}_{1}-\mathrm{A}_{4}, \mathrm{~B}_{1}, \mathrm{~B}_{2}, \mathrm{C}_{1}, \mathrm{C}_{2}$ and $\mathrm{C}_{4}$, from the Vietnamese sea cucumber Neothyonidium (=Massinium) magnum: Structures and activities against tumor cells independently and in synergy with radioactive irradiation. Mar Drugs 15:1-22. https:// doi.org/10.3390/md15080256

Silchenko AS, Kalinovsky AI, Avilov SA et al (2018a) Cladolosides $\mathrm{O}, \mathrm{P}, \mathrm{P}_{1}-\mathrm{P} 3$ and $\mathrm{R}$, triterpene glycosides with two novel types of carbohydrate chains from the sea cucumber Cladolabes schmeltzii. Carbohydr Res 468:73-79

Silchenko AS, Kalinovsky AI, Avilov SA et al (2018b) Cladolosides $\mathrm{C}_{4}, \mathrm{D}_{1}, \mathrm{D}_{2}, \mathrm{M}, \mathrm{M}_{1}, \mathrm{M}^{2}, \mathrm{~N}$, and $\mathrm{Q}$, new triterpene glycosides with diverse carbohydrate chains from the sea cucumber Cladolabes schmeltzii. An uncommon 20,21,22,23,24,25,26,27-okta-nor- lanostane aglycone. The synergism of inhibitory action of non-toxic dose of the glycosides and radioactive irradiation on colony formation of HT-29 cancer cells. Carbohydr Res 468:36-44

Silva M, Rodriguez I, Barreiro A et al (2015) First report of ciguatoxins in two starfish species: Ophidiaster ophidianus and Marthasterias glacialis. Toxins (Basel) 7:3740-3757. https://doi.org/10.3390/ toxins 7093740

Singh N, Kumar R, Gupta S et al (2008) Antileishmanial activity in vitro and in vivo of constituents of sea cucumber Actinopyga lecanora. Parasitol Res 103:351-354. https://doi.org/10.1007/ s00436-008-0979-3

Soliman YA, Ibrahim AM, Tadros HRZ et al (2016) Antifouling and Antibacterial Activities of Marine Bioactive Compounds Extracted from some Red Sea Cucumber. Contemp Appl Sci 3:83-103

Song Y, Jin SJ, Cui LH et al (2013) Immunomodulatory effect of Stichopus japonicus acid mucopolysaccharide on experimental hepatocellular carcinoma in rats. Molecules 18:7179-7193. https:// doi.org/10.3390/molecules 18067179

Song J, Li T, Cheng X et al (2016) Sea cucumber peptides exert antiinflammatory activity through suppressing NF- $\mathrm{\kappa B}$ and MAPK and inducing HO-1 in RAW264.7 macrophages. Food Funct 7:27732779. https://doi.org/10.1039/c5fo01622c

Stöhr S, O'Hara TD, Thuy B (2012) Global diversity of brittle stars (Echinodermata: Ophiuroidea). PLoS One 7:e31940. https://doi. org/10.1371/journal.pone.0031940

Stonik VA (1986) Some terpenoid and steroid derivatives from echinoderms and sponges. Pure Appl Chem 58:423-436. https://doi. org/10.1351/pac198658030423

Stonik VA, Mal'tsev II, Elyakov GB (1982) The structure of Thelenotosides A and B from the Holothurian Theleonata ananas. Chem Nat Compd 18:590-593

Styles TJ (1970) Effect of Holothurin on Trypanosoma zewisi Infections in Rats. J Protozool 17:196-198

Sugawara T, Zaima N, Yamamoto A et al (2006) Isolation of Sphingoid Bases of Sea Cucumber Cerebrosides and Their Cytotoxicity against Human Colon Cancer Cells. Biosci Biotechnol Biochem 70:2906-2912. https://doi.org/10.1271/bbb.60318

Sun P, Liu BS, Yi YH et al (2007) A new cytotoxic lanostane-type triterpene glycoside from the sea cucumber Holothuria impatiens. Chem Biodivers 4:450-457. https://doi.org/10.1002/cbdv.200790037

Suwanmala J, Lu S, Tang Q et al (2016) Comparison of Antifatigue Activity of Five Sea Cucumber Species in a Mouse Model of Intense Exercise. J Food Nutr Res 4:12-19. https://doi.org/10.12691/jfnr-4-1-3

Tang HF, Yi Y, Li L et al (2005) Three new asterosaponins from the starfish Culcita novaeguineae and their bioactivity. Planta Med 71(5):458-463. https://doi.org/10.1055/s-2005-871215

Tang HF, Yi YH, Li L et al (2006) Asterosaponins from the starfish Culcita novaeguineae and their bioactivities. Fitoterapia 77:28-34. https://doi.org/10.1016/J.FITOTE.2005.07.009

Tang HF, Yi YH, Li L et al (2009) Bioactive Asterosaponins from the Starfish Culcita novaeguineae. J Nat Prod 68:337-341. https://doi. org/10.1021/np0401617

Telford MJ, Lowe CJ, Cameron CB et al (2014) Phylogenomic analysis of echinoderm class relationships supports Asterozoa. Proc R Soc B Biol Sci 281:20140479-20140479. https://doi.org/10.1098/ rspb.2014.0479

Thao NP, Cuong NX, Luyen BTT et al (2013) Anti-inflammatory asterosaponins from the starfish Astropecten monacanthus. J Nat Prod 76:1764-1770. https://doi.org/10.1021/np400492a

Thao NP, No JH, Luyen BTT et al (2014) Secondary metabolites from Vietnamese marine invertebrates with activity against Trypanosoma brucei and T. cruzi. Molecules 19:7869-7880. https://doi. org/10.3390/molecules 19067869

Thao NP, Luyen BTT, Kim EJ et al (2015a) Steroidal constituents from the edible sea urchin Diadema savignyi Michelin induce 
apoptosis in human cancer cells. J Med Food 18:45-53. https://doi org/10.1089/jmf.2013.3105

Thao NP, Luyen BTT, Koo JE et al (2015b) Anti-inflammatory components of the Vietnamese starfish Protoreaster nodosus. Biol Res 48:12. https://doi.org/10.1186/s40659-015-0002-2

Thiel M, Watling L (2015) Lifestyles and feeding biology. the natural history of the Crustacea, vol 2. Oxford Universiry Press, Oxford

Tian F, Zhang X, Tong Y et al (2005) PE, a new sulphated saponin from sea cucumber, exhibits anti-angiogenic and anti-tumor activities in vitro and in vivo. Cancer Biol Ther 4:874-882. https://doi. org/10.4161/cbt.4.8.1917

Tian F, Zhu C, Zhang X et al (2007) Philinopside E, a new sulfated saponin from sea cucumber, blocks the interaction between kinase insert domain-containing receptor (KDR) and avb3 integrin via binding to the extracellular domain of KDR. Mol Pharmacol 72:545-552. https://doi.org/10.1124/mol.107.036350.receptor

Turischev SN, Bolshakova GB, Sakandelidze OG et al (1991) Influence of complexes of holothurian triterpene glycosides on liver generation. Izv Akad Nauk SSSR, Ser Biol 2:306-310

Van Dyck S, Gerbaux P, Flammang P (2010) Qualitative and quantitative saponin contents in five sea cucumbers from the Indian ocean. Mar Drugs 8:173-189. https://doi.org/10.3390/md8010173

Vázquez MJ, Quiñoá E, Riguera R et al (1992) Santiagoside, the first asterosaponin from an antarctic starfish (Neosmilaster georgianus). Tetrahedron 48:6739-6746. https://doi.org/10.1016/ S0040-4020(01)80019-3

Vázquez MJ, Quindo E, Riguera R (1993) Helianthoside from Heliaster helianthus, an asterosaponin with a C3'- sulfated pyranose. Can J Chem 71:1174-1151

Vien LT, Ngoan BT, Hanh TTH et al (2017) Steroid glycosides from the starfish Pentaceraster gracilis. J Asian Nat Prod Res 19:474-480. https://doi.org/10.1080/10286020.2016.1235038

Vien LT, Hoang L, Hanh TTH et al (2018) Triterpene tetraglycosides from the sea cucumber Stichopus horrens. Nat Prod Res 32:10391043. https://doi.org/10.1080/14786419.2017.1378206

Wang W, Li F, Alam N et al (2002) New saponins from the starfish Certonardoa semiregularis. J Nat Prod 65:1649-1656. https://doi org/10.1021/np020234r

Wang W, Li F, Hong J et al (2003) Four New Saponins from the Starfish Certonardoa semiregularis. Chem Pharm Bull 51:435-439. https:// doi.org/10.1248/cpb.51.435

Wang W, Hong J, Lee C-O et al (2004a) Cytotoxic Sterols and Saponins from the Starfish Certonardoa semiregularis. J Nat Prod 67:584591. https://doi.org/10.1021/np030427u

Wang W, Jang H, Hong J et al (2004b) Additional cytotoxic sterols and saponins from the starfish Certonardoa semiregularis. J Nat Prod 67:1654-1660. https://doi.org/10.1021/np049869b

Wang W, Jang H, Hong J et al (2005) New Cytotoxic Sulphated Saponins from the Starfish Certonardoa semiregularis. Arch Pharmacal Res 28:285-289

Wang Z, Zhang H, Yuan W et al (2012) Antifungal nortriterpene and triterpene glycosides from the sea cucumber Apostichopus japonicus Selenka. Food Chem 132:295-300. https://doi.org/10.1016/J. FOODCHEM.2011.10.080

Wang XH, Zou ZR, Yi YH et al (2014) Variegatusides: New nonsulphated triterpene glycosides from the sea cucumber Stichopus variegates Semper. Mar Drugs 12:2004-2018. https://doi. org/10.3390/md12042004

Ward JA (1960) A further investigation on the swimming reaction of Stomphia coccinea. Master thesis. University of Washington

Wen Z, Zhu Z, Shen D et al (2004) Determination of asterosaponins in Asterias amurensis and Craspidaster hesperus with ultraviolet spectrophotometry. Fenxi Kexue Xuebao 20:592-594
Wen J, Hu C, Fan S (2010) Chemical composition and nutritional quality of sea cucumbers. J Sci Food Agric 90:2469-2474. https://doi. org/10.1002/jsfa.4108

Wen M, Fu X, Han X et al (2016) Sea cucumber saponin echinoside A (EA) stimulates hepatic fatty acid $\beta$-oxidation and suppresses fatty acid biosynthesis coupling in a diurnal pattern. J Nutr Sci Vitaminol (Tokyo) 62:170-177. https://doi.org/10.3177/jnsv.62.170

Wijesinghe WAJP, Vairappan CS, Jeo YJ (2015) Exploitation of Health Promoting Potentials of Edible Sea Cucumber (Holothuria edulis): Search of New Bioactive Components as Functional Ingredients. Int Proc Chem Biol Environ Eng 86:36-41. https://doi.org/10.7763/ IPCBEE

Wu J, Yi Y-H, Tang H-F et al (2006a) Nobilisides A - C, Three New Triterpene Glycosides from the Sea Cucumber Holothuria nobilis. Planta Med 72:932-935. https://doi.org/10.1055/s-2006-931603

Wu J, Yi Y, Tang H et al (2006b) Structure and Cytotoxicity of a New Lanostane-Type Triterpene Glycoside from the Sea Cucumber Holothuria hilla holothurians. Chem Biodivers 3:1249-1254

Wu J, Yi Y, Wu H et al (2007a) Studies on the in vitro antifungal and antitumor activities of nobiliside A from the sea cucumber holothuria nobilis Selenka. Zhongguo Yaolixue Tongbao 23:139-140

Wu J, Yi YH, Tang HF et al (2007b) Hillasides A and B, two new cytotoxic triterpene glycosides from the sea cucumber Holothuria hilla Lesson. J Asian Nat Prod Res 9:609-615. https://doi. org/10.1080/10286020600882676

Wu J, Zhang J, Ding P et al (2009a) Nobiliside C purified from Holothuria nobilis for use as antitumor agent. marinlit ID: A21616 (21787). Faming Zhuanli Shenqing Gongkai Shuomin

Wu J, Zhang J, Ding P et al (2009b) Anti-tumor compound hillaside a separated from Holothuria hilla CA151:181594. Marinlit ID: A22103 (22279) Faming Zhuanli Shenqing Gongkai Shuomin

Wu FJ, Xue Y, Liu XF et al (2014) The protective effect of eicosapentaenoic acid-enriched phospholipids from sea cucumber Cucumaria frondosa on oxidative stress in PC12 cells and SAMP8 mice. Neurochem Int 64:9-17. https://doi.org/10.1016/j. neuint.2013.10.015

Wu M, Xu L, Zhao L et al (2015) Structural analysis and anticoagulant activities of the novel sulphated fucan possessing a regular welldefined repeating unit from sea cucumber. Mar Drugs 13:20632084. https://doi.org/10.3390/md13042063

Xu J, Wang Y-M, Feng T-Y et al (2011) Isolation and anti-fatty liver activity of a novel cerebroside from the sea cucumber Acaudina molpadioides. Biosci Biotechnol Biochem 75:1466-1471. https:// doi.org/10.1271/bbb.110126

Yamada K, Tanabe K, Miyamoto T et al (2008) Isolation and Structure of a Monomethylated Ganglioside Possessing Neuritogenic Activity from the Ovary of the Sea Urchin Diadema setosum. Chem Pharm Bull 56:734-737. https://doi.org/10.1248/cpb.56.734

Yamanouchi $\mathrm{T}$ (1955) On the poisonous substance contained in Holothurians. Mar Biol Lab 4:183-203

Yang P, Collin P, Madden T et al (2003) Inhibition of proliferation of PC 3 cells by the branched-chain fatty acid, 12-methyltetradecanoic acid, is associated with inhibition of 5-lipoxygenase. Prostate 55:281-291. https://doi.org/10.1002/pros.10243

Yang S-W, Chan T-M, Buevich A et al (2007) Novel steroidal saponins, Sch 725737 and Sch 725739, from a marine starfish, Novodinia antillensis. Bioorg Med Chem Lett 17:5543-5547. https://doi. org/10.1016/j.bmcl.2007.08.025

Yang X-W, Chen X-Q, Dong G et al (2011) Isolation and structural characterisation of five new and 14 known metabolites from the commercial starfish Archaster typicus. Food Chem 124:1634-1638. https://doi.org/10.1016/j.foodchem.2010.08.033

Yano A, Abe A, Aizawa F et al (2013) The effect of eating sea cucumber jelly on Candida load in the oral cavity of elderly individuals in a 
nursing home. Mar Drugs 11:4993-5007. https://doi.org/10.3390/ md11124993

Yayli N, Findlay JA (1999) A triterpenoid saponin from Cucumaria frondosa. Phytochemistry 50:135-138. https://doi.org/10.1016/ S0031-9422(98)00463-4

Yi Y, Xu Q, Li L et al (2006) Philinopsides A and B , two new sulfated triterpene glycosides from the sea cucumber Pentacta quadrangularis. Helv Acta 89:54-63

Yi Y, Sun G, Li L et al (2008) Purification of triterpene saponin compound griseaside A from Holothuria grisea Selenka for cancer therapy and antitumor agent development. MarinLit ID: A20342 (20506). Faming Zhuanli Shenqing Gongkai Shuomin

Yibmantasiri P, Leahy DC, Busby BP et al (2012) Molecular basis for fungicidal action of neothyonidioside, a triterpene glycoside from the sea cucumber, Australostichopus mollis. Mol Biosyst 8:902. https://doi.org/10.1039/c2mb05426d

Yu S, Ye X, Huang H et al (2015) Bioactive Sulfated Saponins from Sea Cucumber Holothuria moebii. Planta Med 81:152-159. https://doi. org/10.1055/s-0034-1383404

Yuan W-H, Yi Y-H, Xue M et al (2008) Two Antifungal Active Triterpene Glycosides from Sea Cucumber Holothuria (Microthele) axiloga. Chin J Nat Med 6:105-108. https://doi.org/10.1016/ S1875-5364(09)60010-8

Yuan W-H, Yi Y, Tang H-F et al (2009a) Antifungal Triterpene Glycosides from the Sea Cucumber Bohadschia marmorata. Planta Med 75:168-173. https://doi.org/10.1055/s-0028-1088348

Yuan WH, Yi YH, Tan RX et al (2009b) Antifungal triterpene glycosides from the sea cucumber Holothuria (Microthele) axiloga. Planta Med 75:647-653. https://doi.org/10.1055/s-0029-1185381

Yun SH, Park ES, Shin SW et al (2012) Stichoposide C induces apoptosis through the generation of ceramide in leukemia and colorectal cancer cells and shows in vivo antitumor activity. Clin Cancer Res 18:5934-5948. https://doi.org/10.1158/1078-0432. CCR-12-0655

Yun SH, Sim EH, Han SH et al (2018) Holotoxin A1 induces apoptosis by activating acid sphyngomyelinase and neutral sphyngomyelinase in K562 and human primary leukemia cells. Mar Drugs 16:123

Zhan Y-C, Sun Y, Li W et al (2006) A new triterpene glycoside from Asterias rollentoni. J Asian Nat Prod Res 8:631-636. https://doi. org/10.1080/10286020500208626

Zhang J (2009) Antitumor effects of nobiliside B from sea cucumber Holothuria nobilis and its acetoxy compounds CA151:279085. Zhongguo Haiyang Yaowu 28:41-43

Zhang J-J, Zhu K-Q (2017) A novel antitumor compound nobiliside D isolated from sea cucumber (Holothuria nobilis Selenka). Exp Ther Med 14:1653-1658. https://doi.org/10.3892/etm.2017.4656
Zhang S-L, Li L, Yi Y-H et al (2006a) Philinopsides E and F, two new sulfated triterpene glycosides from the sea cucumber Pentacta quadrangularis. Nat Prod Res 20:399-407. https://doi. org/10.1080/14786410500185584

Zhang S-Y, Yi Y-H, Tang H-F (2006b) Cytotoxic sulfated triterpene glycosides from the sea cucumber Pseudocolochirus violaceus. Chem Biodivers 3:807-817. https://doi.org/10.1002/cbdv.200690083

Zhang S-Y, Yi Y-H, Tang H-F et al (2006c) Two new bioactive triterpene glycosides from the sea cucumber Pseudocolochirus violaceus. J Asian Nat Prod Res 8:1-8. https://doi.org/10.1080/ 10286020500034972

Zhang SY, Yi YH, Tang HF (2006d) Bioactive triterpene glycosides from the sea cucumber Holothuria fuscocinerea. J Nat Prod 69:1492-1495. https://doi.org/10.1021/np060106t

Zhang S-L, Li L, Sun P et al (2008) Lecanorosides A and B, two new triterpene glycosides from the sea cucumber Actinopyga lecanora. J Asian Nat Prod Res 10:1097-1103. doi:https://doi. org/10.1080/10286020701604813

Zhang B, Xue C, Hu X et al (2012) Dietary sea cucumber cerebroside alleviates orotic acid-induced excess hepatic adipopexis in rats. Lipids Health Dis 11(1). https://doi.org/10.1186/ 1476-511X-11-48

Zhang G, Ren H-H, Zhang Y-B et al (2013) Chemical constituents of the starfish Asterias rollestoni Bell. Biochem Syst Ecol 51:203-206. https://doi.org/10.1016/J.BSE.2013.08.031

Zhao Y, Li B, Dong S et al (2009) A novel ACE inhibitory peptide isolated from Acaudina molpadioidea hydrolysate. Peptides 30:10281033. https://doi.org/10.1016/j.peptides.2009.03.002

Zhao Q, Liu Z, Xue Y et al (2011) Ds-echinoside A, a new triterpene glycoside derived from sea cucumber, exhibits antimetastatic activity via the inhibition of NF-kB-dependent MMP-9 and VEGF expressions. J Zhejiang Univ Sci B 12:534-544. https://doi. org/10.1631/jzus.B1000217

Zhao Q, Xue Y, Wang J et al (2012) In vitro and in vivo anti-tumour activities of echinoside A and ds-echinoside A from Pearsonothuria graeffei. J Sci Food Agric 92:965-974. https://doi.org/10.1002/jsfa.4678

Zollo F, Finamore E, Minale L (1985) Starfish saponins XXIV. Two novel steroidal glycoside sulphates from the starfish Echinaster sepositus. Gazz Chim Ital 115:303-306

Zou Z-R, Yi Y-H, Wu H-M et al (2003) Intercedensides A-C, three new cytotoxic triterpene glycosides from the sea cucumber Mensamaria intercedens (Lampert). J Nat Prod 66:1055-1060. https://doi. org/10.1021/np030064y

Zou Z, Yi Y, Wu H et al (2005) Intercedensides D-I, cytotoxic triterpene glycosides from the sea cucumber Mensamaria intercedens Lampert. J Nat Prod 68:540-546. https://doi.org/10.1021/np040205b

Open Access This chapter is licensed under the terms of the Creative Commons Attribution 4.0 International License (http://creativecommons. org/licenses/by/4.0/), which permits use, sharing, adaptation, distribution and reproduction in any medium or format, as long as you give appropriate credit to the original author(s) and the source, provide a link to the Creative Commons license and indicate if changes were made.

The images or other third party material in this chapter are included in the chapter's Creative Commons license, unless indicated otherwise in a credit line to the material. If material is not included in the chapter's Creative Commons license and your intended use is not permitted by statutory regulation or exceeds the permitted use, you will need to obtain permission directly from the copyright holder.

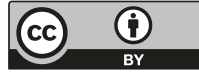

